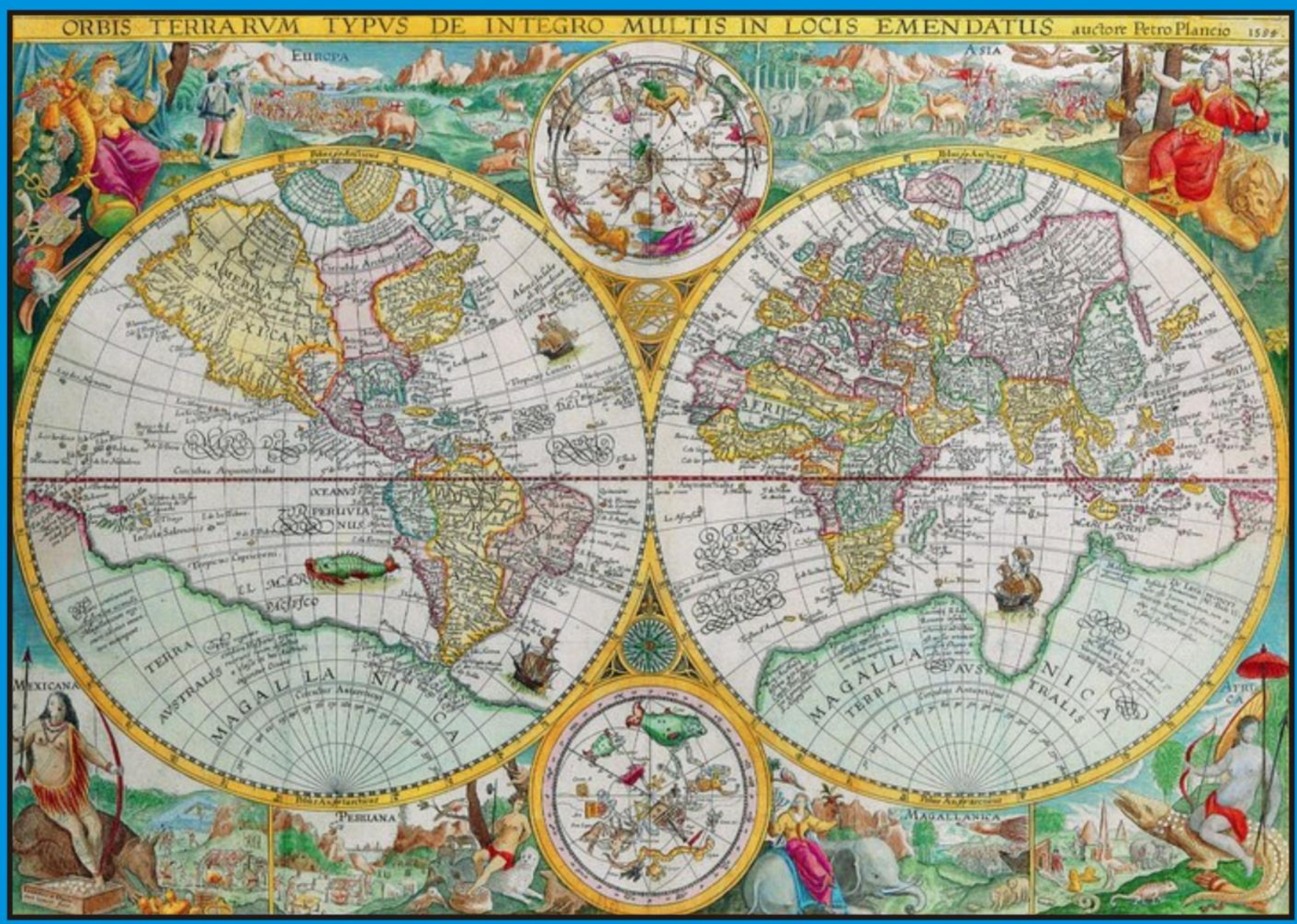

\title{
B Homepe:
}

Программы развития Дальнего Востока: критический анализ

Крестьянское хозяйство Нижнего Амура на рубеже XIX - XX вв.

Социальное самочувствие жителей юга Хабаровского края 
Peavoнaॉालmura

2014 ToM 1 No2

Электронный научный журнал regionalistica.org

ISSN 2313-0881

Периодичность выхода:

шесть номеров в год

Учредитель:

Федеральное государственное

бюджетное учреждение науки

Институт экономических

исследований

Дальневосточного отделения

Российской академии наук

(Хабаровск)

Журнал зарегистрирован

Федеральной службой

по надзору в сфрере связи,

информационных технологий и

массовых коммуникаций

11 марта 2014 г.

Свидетельство Эл № ФС77-57151

10

Авторы несут полную ответственность за подбор и изложение фактов, содержащихся в опубликованных материалах.

Высказываемые авторами взгляды могут не отражать точку зрения редакции.

Перепечатка материалов журнала допускается только по

согласованию с редакцией

- -

Адрес редакции: 680042, Хабаровск, ул. Тихоокеанская, 153

Телефон: +7 (4212) 225-404

E-mail: regionalistica@ecrin.ru

- $\square$

Дизайн, редактура, вёрстка:

В.Н. Украинский

В офрормлении обложки использована карта Петера Планциуса (1594)

\section{Редакционная коллегия}

\author{
Главный редактор: А.Н. Демьяненко, \\ д-р геогр. наук, профрессор
}

д-р геогр. наук А.В. Мошков (Владивосток, Россия)

д-р экон. наук С.Н. Найден (Хабаровск, Россия)

д-р экон. наук О.М. Прокапало (заместитель главного редактора, Хабаровск, Россия)

д-р экон. наук Ю.Д. Шмидт (Владивосток, Россия)

проф. Цунео Акаха (Монтерей, США)

проф. Винсент Ф. Галлуччи (Сиэтл, США)

канд. экон. наук А.П. Горюнов (Хабаровск, Россия) канд. полит. наук А.А. Киреев (Владивосток, Россия) канд. экон. наук В.С. Кузнецов (Владивосток, Россия) Л.А. Самохина (Хабаровск, Россия)

канд. экон. наук В.Н. Украинский (ответственный секретарь, Хабаровск, Россия)

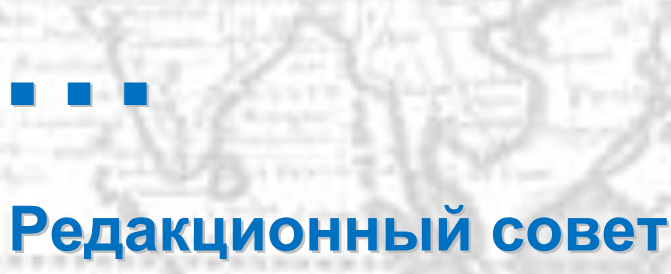

\section{Председатель: П.А. Минакир, академик РАН}

чл.-корр. РАН В.А. Крюков (Новосибирск, Россия)

чл.-корр. РАН В.Н. Лаженцев (Сыктывкар, Россия)

чл.-корр. РАН В.И. Суслов (Новосибирск, Россия)

чл.-корр. РАСХН А.С. Шелепа (Хабаровск, Россия)

д-р экон. наук С.Д. Валентей (Москва, Россия)

д-р экон. наук Н.В. Гальцева (Магадан, Россия)

д-р экон. наук С.В. Кузнецов (Санкт-Петербург, Россия)

д-р экон. наук Ю.Г. Лаврикова (Екатеринбург, Россия)

д-р экон. наук А.В. Островский (Москва, Россия)

д-р экон. наук В.E. Рохчин (Санкт-Петербург, Россия)

д-р экон. наук А.Н. Швецов (Москва, Россия)

д-р фрилос. наук А.М. Шкуркин (Хабаровск, Россия)

() Федеральное государственное бюджетное учреждение науки Институт экономических исследований Дальневосточного отделения Российской академии наук, 2014 


\section{СОДЕРЖАНИЕ}

Колонка главного редактора 5

Минакир П.А., Прокапало О.М.

Дальний Восток России: программные ожидания

Дятлова Л.А.

Эволюция крестьянского хозяйства на Нижнем Амуре: влияние природных и социально-экономических условий

Ли Е.Л., Логинова А.Г.

Южные районы Хабаровского края: оценка социального самочувствия населения 28

\section{СООБЩЕНИЯ $\rightarrow$}

Антонова Н.Е., Дёмина О.В., Захарченко Н.Г., Ломакина Н.В., Сухомиров Г.И. Оценка роли ресурсного сектора в экономике региона: пример Хабаровского края

Минакир П.А.

NEA Economic Integration: Russian Perspectives / Экономическая интеграция в CBA: российские перспективы

\section{НАУЧНЫЕ АРХИВЫ}

Волков Е.3.

На путях к плановому хозяйству (Первая Всероссийская Конференция по районированию)

\section{ХРОНИКА НАУЧНЫХ СОБЫТИЙ}

Ткаченко Г.Г.

Всероссийская научно-практическая конференция «Природно-ресурсный потенциал регионального развития Азиатской России»

Исаев А.Г.

Девятый совместный семинар КІЕР - ИЭИ ДВО РАН.

\section{РЕЦЕНЗИЯ}

\section{Ломакина Н.В.}

Не золотом единым... (Краткие заметки о книге Г.Ф. Скляровой

«Минерально-сырьевой сектор неметаллов Дальнего Востока и его роль для экономики региона»)

\section{IN MEMORIAM}

Памяти А.С. Шелепы. 


\section{CONTENTS}

The Column of Editor-in-Chief. 5

Minakir P.A., Prokapalo O.M.

Far East of Russia: Program Expectations.

Dyatlova L.A.

Evolution of Lower Amur River Peasant Economy: Influence of Natural and

Social-Economic Conditions.

Li E.L., Loginova A.G.

The Southern Areas of Khabarovsk Krai: Evaluation of Social Well-Being of the Population 28

\section{MESSAGES $\rightarrow$}

Antonova N.E., Dyomina O.V., Zakharchenko N.G., Lomakina N.V., Sukhomirov G.I.

Estimating the Resource Sector Role in Regional Economy: The Case of Khabarovsk Krai 42

Minakir P.A.

NEA Economic Integration: Russian Perspectives

\section{SCIENTIFIC ARCHIVES}

Volkov E.Z.

On Ways to a Planned Economy (First All-Russian Conference on Regionalization).

\section{SCIENTIFIC CHRONICLE $\rightarrow$}

Tkachenko G.G.

The All-Russian Scientific-Practical Conference «Natural Resource Potential of Regional

Development of the Asian Russia»

Isaev A.G.

9th KIEP - ERI Joint Seminar 99

\section{REVIEW}

Lomakina N.V.

Not Only Gold... (Short Notes about G.F. Sklyarova's Book «Raw Mineral Sector of Nonmetals of the Far East and Its Role for Region Economy»)

\section{IN MEMORIAM $\rightarrow$}

In Memory of A.S. Shelepa 


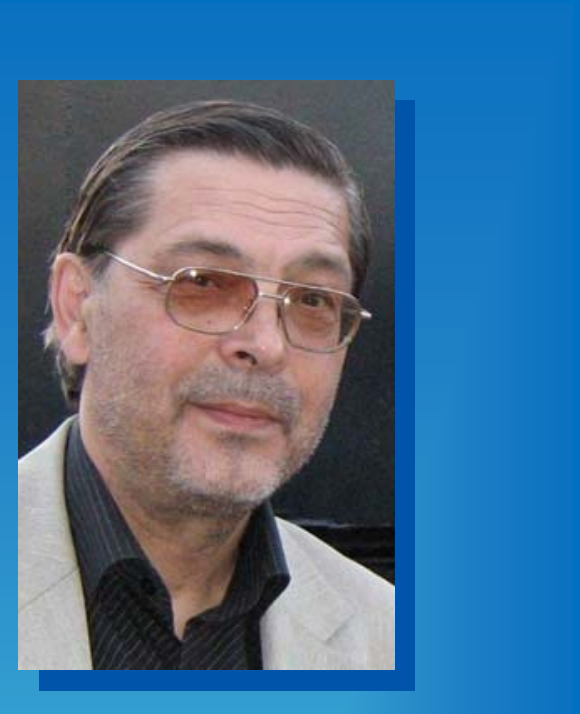

ДЕМЬЯНЕНКО

Александр Николаевич

Доктор географических наук, профессор, главный научный сотрудник

Институт экономических исследований ДВО РАН, ул. Тихоокеанская, 153,

Хабаровск, Россия, 680042

\section{DEMYANENKO}

Alexander

Nikolaevich

Doctor of geography, professor, chief researcher

Economic Research

Institute FEB RAS,

153, Tikhookeanskaya Street,

Khabarovsk, Russia, 680042

demyanenko@ecrin.ru

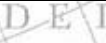 \\ КОЛОНКА ГЛАВНОГО РЕДАКТОРА $\rightarrow$}

Члены редколлегии и редакционного совета приложили немало усилий, чтобы, несмотря на время отпусков, в номере были качественные тексты. Надеюсь, что нам это удалось.

Так получилось, что при всём тематическом разнообразии практически все публикации, вошедшие в состав данного номера, посвящены одному региону - Дальнему Востоку. Конечно, в немалой степени такое положение дел обусловлено тем, что журнал находится в самом начале своего пути и поэтому ещё мало известен за пределами Дальнего Востока.

Открывающая номер статья П.А. Минакира и O.M. Прокапало «Дальний Восток России: программные ожидания» представляет собой образец неконъюнктурного анализа состояния и перспектив развития экономики региона. Статья Л.А. Дятловой - своего рода экзотика: в последние годы работы, выполненные в жанре историкогеографического анализа экономики конкретного региона, практически исчезли со страниц научной периодики. Тем любопытнее ознакомиться с результатами такого рода анализа применительно к Нижнему Амуру конца XIX - начала ХХ вв.

Надеюсь, что читатели обратят внимание на работу П.А. Минакира «NEA Economic Integration: Russian Perspectives» не только потому, что она написана на английском языке (напомню, что журнал имеет два рабочих языка - русский и английский), но главным образом потому, что в ней представлен объективный взгляд на проблемы экономической интеграции в Северо-Восточной Азии.

Зрелость науки, как мне представляется, в значительной мере определяется интересом исследователей к истории этой науки. А в истории региональных исследований (в том числе и отечественной регионалистики) есть много чего полезного. Чему свидетельством может служить работа, вошедшая в новую рубрику «Научные архивы».

Кстати, в географии тоже есть много чего полезного. Увы, но только за последние недели я узнал много нового для себя именно в географии. И ладно, когда г-жа Псаки не знает, что Астраханская область не граничит с Украиной. Но когда центральные телевизионные каналы мне сообщают, что есть в нашем отечестве такой народ как чукоты, а нанайцы, оказывается, проживают в Арктической зоне, то впору задаться вопросом: географию в школе учили или как? 


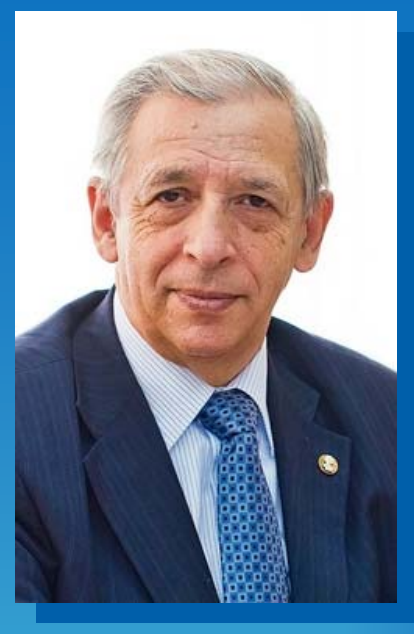

\section{МИНАКИР}

Павел

Александрович

Академик, профрессор, доктор экономических наук директор

Институт экономических исследований ДВО РАН, ул. Тихоокеанская, 153, Хабаровск, Россия, 680042

\section{MINAKIR}

Pavel

Aleksandrovich

Academician, professor, doctor of economics, director Economic Research Institute FEB RAS, 153, Tikhookeanskaya Street, Khabarovsk, Russia, 680042

minakir@ecrin.ru

\section{УДК $332+338$}

\section{ДАЛЬНИЙ ВОСТОК РОССИИ: ПРОГРАММНЫЕ ОЖИДАНИЯ}

В статье дана оценка выполнения крупномасштабных программ и стратегий долгосрочного развития Дальнего Востока России, реализуемых начиная с середины 1980-х гг. Показано, что нечёткое и расплывчатое формулирование целевых критериев является общей и главной проблемой для всех программных документов. Делается вывод, что целью долгосрочного развития региона в большей степени должно быть не увеличение объёма инвестиций, а выращивание эффективных экономических институтов и формирование среды, благоприятной для их функционирования.

Программа, критерии развития, регион, экономический pocm

\section{FAR EAST OF RUSSIA: PROGRAM EXPECTATIONS}

The article offers an assessment of the performance of largescale programs and strategies of long-term development of the Russian Far East since the middle 1980s. It shows that the unclear and indistinct formulation of target criteria is the general and main problem for all program documents. It concludes that rather than growth of investment, cultivation of effective economic institutions and formation of an environment conducive to their survival should be the main goal of the region's long-term development.

Program, criteria of development, region, economic growth
(C) Минакир П.А.,

Прокапало О.М., 2014 


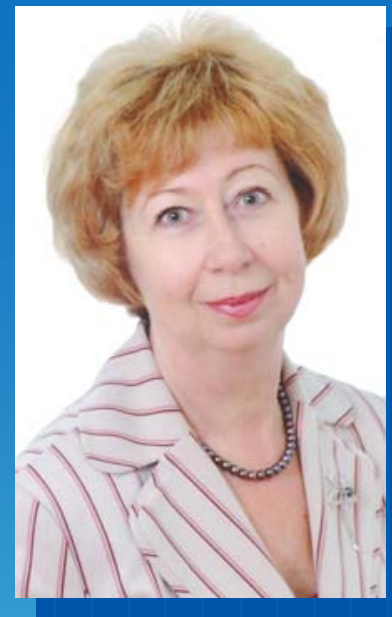

ПРОКАПАЛО

\section{Ольга}

Михайловна

Доктор экономических наук учёный секретарь

Институт экономических исследований ДВО РАН, ул. Тихоокеанская, 153, Хабаровск, Россия, 680042

\section{PROKAPALO Olga \\ Mikhailovna}

Doctor of economics, scientific secretary

Economic Research Institute FEB RAS, 153, Tikhookeanskaya Street, Khabarovsk, Russia, 680042

prokapalo@ecrin.ru
Активное государственное регулирование с использованием крупномасштабных программ и стратегий началось на Дальнем Востоке с середины 1980-х гг. При этом ставка была сделана с самого начала на использование экономических методов регулирования с целью достижения преимущественно экономических целей. Это отличает стратегии и программы развития этого периода от регулирования в эпоху колонизации Дальнего Востока и его военной индустриализации. С середины 1980-х гг. можно насчитать несколько различных по масштабу и срокам стратегических и программных документов, направленных на развитие российского Дальнего Востока (табл. 1).

Все эти документы объединялись общей идеологией (они были направлены на решение общерегиональных проблем, которые невозможно было решить в рамках ведомственного планирования и управления), структурой (решение проблем отраслевых комплексов и социальных задач отдельных территорий), технологией разработки (суммирование инвестиционных намерений и социальных задач территорий и отраслей), а также характером преследуемых целей (наращивание экономического потенциала, повышение темпов роста экономики, усиление инфраструктуры, рост населения).

Большого успеха эти программы не имели ни по одному из целевых критериев. Собственно говоря, расплывчатость как раз целевых критериев являлась главной и общей проблемой для всех программ и стратегий [1-3]. К настоящему времени отсутствует чёткое определение понятия «экономическое и социальное развитие», а также ясное отражение его в определённом показателе. Фактически таким показателем являются темпы роста ВРП. Это отражено и в самой последней версии государственной программы от 15 апреля 2014 г., в которой в качестве первого целевого индикатора указан «индекс роста ВРП».

Некоторые основания для такого упорного желания «ускорения» действительно имелись в течение довольно длительного времени. В 1998-2007 гг. темп роста экономики Дальнего Востока отставал от среднероссийского темпа роста в 1,16 раза $(163,2 \% \text { и } 190,4 \% \text {, соответственно })^{1}$. Ещё больший по величине разрыв был характерен для периода 1950-1960 гг. (1,34 раза $)^{2}$, когда также развитие Дальнего Востока пытались организовать в рамках программ распре-

${ }^{1}$ Рассчитано по: Основные показатели системы национальных счетов 1998-2005 гг. М., 2005; Регионы России. Социально-экономические показатели. 2008. М., 2008.

${ }^{2}$ Рассчитано по: Дальний Восток России: экономическое обозрение. Изд. 2. Хабаровск: РИОТИП, 1995. С. 56. 
Таблица 1

Программно-стратегические документы по развитию Дальнего Востока РФ

\begin{tabular}{|c|c|c|c|}
\hline № & Название и год принятия & $\begin{array}{c}\text { Сроки } \\
\text { реализации }\end{array}$ & Статус \\
\hline 1 & $\begin{array}{l}\text { Долговременная государственная программа ком- } \\
\text { плексного развития производительных сил Даль- } \\
\text { невосточного экономического района, Бурятской } \\
\text { АССР и Читинской области на период до } 2000 \text { года }\end{array}$ & $1987-2000$ & $\begin{array}{l}\text { Постановление ЦК КПСС } \\
\text { и Совета Министров } \\
\text { СССР от } 19 \text { августа } \\
1987 \text { г. № } 958\end{array}$ \\
\hline 2 & $\begin{array}{l}\text { ФЦП «Экономическое и социальное развитие } \\
\text { Дальнего Востока и Забайкалья на 1996-2005» }\end{array}$ & $1996-2005$ & $\begin{array}{l}\text { Постановление Прави- } \\
\text { тельства РФ от } 15 \text { апреля } \\
1996 \text { г. № } 480\end{array}$ \\
\hline 3 & $\begin{array}{l}\text { ФЦП «Экономическое и социальное развитие } \\
\text { Дальнего Востока и Забайкалья на 1996-2005 и до } \\
2010 \text { года» }\end{array}$ & $2002-2010$ & $\begin{array}{l}\text { Постановление Прави- } \\
\text { тельства РФ от } 19 \text { марта } \\
2002 \text { г. № } 169\end{array}$ \\
\hline 4 & $\begin{array}{l}\text { ФЦП «Экономическое и социальное развитие } \\
\text { Дальнего Востока и Забайкалья на период до } \\
2013 \text { года» }\end{array}$ & $2008-2013$ & $\begin{array}{l}\text { Постановление Прави- } \\
\text { тельства РФ от } 21 \text { ноября } \\
2007 \text { г. № } 801\end{array}$ \\
\hline 5 & $\begin{array}{l}\text { Стратегия социально-экономического развития } \\
\text { Дальнего Востока и Байкальского региона на пе- } \\
\text { риод до } 2025 \text { г. }\end{array}$ & $2014-2025$ & $\begin{array}{l}\text { Распоряжение Прави- } \\
\text { тельства РФ от } 28 \text { декаб- } \\
\text { ря } 2009 \text { г. № } 2094-p\end{array}$ \\
\hline 6 & $\begin{array}{l}\text { Государственная программа РФ «Социально- } \\
\text { экономическое развитие Дальнего Востока и Бай- } \\
\text { кальского региона» }\end{array}$ & $2014-2025$ & $\begin{array}{l}\text { Распоряжение Прави- } \\
\text { тельства РФ от } 29 \text { марта } \\
2013 \text { г. № 466-р }\end{array}$ \\
\hline 7 & $\begin{array}{l}\text { ФЦП «Экономическое и социальное развитие } \\
\text { Дальнего Востока и Байкальского региона на пе- } \\
\text { риод до } 2018 \text { года» }\end{array}$ & $2014-2018$ & $\begin{array}{l}\text { Постановление Прави- } \\
\text { тельства РФ от } 6 \text { декабря } \\
2013 \text { г. № } 1128\end{array}$ \\
\hline 8 & $\begin{array}{l}\text { Государственная программа РФ «Социально- } \\
\text { экономическое развитие Дальнего Востока и Бай- } \\
\text { кальского региона» (новая редакция) }\end{array}$ & $2014-2025$ & $\begin{array}{l}\text { Постановление Прави- } \\
\text { тельства РФ от } 15 \text { апреля } \\
2014 \text { г. № } 308\end{array}$ \\
\hline
\end{tabular}

деления ресурсов по сугубо экономическим критериям.

Вообще, экономического роста в отдельно взятом регионе можно достичь разными путями (стратегиями): 1) стабильным приростом объёма применяемых ресурсов (при данном значении коэффициентов временных лагов); 2) стабильным приростом производительности применяемых ресурсов; 3) комбинацией первых двух условий. Выбор зависит, как правило, от характера взаимосвязи прироста объёма применяемых ресурсов и прироста выпуска продукции, а также от длительности временно́го лага между приростом капи- тальных ресурсов и приростом выпуска продукции. Дальний Восток с точки зрения этих двух характеристик является маргинальным регионом, то есть таким, в котором значение инвестиционного мультипликатора невелико, а временной лаг чрезмерно длителен. Поэтому наиболее важное значение имело соблюдение условия стабильного и значительного по размерам прироста применяемых капитальных и оборотных ресурсов.

Но до 2007 г. именно это условие хронически не выполнялось. А отдача от крупных инвестиционных негосударственных вложений («сахалинские проекты») 
начала проявляться только в самом конце этого периода. Вялость в выделении государственных инвестиций для развития региона объяснялась не только и не столько напряжённостью федерального бюджета, сколько фактическим отсутствием национальных приоритетов в развитии Дальнего Востока. Считалось, что вполне достаточно использовать стандартные либеральнорыночные критерии и механизмы в распределении и использовании ресурсов. Это предположение верно при стандартном значении инвестиционного мультипликатора и средних величинах временно́го лага, но неверно при замыкающих значениях соотношения «затраты - результаты» и чрезмерной длительности временно́го лага.

Ситуация изменилась к 2008 г. Вопервых, появилась ясная и важная внеэкономическая задача, которая должна была быть реализована именно на Дальнем Востоке, - подготовка к саммиту АТЭС-2012. Во-вторых, вполне очевидной стала необходимость создания условий для масштабного выхода сырьевых монополий на новые рынки - рынки стран СевероВосточной Азии. Без этого удержать, а тем более увеличить уровень доходов от эксплуатации и экспорта природных ресурсов, которые в 2012 г. составляли 56\% доходов федерального бюджета $Р \Phi^{1}$, в перспективе невозможно.

На период 2008-2013 гг. была утверждена новая государственная программа развития Дальнего Востока и Забайкалья. Фактически она состояла из двух программ - программы развития города Владивостока, как центра проведения саммита АТЭС-2012, и «всего остального». При этом по стоимости программа подготовки АТЭС-2012 составляла $2 / 3$ общего объёма финансирования ФЦП. В этот же период на Дальнем Востоке и в Восточной Сибири закладывалась новая ресурсная база экспортного назначения, основу которой со-

\footnotetext{
Рассчитано по: http://www.gks.ru/free_doc/new_ site/finans/fin21.htm
}

ставили углеводородные месторождения Сахалинского шельфа, Республики Саха (Якутии) и Иркутской области. Ещё одной составной частью означенной федеральной программы являлось создание магистральной экспортопроводящей сети, в состав которой входили нефтепровод «Восточная Сибирь - Тихий океан», газопроводные системы «Сахалин - СВА» и «Восточная Сибирь - СВА», «усиленные» БАМ и Транссиб, Транскорейская железная дорога, электроэнергетические мосты «Дальний Восток - Китай» и модернизированные морские порты Приморского и Хабаровского краёв.

Эта программа стала первой после программ конца 1960-х - начала 1970-х гг., в которой чётко преследовались вполне определённые цели национального уровня. В значительной степени благодаря этому она стала и первой успешной программой за почти 25-тилетний период. При этом следует ясно понимать, что «успех», определяется не тем или иным значением статистических индикаторов, а достижением вполне определённых, «вещественных» целей - построенными и реконструированными производственными, социальными и инфраструктурными объектами, которые обеспечивают определённый количественный и/или качественный результат. В случае Дальнего Востока успех программы определяется завершением строительства запланированного комплекса сооружений, предназначенных для саммита АТЭС в г. Владивосток, а также созданием комплекса инфраструктурных объектов для обеспечения транзита углеводородов, металлов и электроэнергии в страны CВА.

Реализация инфраструктурных и сырьевых проектов потребовала существенного увеличения объёмов инвестиций. Темп роста инвестиций в основной капитал в целом по региону начал опережать среднероссийскую динамику уже с 2001 г., но наиболее очевидными «ножницы» в инвестициях стали после 2008 г. (рис. 1). 


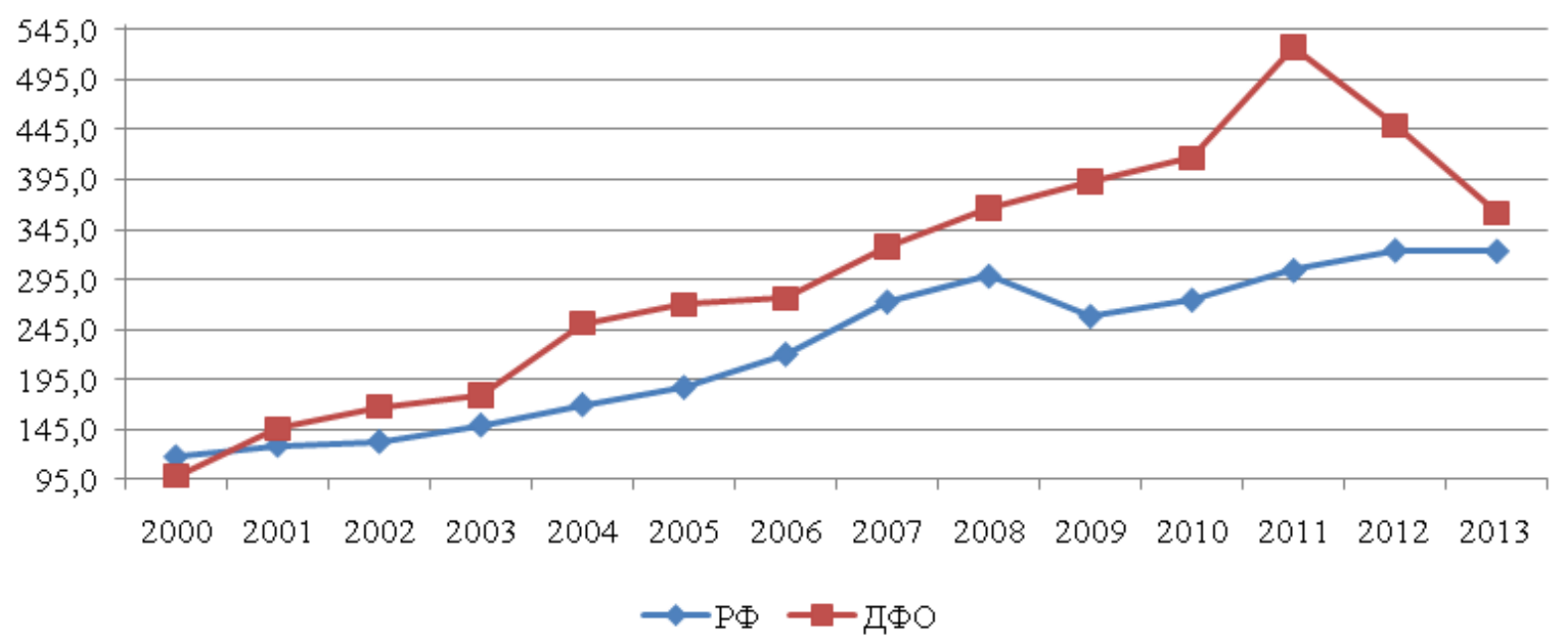

Puc. 1. Индекс инвестиций в основной капитал, \% (1999 г. = 100\%)

В 2009-2011 гг. инвестиции в основной капитал на Дальнем Востоке составили более $8 \%$ общего объёма инвестиций в российской экономике. И именно в этот период оказались ликвидированы «ножницы» в темпах роста между среднероссийскими и дальневосточными индексами: среднегодовой темп роста дальневосточной экономики составил $112,5 \%$ против $110,2 \%$ в целом по экономике России.

Впрочем, это не было прямым результатом «инвестиционной накачки». Инвестиционный мультипликатор на Дальнем Востоке остаётся по-прежнему маргинальным, если иметь в виду как средние по РФ показатели, так и ситуацию в основных «инвестиционно-передовых» регионах. Капиталоёмкость производства 1 рубля ВРП по ДФО составляла в 2011 г. 37 копеек против 24 копеек в среднем по РФ. Выше капиталоёмкость была только в Калужской области (40 копеек) и Красноярском крае (57 копеек) ${ }^{1}$. Выравнивание темпов роста ВРП произошло главным образом в результате лучшего «прохождения» Дальним Востоком острой фазы кризиса в 2009 г. (рис. 2). Конечно, на это повлияли

\footnotetext{
${ }^{1}$ Рассчитано по: http://www.gks.ru/bgd/regl/b12_14p/ IssWWW.exe/Stg/d03/24-01.htm; http://www.gks.ru/ bgd/regl/b12_14p/IssWWW.exe/Stg/d01/11-01.htm
}

и сохранявшиеся в 2009 г. инвестиции, но, в ещё большей степени, высокий удельный вес добывающих производств при сохранившейся сравнительно благоприятной конъюнктуре на сырьевых рынках CBA.

На Дальнем Востоке доля добычи полезных ископаемых вместе с рыболовством составляет $29,5 \%$ ВРП против $11,6 \%$ по РФ, а в совокупности со строительством, обеспечивающим освоение инвестиций $^{2}$, и транспортом, обеспечивающим экспорт ресурсов на внешние рынки, $54,7 \%$ ВРП против 28,5\% в среднем по России.

В период 2008-2013 гг. целью программы развития региона являлось создание условий для выхода российских сырьевых монополий на новые рынки. Это была «новая редакция» колониальной политики второй половины XIX в. Была ли достигнута эта цель? В некоторой степени предпосылки закрепления на новых рынках очевидны. Причём не только российских корпораций национального уровня, но и дальневосточных фирм.

\footnotetext{
${ }^{2}$ На Дальнем Востоке почти 73\% инвестиций - это вложения в жилые и производственные здания и сооружения (против 58\% по РФ).
} 


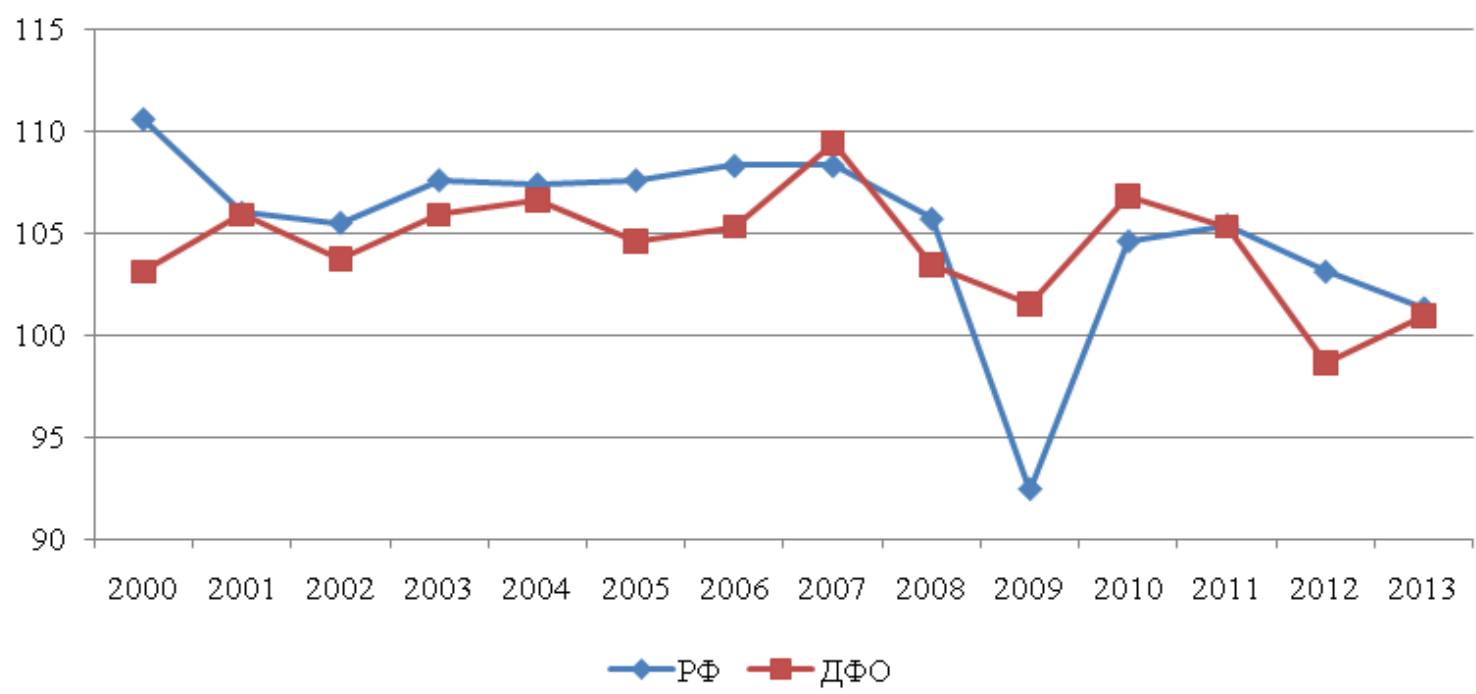

Puc. 2. Темпы роста ВРП, \% к предыдущему году

В апреле 2013 г. была утверждена новая государственная программа развития Дальнего Востока и Байкальского региона. В этой программе не было чётких задач экономического или внеэкономического характера, но вплоть до 2018 г. предусматривались ещё бо́льшие затраты госбюджета, чем в предыдущей программе: в 2008-2013 гг. средства госбюджета составляли 463 млрд рублей, а на 20142018 гг. запланировано было более 800 млрд рублей. Впрочем, с учётом инфляции такое увеличение не кажется слишком большим, хотя условия формирования бюджета значительно ужесточились. Проблема заключается в том, какие задачи должны были решаться за счёт этих денег и за счёт мультиплицируемых ими частных инвестиций. Программа 2013 г. и утвержденная в декабре 2012 г. Стратегия развития региона идеологически основывались на сформулированном в послании Президента Федеральному собранию тезисе: «Разворот России к Тихому океану, динамичное развитие всех наших восточных территорий не только откроет нам новые возможности в экономике, новые горизонты, но и даст дополнительные инструменты для проведения активной внешней политики» [4]. Хорошо прослеживается пре- емственность этого тезиса с тезисом о превращении Дальнего Востока в «окно в АТР», который содержался в речи, произнесённой М.С. Горбачевым в 1986 г. во Владивостоке. Но важно не это, а то, что этот тезис превращает достаточно чёткую формулировку национальной цели (создание инфраструктуры для выхода на новые рынки) в расплывчатый геополитический лозунг. Конкретная задача создания экспортопроводящей магистральной инфраструктуры и увеличения экспорта экономически эффективных ресурсов и продукции трансформируется в довольно загадочный литературный оборот: «развитие восточных территорий».

Всё было бы просто, если бы существовали строго однозначные зависимости: «национальная цель - развитие восточных территорий» и «инвестиционные проекты - развитие восточных территорий». Тогда можно было бы сказать, что наращивание инвестиций само по себе является целью программы. Неявно именно это предположение и «зашито» в идее новой программы ${ }^{1}$. Но можно ли так сказать? Действи-

\footnotetext{
1 «Мы уже приняли решение по льготной ставке налога на прибыль и ряду других налогов для новых инвестпроектов на Дальнем Востоке. Считаю
} 
тельно ли увеличение инвестиций равнозначно экономическому и социальному развитию региона?

Конечно, главная проблема заключается в том, что понимается под словосочетанием «развитие региона». Если исходить из формулируемых целей различных программ, здесь могут быть обнаружены разные варианты ответа: темпы роста ВРП, производство ВРП на душу населения, прирост численности населения, увеличение объёма инвестиций, увеличение доходов бюджета, изменение структуры экономической деятельности (то есть диверсификация производства и экспорта). Любой из этих показателей может улучшаться и реально улучшается со временем. Вопрос заключается в том, насколько важно (исходя из каких-либо соображений) форсировать эти улучшения любой ценой в конкретном регионе?

Действительно, сравнительный анализ динамики ВРП на Дальнем Востоке и в среднем по РФ (рис. 3) свидетельствует о том, что «развитие региона», если под этим понимать темпы роста ВРП, остаётся неудовлетворительным. Разрыв со среднероссийскими темпами не исчезает. Однако это лишь подтверждает вышеупомянутую маргинальность зависимости между приростом капитальных ресурсов и приростом выпуска. Ухудшение сравнительной динамики макроэкономических показателей в регионе началось после 2011 г., когда снижение темпов роста ВРП стало сопровождаться ухудшением динамики инвестиций в основной капитал. В 2010-2013 гг. среднегодовой прирост ВРП в ДФО составлял 1,6\% против 3,25\% в среднем по РФ, а среднегодовой темп роста инвестиций составил 95,4\% против 108,6\% в среднем по РФ (табл. 2). В предыдущий период (2007-2011 гг.) Дальний Восток входил в число регионов-лидеров по темпам при-

целесообразным распространить этот режим на всю Восточную Сибирь, включая Красноярский край и Республику Хакасия» [4]. роста инвестиций в основной капитал, с ежегодными темпами прироста в среднем $13,8 \%$, лучший показатель был только у Южного федерального округа $(15,1 \%)$. По сравнению с этими цифрами ситуация 2012-2013 гг. действительно выглядит удручающей. Здесь следует иметь в виду, что инвестиционный бум был обеспечен средствами, вложенными в строительство крупных инфраструктурных проектов госкорпораций, и бюджетными инвестициями, в том числе в строительство объектов саммита АТЭС-2012, а также нефтепровода ВСТО. После завершения строительства инфраструктурных мега-проектов объём инвестиций, естественно, стал снижаться.

Однако следует обратить внимание и на то, что темпы роста промышленного производства остаются в регионе более высокими, чем средние по стране, это же относится к грузообороту на транспорте и экспорту, объём которого в 2000-2012 гг. увеличился в 2,2 раза против 1,7 раз в целом для экономики РФ. Именно эти индикаторы отражают реальный потенциал региональной экономики, созданный, помимо прочего, и предшествовавшими инвестициями в транспортный, добывающий и инфраструктурный комплексы.

С точки зрения генерирования доходов бюджетов (доля налоговых и неналоговых доходов в ВРП) дальневосточные регионы практически не отличаются от наиболее экономически развитых субъектов РФ. Это относится и к общей бюджетной обеспеченности (табл. 3). То есть проблема заключается не в той или иной производительности экономики с точки зрения налоговых поступлений, а в том, что собственные источники доходов в регионах недостаточны для финансирования их мандатов. Но это - общероссийская, а не специфически дальневосточная проблема.

Принципиальная неясность относительно целей развития Дальнего Востока отражается в нечёткости формулировки са- 


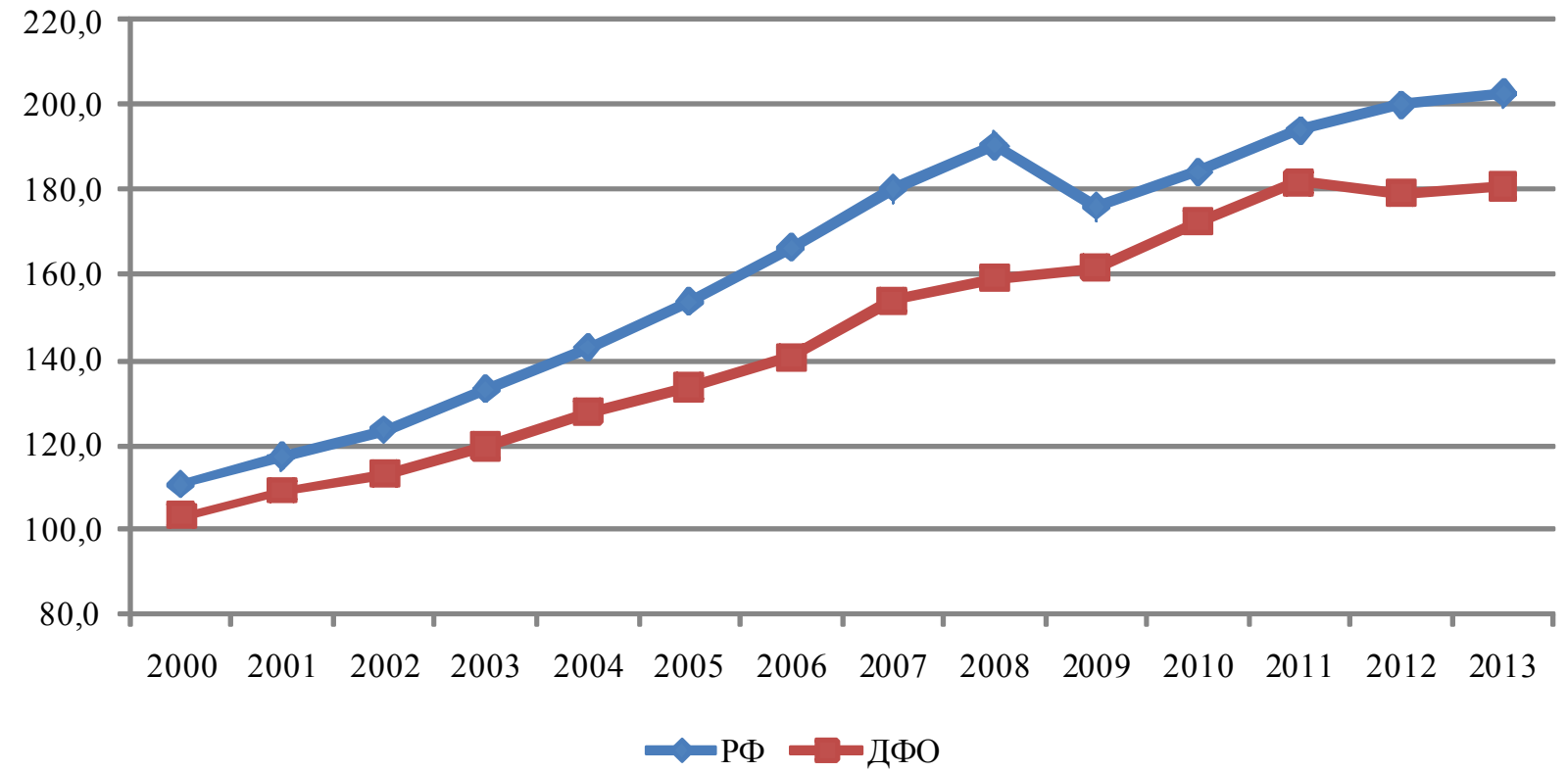

Puc. 3. Темпы роста ВРП, \% (1999 г. = 100\%)

Таблица 2

Показатели развития экономики, \% к предыдущему году

\begin{tabular}{|l|c|c|c|c|c|c|}
\hline \multirow{2}{*}{\multicolumn{1}{|c|}{ Показатели }} & \multicolumn{2}{c|}{2011} & \multicolumn{2}{c|}{2012} & \multicolumn{2}{c|}{2013} \\
\cline { 2 - 7 } & РФ & ДФО & РФ & ДФО & РФ & ДФО \\
\hline $\begin{array}{l}\text { Валовой внутренний (регио- } \\
\text { нальный) продукт }\end{array}$ & 105,4 & 105,3 & 103,1 & 98,6 & 101,3 & $100,9 *$ \\
\hline $\begin{array}{l}\text { Индекс промышленного произ- } \\
\text { водства ** }\end{array}$ & 104,7 & 108,8 & 102,6 & 103,1 & 100,3 & 103,0 \\
\hline Инвестиции в основной капитал & 110,8 & 126,5 & 106,6 & 85,2 & 99,8 & 80,5 \\
\hline $\begin{array}{l}\text { Грузооборот по всем видам } \\
\text { транспорта }\end{array}$ & 103,4 & 105,0 & 101,7 & 107,2 & 100,5 & 108,4 \\
\hline Экспорт & 130,2 & 135,6 & 101,7 & 102,9 & 98,8 & $106,7 *$ \\
\hline $\begin{array}{l}\text { Реальные денежные доходы } \\
\text { населения }\end{array}$ & 101,1 & 101,5 & 105,8 & 104,9 & 103,7 & 104,7 \\
\hline
\end{tabular}

Примечания: * предварительные данные;

** агрегированный индекс производства по видам деятельности «Добыча полезных ископаемых», «Обрабатывающие производства» и «Производство и распределение электроэнергии, газа и воды».

Источники: материалы официального сайта Федеральной службы государственной статистики (www.gks.ru); Регионы России. Социально-экономические показатели. 2013. Стат. сб. / Росстат. М., 2013. 990 с.; Социальноэкономическое положение Дальневосточного федерального округа в 2013 г. Стат. сб. / Росстат. М., 2014. 84 с.; Основные показатели социально-экономического положения регионов ДФО в 2013 г., I часть: Стат. бюлл. / Территориальный орган Федеральной службы государственной статистики по Хабаровскому краю. Хабаровск, 2014. 58 c. 
Таблица 3

Бюджетные индикаторы по субъектам РФ (на 1 января 2013 г.)

\begin{tabular}{|c|c|c|c|}
\hline & $\begin{array}{c}\text { Общие доходы на } \\
\text { душу населения, } \\
\text { тыс. рублей }\end{array}$ & $\begin{array}{c}\text { Доля безвозмездных } \\
\text { поступлений в дохо- } \\
\text { дах населения, \% }\end{array}$ & $\begin{array}{c}\text { Налоговые и нена- } \\
\text { логовые доходы, } \\
\text { копеек на } 1 \text { рубль } \\
\text { ВРП (2010 г.) }\end{array}$ \\
\hline В среднем по РФ & 56,2 & 20,1 & 15,6 \\
\hline В среднем по ДФО & 90,6 & 32,0 & 15,2 \\
\hline Якутия & 146,7 & 39,9 & 18,9 \\
\hline Приморский край & 50,6 & 23,4 & 13,5 \\
\hline Хабаровский край & 68,0 & 21,9 & 17,3 \\
\hline Сахалинская область & 158,2 & 9,3 & 14,1 \\
\hline Краснодарский край & 244,9 & 29,6 & 14,9 \\
\hline Ростовская область & 152,5 & 23,5 & 15,0 \\
\hline г. Москва & 127,7 & 5,9 & 15,6 \\
\hline г. Санкт-Петербург & 75,5 & 12,2 & 15,1 \\
\hline Башкоторстан & 35,7 & 17,6 & 14,1 \\
\hline Татарстан & 55,1 & 22,3 & 13,1 \\
\hline Калужская область & 49,9 & 15,1 & 18,4 \\
\hline Московская область & 64,3 & 15,4 & 18,6 \\
\hline Калининградская область & 51,8 & 31,6 & 15,1 \\
\hline Нижегородская область & 39,6 & 15,9 & 15,4 \\
\hline Самарская область & 45,9 & 11,6 & 16,3 \\
\hline Свердловская область & 47,2 & 8,9 & 15,7 \\
\hline Новосибирская область & 47,6 & 17,5 & 18,8 \\
\hline Красноярский край & 66,5 & 15,1 & 12,8 \\
\hline
\end{tabular}

Источники: составлено на основании данных Министерства финансов Российской Федерации (http://info.minfin.ru/subj_analitics.php) и Федеральной службы государственной статистики (http://www.gks.ru/bgd/regl/b12_14p/IssWWW.exe/Stg/d03/24-04.htm).

мой программы. Фактически речь идёт о долговременном «довороте» геополитической и геоэкономической стратегии России в направлении Тихого океана с целью повышения национальной макроэкономической устойчивости и минимизации рисков односторонней зависимости от рынков Европы. Естественно, что подобный «доворот» представляет собой чрезвычайно дли- тельную и очень дорогую программу. Дальний Восток занимает определённое место в этой программе как территориальная площадка для размещения инфраструктуры доступа к рынкам АТР, а также источник ресурсов для поддержания и наращивания уровня торговых и инвестиционных взаимодействий. Соответственно, в долговременной государственной про- 
грамме геостратегического «доворота» должен присутствовать фрагмент, посвящённый собственно Дальнему Востоку, то есть задачи, которые необходимо решать относительно региона, должны быть «встроены» в общую систему стратегических целей.

На деле же наблюдается обратная картина: формулируется программа «развития Дальнего Востока», в которую встроены важнейшие общегосударственные задачи геостратегического характера. Это как раз и приводит к чрезвычайной размытости целей и задач, их предельной всеобщности и практической невозможности количественного определения и контроля. В полной мере это проявилось и в последней версии государственной программы развития Дальнего Востока и Байкальского региона, которая утверждена соответствующим постановлением Правительства РФ 15 апреля 2014 г.

Цель программы формулируется следующим образом - «ускоренное развитие Дальнего Востока и Байкальского региона; улучшение социально-демографической ситуации на территории Дальнего Востока и Байкальского региона» ${ }^{1}$. А под «ускоренным развитием» по-прежнему подразумевается темп роста макроэкономических индикаторов: индекс роста валового регионального продукта; индекс роста инвестиций в основной капитал; повышение доли региона в доходах консолидированного бюджета РФ; повышение доли обрабатывающих производств в структуре ВРП региона; рост численности населения (что равнозначно росту числа рабочих мест).

Многослойность проблемы отражается в сложной конструкции самой программы и сложной структуре задач, которые предполагается решить. Во-первых, государственная программа содержит «в себе» ещё и Федеральную целевую программу, временной горизонт которой -

\footnotetext{
${ }^{1}$ Cм.: http://minvostokrazvitia.ru/upload/iblock/6ed/gp 34.pdf
}

2018 г. Во-вторых, макроэкономические цели государственной программы разбиваются на две группы задач: 1) региональные задачи (улучшение транспортной доступности и повышение качества жизни населения региона, в том числе за счёт повышения мобильности жителей) и 2) федеральные / корпоративные задачи (обеспечение транзита грузов). Для решения этих задач предполагается в период 20142020 гг. (причина, по которой опущен период 2021-2025 гг., в самой программе не раскрывается) выделить из государственного бюджета около 346 млрд рублей (почти 50 млрд рублей в среднем в год). Из них около 224 млрд рублей предполагается выделить в 2014-2017 гг. в рамках ФЦП (то есть в среднем по 56 млрд рублей в год). Ещё почти 120 млрд рублей в среднем в год составит, как предполагается, финансирование проектов программы за счёт внебюджетных источников. То есть в первые 4 года планируемая сумма инвестиций из разных источников составляет почти 175 млрд рублей в год. Практически такие же ресурсы привлекались для решения задач в рамках предыдущей программы (ФЦП на 2008-2013 гг.) - 165 млрд рублей в среднем в год. Конечно, учитывая довольно высокую инфляцию, реальный объём ресурсов окажется меньше, чем в предыдущей программе.

Следовательно, тенденции макроэкономического развития самого региона вряд ли претерпят сколько-нибудь заметные изменения. Впрочем, изменения возможны в случае, если ресурсная ситуация всё-таки будет существенно скорректирована с учётом происходящих в настоящее время кардинальных геополитических сдвигов на китайском направлении и в перспективе переориентации ресурсного экспорта с европейского на китайский рынок. Это, конечно, потребует значительного увеличения объёма инвестиций в усиление транзитной инфраструктуры. Только по предварительным оценкам, затраты на эти цели в ближайшие 4-5 лет составят не менее 
50-60 млрд долларов США, то есть порядка 2 трлн рублей, что значительно превышает вышеприведённые параметры финансирования программы развития Дальнего Востока и Байкальского региона.

Такое увеличение объёма финансовых ресурсов, связанное с развитием корпоративных экспортных проектов, безусловно, будет сильным положительным внешним шоком для макроэкономической динамики в регионе. Однако проблему собственно развития региона это всё равно не решит, так как инвестиционный шок окажет сравнительно кратковременное воздействие на экономическую динамику, что подтверждается и опытом реализации предшествовавших программ регионального развития. Если оставить за скобками корпоративный экспортный сегмент, развитие которого будет на длительное время обеспечено инвестиционной накачкой в транзитную и добывающую инфраструктуру, и говорить о собственно региональном развитии (то есть о формировании инфраструктуры доступа к коммунальным благам и общественным фондам, транспортной инфраструктуры, обеспечивающей мобильность граждан, условий и механизмов генерации доходов в рамках регионального бизнес-сообщества, создании комфортной бизнес-среды, формировании режима открытой экономики в регионах концентрированной экономической деятельности), то акцент придётся делать не на инвестиционной накачке, а на выращивании эффективных экономических институтов и формировании среды, благоприятной для их функционирования.

\section{Список литературы}

1. Минакир П.А., Прокапало О.М. Государственная программа РФ «Социальноэкономическое развитие Дальнего Востока и Байкальского региона» // Пространственная экономика. 2013. № 1. С. 103-122.

2. Минакир П.А., Прокапало О.М. Дальний Восток: реальные стратегии и мнимые про- граммы // Вестник ДВО РАН. 2007. № 5. C. $13-21$.

3. Минакир П.А., Прокапало О.М. Региональная экономическая динамика. Дальний Восток. Хабаровск: ДВО РАН, 2010. 304 с.

4. Послание Президента Федеральному Собранию от 12 декабря 2013 года. URL: http://www.kremlin.ru/news/19825 (дата обращения: 02.01.2014).

\section{References}

1. Minakir P.A., Prokapalo O.M. The Russian Federation State Program «Socio-Economic Development of the Far East and the Baikal Region». Prostranstvennaya economika [Spatial Economics]. 2013. No. 1. Pp. 103-122. (In Russian)

2. Minakir P.A., Prokapalo O.M. The Far East: Real Strategies and Imaginary Programs. Vestnik Dalnevostochnogo otdelenia Rossiiskoy academii nauk [Vestnik of the Far East Branch of the Russian Academy of Sciences]. 2007. No. 5. Pp. 1321. (In Russian)

3. Minakir P.A., Prokapalo O.M. Regional Economic Dynamics. The Russian Far East. Khabarovsk, 2010. 304 p. (In Russian)

4. Presidential Address to the Federal Assembly of December 12, 2013. Available at: http://www.kremlin.ru/news/19825 (accessed 2 January 2014). (In Russian)

\section{Для циитирования:}

Минакир П.А., Прокапало О.М. Дальний Восток России: программные ожидания // Регионалистика. 2014. Т. 1. № 2. С. 6-16.

For citing:

Minakir P.A., Prokapalo O.M. Far East of Russia: Program Expectations. Regionalistica [Regionalistics]. 2014. Vol. 1. No. 2. Pp. 616. (In Russian) 


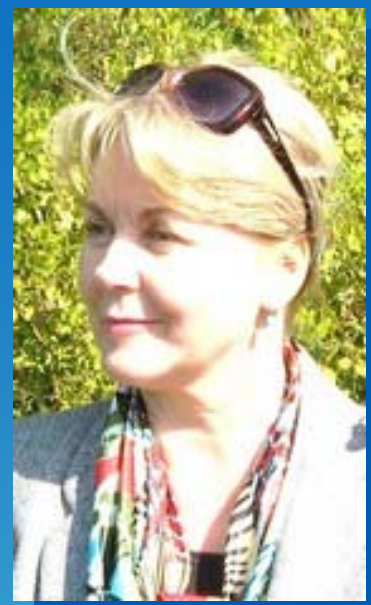

\section{ДЯТЛОВА}

\section{Любовь}

Александровна

Кандидат географрических

наук, доцент

Тихоокеанский государственный университет, ул. Тихоокеанская, 136, Хабаровск, Россия, 680035

\section{DYATLOVA}

\section{Lyubov}

Aleksandrovna

Ph.D. in geography, associate professor Pacific National University, 136, Tikhookeanskaya Street, Khabarovsk, Russia, 680035

dyatlovala@pochta.ru

\section{УДК 913}

\section{ЭВОЛЮЦИЯ КРЕСТЬЯНСКОГО ХОЗЯЙСТВА НА НИЖНЕМ АМУРЕ: ВЛИЯНИЕ ПРИРОДНЫХ И СОЦИАЛЬНО- ЭКОНОМИЧЕСКИХ УСЛОВИЙ}

В статье на основе данных массовых обследований исследуется специфика эволюции крестьянских хозяйств Нижнего Амура на рубеже XIX-XX вв. Особое внимание уделено влиянию природно-ресурсных факторов на формирование организационного плана крестьянского хозяйства и на организацию рыночного пространства в пределах Нижне-Амурского района.

Крестьянское хозяйство, Нижний Амур, колонизачия, организационный план, рыночные системы, рыбные промыслы

-

\section{EVOLUTION OF LOWER AMUR RIVER PEASANT ECONOMY: INFLUENCE OF NATURAL AND SOCIAL-ECONOMIC CONDITIONS}

Using data from mass surveys of peasant communities on the Lower Amur river, the article examines the specifics of these communities' evolution in the late XIX - early XX centuries. Special attention is paid to the influence of environmental and resource factors on organizational plan of peasant economy and on the structure of market space in the Lower Amur region.

Peasant economy, Lower Amur region, colonization, organizational plan, market systems, fisheries

(C) Дятлова Л.А., 2014 


\section{Введение}

Среди первоочередных мер аграрного реформирования в современной России провозглашается создание условий для возрождения традиционного для нашей страны трудового крестьянского хозяйства, что, по нашему мнению, придаёт особую актуальность изучению и использованию исторического опыта реформирования сельской экономики, ибо решение современных проблем (как общегосударственных, так и региональных) невозможно без ясного представления о генезисе и путях эволюции крестьянского хозяйства.

В конечном счёте, анализ региональных аспектов эволюции крестьянских хозяйств, методов их поддержки предоставляет дополнительные возможности для выяснения сущности механизмов функционирования и саморазвития сельской экономики на региональном (локальном) уровне.

В предлагаемой статье автор предпринял попытку выявить специфику эволюции крестьянских хозяйств Нижнего Амура в конце XIX - первой четверти $\mathrm{XX}$ вв. и определить, насколько это возможно, область применения исторического опыта для возрождения трудового крестьянского хозяйства в качестве фактора устойчивого развития экономики региона.

При этом автор, отдавая себе отчёт относительно сложности и многоаспектности проблемы, в рамках данной статьи позволил себе ограничиться изучением следующих вопросов:

- основные направления эволюции крестьянского хозяйства Нижнего Амура в конце XIX - начале XX вв.;

- влияние местных природных и социально-экономических факторов на организационный план крестьянского промыслового хозяйства.

В качестве информационной базы исследования послужили главным образом материалы сельскохозяйственных перепи- сей 1916, 1917 и 1923 гг. [18; 26], а также результаты массовых обследований крестьянских хозяйств Приморской области, проведённых в период 1906-1912 гг. под руководством А. Меньщикова [19-23].

\section{Некоторые соображения теоретико-методологического характера}

Сразу же оговоримся: автор не ставил перед собой задачи дать исчерпывающий обзор теории крестьянского хозяйства, равно как и методологических подходов к его исследованию. Тем более что авторская позиция по эти вопросам была достаточно детально изложена в целом ряде предшествующих публикаций ${ }^{1}$. Поэтому ограничимся лишь следующими замечаниями самого общего характера.

Во-первых, в трудах отечественных экономистов-аграрников, среди которых необходимо упомянуть А.П. Людоговского, А.С. Ермолова, А.И. Чупрова, В.Е. Постникова, Н. Каблукова, А.Ф. Фортунатова и др., ещё на рубеже XIX-XX вв. последовательно ставились и анализировались вопросы о природе крестьянского хозяйства и предпринимались попытки объяснить причины устойчивости крестьянского хозяйства по сравнению с другими типами хозяйств.

Во-вторых, уже в первой четверти $\mathrm{XX}$ в. в рамках организационно-производственной школы (А.Н. Челинцев, А.В. Чаянов, Н.П. Макаров и др.) крестьянское хозяйство рассматривалось с организационной точки зрения. То есть фактически был разработан принципиально новый методологический подход к исследованию крестьянского хозяйства. Суть этого подхода заключалась в том, что крестьянское хозяйство рассматривалось как сложная социально-экономическая система, вписанная в природный и политический контекст. Тем самым в центре иссле-

\footnotetext{
${ }^{1}$ См., например: [8-9; 11-13].
} 
довательского фокуса оказывались такие вопросы, как: Каково внутреннее строение крестьянского хозяйства? Каким образом в нём достигается соразмерность частей? Каковы формы его реакции на воздействия внешних природных и экономических факторов?

Всё вышесказанное имеет отношение к экономике крестьянского хозяйства, но есть ещё один аспект, который не так часто привлекает внимание исследователей, а именно: историко-географический.

В книге «Этногенез и биосфера Земли» Л.Н. Гумилёв писал: «взаимодействие человечества с природой постоянно...» [5, с. 17]. Прервём на время фразу исследователя (мы вернёмся к ней чуть позже) и отметим, что из всех видов хозяйственной деятельности наиболее тесное взаимодействие человека и природы наблюдается в сельскохозяйственном производстве. То же самое следует сказать о крестьянском хозяйстве, которое в течение всего своего существования постоянно имеет дело с природными ресурсами (земельными, лесными, водными, минеральными).

Поэтому не случайно многие исследователи, когда-либо занимавшиеся проблемами сельской экономики в целом и трудового крестьянского хозяйства в частности, в числе факторов, обуславливающих характер сельскохозяйственного производства и определяющих образ жизни и род занятий крестьянина, на первое место ставят природные факторы.

Аналогичного мнения придерживался и Ф. Бродель: «как много определяет соотношение климата, почвы и рельефа, от него зависят такие важнейшие вещи, как характер земледелия, тип жилища, еда, образ жизни, средства передвижения, источники энергии» $[4, \text { с. } 43]^{1}$.

Вернёмся к Л.Н. Гумилёву и просле-

\footnotetext{
${ }^{1}$ Подробнее авторская позиция относительно методологии «геоистории» Ф. Броделя и её места в исследовании пространственных проявлений экономической деятельности изложена в [10].
}

дим его мысль далее: взаимодействие природы не только постоянно, но и «крайне вариабельно и в пространстве и во времени» [5, с. 17]. Объясняется это «разнообразием» и «динамичностью» природы Земли. Следовательно, продолжает Л.Н. Гумилёв, «в разных географических регионах и в разные эпохи люди и природные комплексы (ландшафты и геобиоценозы) взаимодействуют по-разному» [5, с. 17].

В развёрнутой форме эту мысль применительно к хозяйственной деятельности, в том числе и сельскохозяйственному производству, формулирует А.Г. Исаченко: «Каждый ландшафт заключает индивидуальный комплекс природных ресурсов: водных, минеральных, биологических. Тем самым он обладает определённым хозяйственным и экологическим потенциалом... Ландшафт - это такой природный комплекс, в отношении которого можно ставить вопрос о едином направлении хозяйственного развития» [14, с. 123]. О том же, в сущности, но касательно трудового крестьянского хозяйства, ещё в начале $\mathrm{XX}$ в. писал и профессор А.Ф. Фортунатов. После многолетних исследований крестьянских хозяйств европейской России он приходит к убеждению, что «разные соотношения различных сельскохозяйственных угодий накладывают особый отпечаток на крестьянские хозяйства, меняют характер занятий населения и способствуют формированию типов крестьянских хозяйств, присущих только данной территории» [27, с. 5]. К такому же выводу пришёл исследователь дальневосточного крестьянства начала XX в. А. Меньщиков: «Природные явления глубоко входят в толщу крестьянской жизни и должны быть признаны главным стимулом в развитии русского крестьянского хозяйства». Но далее отмечает, что «по мере повышения культурного уровня страны хозяйство интенсифицируется, и значение природных условий падает, заслоняясь другими культурноисторическими факторами» [19, c. XXXIII]. 
Таким образом, многообразие ландшафтов (что значит - многообразие сочетаний природных условий и ресурсов) обуславливает разнообразие крестьянских хозяйств различной производственной направленности.

Однако не всегда наличие какоголибо природного ресурса в достаточном количестве определяет ориентацию хозяйственной деятельности в соответствующем направлении. В этом случае нельзя не согласиться с Н.Н. Баранским, который отмечал, что «природа создаёт только постоянные условия и возможности... Реализация этих возможностей определяется всецело общественно-историческими моментами и может весьма сильно варьировать» [2, с. 87].

Таким образом, определённое сочетание территориально изменчивых факторов, включающее помимо природных факторы экономического и социального характера, обуславливает формирование территориально-отраслевой структуры того или иного социально-экономического района. И, в конечном счёте, определяет характер сельскохозяйственного производства и влияет на организационный план крестьянского хозяйства. Остаётся добавить, что степень влияния различных групп факторов неодинакова и зависит от степени экономической зрелости региона.

Отметим, что сам по себе сюжет «региональные варианты крестьянского хозяйства» не нов. В частности, хорошо известны работы, выполненные в начале XX в. П.А. Соколовским, В.Е. Постниковым и другими авторами ${ }^{1}$. Такой подход даёт возможность, рассматривая крестьянское хозяйство через призму условий конкретного природно-хозяйственного района, проникнуть в сущность трудового крестьянского хозяйства, исследовать его

\footnotetext{
${ }^{1}$ Нет необходимости перечислять все работы, посвящённые данной теме, так как их достаточно полная сводка дана в монографии А.В. Чаянова «Бюджетные исследования» [28].
}

коренные черты, установить территориальные особенности и определить его место в социально-экономической системе региона.

Однако практически все эти исследования начала XX в. рассматривали крестьянское хозяйство в весьма узких географических рамках, зачастую в пределах одного-двух уездов, реже - губернии. К тому же эти исследования были выполнены исключительно по материалам обследований отдельных регионов Европейской России, а значит, при условии большего или меньшего постоянства территориальных факторов, и с этой точки зрения они носили ограниченный характер, так как прослеживали эволюцию крестьянского хозяйства лишь во времени, но не в пространстве.

А. Меньщиков объяснял этот факт тем, что «в Европейской России отстоявшееся в течение многих веков население отыскало в местных природных особенностях объекты приложения труда и развивает свою деятельность в зависимости от целого ряда инертных, малоподвижных, издавна установившихся экономических причин» $[19$, с. 33]. Иначе говоря, упомянутые работы оценивали результат влияния территориальных факторов, но, как правило, не показывали сам процесс приспособления трудового крестьянского хозяйства к новым условиям, а значит, не могли определить степень его адаптационных возможностей.

Хотя в истории России можно обнаружить достаточно много примеров, иллюстрирующих процесс адаптации русских крестьян к новым условиям и появление в результате новых многочисленных вариантов хозяйственной жизни. Это неудивительно, поскольку вся история России связана с колонизацией, которая каждый раз сопровождалась приспособлением к особенностям территории. Именно в колонизации В.О. Ключевский видел главную причину хозяйственного многообразия: «При каждом таком передвижении оно [славянское население - Л.Д.] становилось 
под действие новых условий, вытекавших как из физических особенностей новозанятого края, так и из новых внешних отношений, какие завязывались на новых местах. Эти местные особенности и отношения при каждом новом размещении народа сообщали народной жизни особое направление, особый склад и характер» [16, c. 20].

\section{Специфика крестьянской колонизации Нижнего Амура}

Опыт колонизации Нижнего Амура на рубеже XIX-XX вв. есть яркое подтверждение того, как непривычные условия зачастую заставляли русского крестьянина-землепашца ломать строй своего хозяйства и решать совершенно новые задачи. Таким образом, исследование опыта крестьянской колонизации в этом регионе позволяет проследить эволюцию крестьянского хозяйства во времени и пространстве. Такую возможность даёт соединение количественного анализа материалов массовых обследований крестьянских хозяйств 1906-1909, 1917 и 1923 гг. с работами, посвящёнными социально-экономическому развитию Дальнего Востока. Этот подход позволяет выявить качественные изменения в традиционном хозяйстве русского крестьянина-землепашца под влиянием специфических природных и социально-экономических условий Нижнего Амура и трансформацию его в промысловое крестьянское хозяйство. Сразу же отметим, что изменения организационного плана в том или ином направлении, которые происходили под влиянием внешних по отношению крестьянскому хозяйству условий конкретного социально-экономического района, как правило, не сопровождались изменением самой природы крестьянского хозяйства, утратой присущих ему отличительных свойств ${ }^{1}$.

\footnotetext{
${ }^{1}$ Впрочем, это не означает, что отсутствовали исключения из общего правила. В частности, ещё в
}

В рамках этого же исследовательского подхода мы получаем возможность проверить, в какой мере преимущества традиционного для европейской России трудового крестьянского хозяйства сохранялись в специфических природных и социальноэкономических условиях Нижнего Амура, и, в частности, выявить степень адаптационных возможностей этого хозяйства ${ }^{2}$.

По-нашему мнению, в эволюции нижнеамурского трудового крестьянского хозяйства на рубеже XIX-XX вв., можно выделить два этапа: первый - от начала освоения (середина XIX в.) до 90-х гг. XIX в., второй - c конца XIX в. до начала советизации.

До 1890-х гг. колонизация на Нижнем Амуре носила крестьянский, преимущественно земледельческий характер, хотя природные условия здесь в большей степени благоприятствовали занятию промыслами (прежде всего рыбными), нежели земледелием. Однако на первых порах крестьяне сочетали промыслы с сельским хозяйством, более того, земледелие имело существенное значение в организационном плане, на что указывает средняя величина посева на одно крестьянское хозяйство (56 десятин в начале 1890-х гг.) и наличие достаточно большого количества сельскохозяйственного инвентаря (почти 30 плугов на 100 хозяйств). Величина посева свидетельствует и о том, что земледелие носило товарный характер, чему в немалой степени способствовали высокие цены на сельскохозяйственную продукцию, дос-

конце XIX в. исследователи Приамурского края отмечали «огилячивание» части русских крестьянских хозяйств. Другой пример: из среды русских крестьян-переселенцев вышел ряд рыбопромышленников Нижнего Амура. Однако всё это - единичные факты.

2 Отметим, что способность адаптироваться к новым условиям не только природного, но и экономического характера, а также максимально использовать их для удовлетворения своих внутренних потребностей, не утрачивая при этом коренных качеств, является, на наш взгляд, уникальным свойством трудового крестьянского хозяйства. 
тавляемую морем из европейской части России ${ }^{1}$.

Несмотря на богатство рыбных ресурсов (главным образом лососевых пород) $)^{2}$, добываемая рыба в основном потреблялась самим крестьянским хозяйством, и лишь часть её закупалась военным ведомством, поставлялась на золотые прииски и в сахалинские тюрьмы.

Другие виды природных ресурсов, за исключением пушного зверя, на начальном этапе эволюции крестьянского хозяйства оказались невостребованными из-за отсутствия соответствующих рынков сбыта. Тем не менее, общей тенденцией в эволюции крестьянского хозяйства на первом этапе являлось усиление роли промыслов: происходило превращение земледельческого крестьянского хозяйства в промысловое (прежде всего рыбопромысловое), по преимуществу мелкотоварное.

Открытие в начале 1890-х гг. японского рынка ${ }^{3}$, а после русско-японской войны - российского и западноевропейского рынков привело к тому, что усилия государства и переселенцев направляются на освоение богатейших природных ресурсов региона. И хотя рыбные ресурсы попрежнему играли заглавную роль, начиная с конца XIX в. происходит постепенное расширение круга природных ресурсов, используемых крестьянскими хозяйствами в своей деятельности ${ }^{4}$.

\footnotetext{
${ }^{1}$ По мнению А. Меньщикова, одного из наиболее авторитетных специалистов в области экономики крестьянского хозяйства, величина посева, превышавшая 4 десятины, свидетельствовала об исключительно товарном ведении хозяйства.

${ }^{2}$ В.К. Бражников, посетивший по заданию председателя Управления Государственных имуществ низовье Амура, восторженно отозвался об этих местах: «В отношении рыбных богатств описываемая местность вряд ли уступает какой-либо другой в нашем отечестве и по количеству и по ценности промысловых пород» [3, с. 37].

3 Подробно история открытия японского рынка для рыбных промыслов Нижнего Амура изложена в следующих работах: $[1 ; 3 ; 25]$.

${ }^{4}$ В частности, организация регулярного пароходст-
}

Нижне-Амурский район ${ }^{5}$ превратился в один из крупнейших рыбопромысловых районов России. Согласно статистическим данным Управления Государственных имуществ, добыча рыбы в пределах Николаевского промыслового района за 1898-1907 гг. увеличилась с 4,2 до 12,5 млн штук, то есть в 3 раза [3, с. 8].

O масштабах крестьянских рыбных промыслов свидетельствуют следующие данные: в 1909 г. только крестьянамистарожилами этого района было поймано лососевых на сумму 650565 рублей, тогда как в Ярославской губернии - всего 29 тыс. рублей, в Сыр-Дарьинской и Самаркандской областях - более 497 тыс. рублей, на Байкале (1906 г.) - 393860 рублей [21, с. 429].

Влияние рынка обусловило активизацию как промышленной, так и крестьянской промысловой колонизации Нижнего Амура. По данным М. Колобова, «в первые пять лет после Русско-Японской войны здесь образовалось 22 сельских поселения, к началу первой мировой войны - 29, за время революции - ещё 5» [17, с. 35].

Более того, крестьянская колонизация изменила свой в прошлом земледельческо-промысловый характер и переросла в промысловую ${ }^{6}$. Выразилось это в том, что крестьянские поселения на Нижнем Амуре становятся типичными промысловыми, специализировавшимися в основном на добыче рыбы (главным образом, лососевых пород). В качестве доказательства приведём данные А. Меньщикова [21]:

ва на Амуре вызвала к жизни развитие лесных промыслов.

5 Нижне-Амурский (экономический) район рассматривается нами как один из входивших в систему экономических районов, установленных А.Н. Демьяненко для южной части Дальнего Востока на начало $\mathrm{XX}$ в. [6; 7].

6 Здесь сошлёмся на А. Ярмоша, который определял промысловую колонизацию как «устройство в крае промысловых хозяйств... Она [промысловая колонизация - Л.Д.] одним своим концом связывается с промышленной колонизацией, а другим - с сельскохозяйственной» [29, с. 61] 
удельный вес хозяйств с промыслами составлял более $90 \%$, из них более $75 \%$ занимались крупными рыбными промыслами. Ещё одним доказательством служи и то, что $13,7 \%$ крестьянских хозяйств не имели посева, что совсем не означало (как то было в европейской части России) превращение их в сельский пролетариат.

Трансформации крестьянского промыслового хозяйства из мелкотоварного в товарное способствовали не столько объёмы рыбных ресурсов и относительная легкость организации лова, сколько растущий спрос и выгодная рыночная конъюнктура. Что делало рыбный промысел экономически более целесообразным по сравнению с трудоёмким и в то же время менее доходным земледелием.

Вполне естественно, что в этих условиях крестьянские хозяйства быстро перешли из режима самообеспечения, который был для них характерен на начальном этапе колонизации, в рыночный режим и приобрели товарный характер. Достаточно веским доказательством этого могут служить данные 1907 г. по Нижнему Амуру: из 1981210 штук лососевых, добытых крестьянами для себя было оставлено лишь 316728 штук, т.е. 16\% [24, с. 887].

Однако всё вышесказанное вовсе не означало, что крестьянство утратило связь с землей. Так, $86,3 \%$ хозяйств сохранили небольшой (в среднем не более 1 десятины) посев $[15$, с. 244$]$ и использовали его в основном для выращивания огородных культур, часть которых (картофель, капусту) сбывали на проходящие пароходы. Зерновые культуры из структуры посева исчезли.

Объясняется это тем, что хлеб, фураж и другие недостающие в хозяйстве продукты крестьяне стали покупать на рынке, так как доходы от рыбных промыслов давали им такую возможность. Так, например, средний доход на семью от крупных рыбных промыслов в селе Пермское (находилось на территории современного
Комсомольска-на-Амуре) составлял более 550 рублей $^{1}$, в то время как цены на пшеницу колебались в диапазоне 90 копеек 1 рубль, на овес - 70-80 копеек, на картофель - 20-30 копеек за пуд [21, с. 282]. Доходы от рыбных промыслов позволяли крестьянам часть денежных средств направлять на улучшение своего хозяйства.

Таким образом, рыбный промысел расширял и разнообразил связь крестьянского хозяйства с рынком, поднимал уровень зажиточности крестьян, создавал условия для развития и, тем самым, делал это хозяйство более устойчивым, а значит жизнеспособным. В то же время, сохраняя для себя небольшой посев, крестьянин не просто обеспечивал себя огородными культурами, но оставлял для себя возможность вернуться в режим самообеспечения на случай, если внешние условия станут менее благоприятными, и связь с рынком перестанет носить стабильный характер или же совсем прервётся.

Подтверждением этому является ситуация, сложившаяся в начале 1920-х гг., когда по политическим причинам произошло сжатие рынка. В ответ крестьянин изменил организационный план своего хозяйства так, что соотношение товарной и нетоварной составляющих изменилось в сторону увеличения последней. Это выразилось в сокращении объёма добычи рыбы, увеличении посева до 0,6 десятины на хозяйство (против 0,3 десятины в 1910 г.), а также введении в его структуру зерновых и фуражных культур.

Считаем необходимым обратить внимание на следующий момент: несмотря на то, что крупный рыбный промысел в крестьянском хозяйстве являлся на Нижнем Амуре, несомненно, доминирующим, по мере удаления от Амурского лимана его значение падало. И одновременно росло значение заготовки рыбы для внутрихо-

\footnotetext{
1 Заработки на крупных рыбных промыслах, расположенных в Амурском лимане, достигали 2500 рублей на семью [21, с. 388$]$.
} 
зяйственного потребления, что объясняется не столько уменьшением объёмов рыбных ресурсов (что также имело место), сколько ростом транспортных затрат, которые увеличивались по мере удаления крестьянских хозяйств от Николаевска крупнейшего рынка сбыта.

Подтверждением могут служить следующие данные 1907 г.: с удалением от устья Амура и приближением к Хабаровску удельный вес промышленников в общем улове уменьшается с 72 до 23\%, а сельского населения - увеличивается с 28 до $77 \%$ [1, с. 108], при этом количество пойманной крестьянами рыбы в Амурском лимане составило 1131850 штук, что более чем в 7 раз превышало крестьянский улов в районе Хабаровска в размере 144850 штук [24, с. 887].

В то же время вовлечённость в рыночные отношения крестьянских хозяйств, располагавшихся на территории вверх по течению Амура, была по-прежнему высока: почти все крестьянские хозяйства были связаны с рынком. Вопрос заключается в данном случае в том, какова была степень зрелости рыночных отношений в конкретной местности.

Так, крестьянские хозяйства, находившиеся на побережье Амурского лимана, попадали в сферу непосредственного влияния Николаевска, который был центром межрайонной рыночной системы ${ }^{1}$. Согласно А.Н. Демьяненко, характерные черты такого рода рыночных систем заключались в следующем. Во-первых, они «распространяли своё влияние на большую часть рыночного пространства социальноэкономического района мезоуровня [Нижне-Амурского района в данном случае Л.Д.]». Во-вторых, они были связаны с другими центрами аналогичных рыночных систем «транспортными магистралями, которые в свою очередь не только обеспе-

\footnotetext{
${ }^{1}$ Подробно типология рыночных систем применительно к особенностям Дальнего Востока начала $\mathrm{XX}$ в. изложена в [6; 7].
}

чивают их связь с рыночными системами других регионов России, но и с внешними рынками» [6, с. 17].

Другая часть крестьянских хозяйств, находившихся на территории между Амурским лиманом и Нижне-Тамбовской волостью, имевших дело с меньшими объёмами рыбных ресурсов и удалённых от Николаевска, а потому не попадавших в сферу влияния Николаевского рынка, обслуживалась внутрирайонными рыночными системами. Такие рыночные системы формировались в переходных зонах между ядром и периферией социальноэкономических районов мезоуровня. Причём центры этих рыночных систем «по своим размерам практически не отличались от большинства других немногочисленных поселений... Выделялись они среди других поселений не столько численностью населения, сколько особенностями их экономико-географического положения» [7, c. 261].

Наконец, в поселениях, наиболее удалённых от Николаевска (НижнеТамбовская и Троицкая волости), где объёмы рыбных ресурсов были не столь значительны, крестьянские хозяйства сбывали свою продукцию на месте. Иначе говоря, обслуживание крестьянских промысловых хозяйств брали на себя мелкотоварные рынки. Как правило, они располагались на периферии социально-экономических районов, были привязаны к достаточно крупным поселениям и обслуживали хозяйства, «которые представляют для обмена крайне незначительные объёмы производимой ими продукции и в то же время располагаются в труднодоступных районах» [7, c. 248].

Особо следует упомянуть, что часть крестьянских хозяйств территории, занимавшей периферийное положение в Нижне-Амурском районе, но прилегавшей к Хабаровску, поставляла свою продукцию на рынки Хабаровской системы. Эта система, так же как и Николаевская, носила межрайонный характер, но по объёму то- 
варооборота рыбной продукции значительно уступала Николаевской.

Снижение товарного значения рыбного промысла в крестьянском хозяйстве сопровождалось нарастанием товарного значения лесных промыслов и охоты. Среди причин такого изменения организационного плана крестьянского хозяйства можно отметить, во-первых, превращение Хабаровска в административный центр Приамурского края, испытывающий потребность в стройматериалах и других видах товарной продукции, во-вторых, развитие пароходства на Амуре, что давало возможность крестьянам сбывать дрова на проходящие пароходы.

\section{Заключение}

Крестьянин-землепашец в ходе колонизации Нижнего Амура не только приспособился к непривычным природным условиям, но и оказался в состоянии оценить и использовать природные ресурсы региона, изменив коренным образом организационный план своего хозяйства, переведя его в рыночный режим, но сохранив при этом связь с землей, необходимую на случай выживания в условиях неблагоприятной рыночной конъюнктуры. При этом соотношения между товарной и нетоварной частями в организационном плане, между промыслами и сельским хозяйством, между различными видами промыслов определялись уровнем зрелости рыночных отношений в конкретной местности. В процессе эволюции трудовое крестьянское хозяйство, приобретая новые черты, продемонстрировало высокую степень адаптационных возможностей и доказало свою способность к выживанию и созиданию.

\section{Список литературы}

1. Алексеев А.И., Морозов Б.Н. Освоение русского Дальнего Востока. Конец XIX в. 1917 г. М.: Наука, 1989. 223 с.

2. Баранский Н.Н. Учет природной среды в экономической географии // В кн.: Баранский Н.Н. Избранные труды. Становление советской экономической географии. М.: Мысль, 1980. С. 72-95.

3. Бражников В.К. Рыбные промыслы Дальнего Востока. СПб., 1900. 290 с.

4. Бродель Ф. Что такое Франция? Пространство и история. М.: Изд-во им. Сабашниковых, 1994. $406 \mathrm{c.}$

5. Гумилев Л.Н. Этногенез и биосфера Земли. 2-е изд. Л.: ЛГУ, 1989. 496 с.

6. Демьяненко А.Н. Локальные рынки юга Дальнего Востока: историко-географический аспект. Автореф. дис. ... д.г.н. СПб., 1996. $33 \mathrm{c}$.

7. Демьяненко А.Н. Территориальная организация хозяйства на Дальнем Востоке России. Владивосток: Дальнаука, 2003. 284 с.

8. Демьяненко А.Н., Дятлова Л.А. Работы представителей отечественной школы экономистов-аграрников конца XIX - начала XX века // В кн.: Демьяненко А.Н. Территориальная организация хозяйства на Дальнем Востоке России. Владивосток: Дальнаука, 2003. С. 47-53.

9. Демьяненко А.Н., Дятлова Л.А. Теоретическое наследие организационно-производственной школы // В кн.: Демьяненко А.Н. Экономическое районирование: вопросы теории и истории. Ч. І. Хабаровск: Хабаровская краевая типография, 2010. С. 148-169.

10. Демьяненко А.Н., Дятлова Л.А., Украинский В.Н. Фернан Бродель и становление геоисторического метода в исследовании экономического пространства // Пространственная экономика. 2013. № 3. С. 161-177.

11. Дятлова Л.А. Историко-географический анализ крестьянского хозяйства Нижнего Амура в конце XIX - начале XX века. Автореф. дис. ... к.г.н. СПб., 1997. 23 с.

12. Дятлова Л.А. Концепция «генетических районов» А.Н. Челинцева // Пространственная экономика. 2005. № 2. С. 144-153.

13. Дятлова Л.А. Пространственные аспекты 
теории крестьянского хозяйства в работах А.В. Чаянова // Пространственная экономика. 2006. № 1. C. 138-148.

14. Исаченко А.Г. Ландшафтоведение и физико-географическое районирование. М.: Высшая школа, 1991. 366 с.

15. Кабузан B.M. Дальневосточный край в XVII - начале XX вв. (1640-1917). М.: Наука, $1985.260 \mathrm{c}$.

16. Ключевский О.В. Русская история. Полный курс лекций в трех книгах. Кн. 1. М.: Мысль, 1995. 572 с.

17. Колобов M.К. К положению рыбопромышленности на Дальнем Востоке // Экономическая жизнь Дальнего Востока. 1923. № 12. C. 33-52.

18. Крестьянские хозяйства Приморской и Сахалинской областей. Владивосток, 1919.

19. Материалы по обследованию крестьянских хозяйств в Приморской области. Т. I. Старожилы стодесятинники. Таблицы. Саратов, $1911.553 \mathrm{c}$.

20. Материалы по обследованию крестьянских хозяйств в Приморской области. Т. II. Старожилы стодесятинники. Таблицы. Саратов, 1911. 521 + XXIV c.

21. Материалы по обследованию крестьянских хозяйств в Приморской области. Т. III. Старожилы стодесятинники. Саратов, 1911.

22. Материалы по обследованию крестьянских хозяйств в Приморской области. T. IV. Старожилы стодесятинники. Описание селений. Саратов, 1912. 575 + XXVI с.

23. Материалы по обследованию крестьянских хозяйств в Приморской области. Т. V. Новоселы, наделенные по душевой норме. Владивосток, 1914. 457 + XLIV с.

24. Приамурье. Факты. Цифры. Наблюдения. M., 1909. 922 c.

25. Пушков П.А. Рыбные промыслы Дальнего Востока. Хабаровск, 1913. 102 с.

26. Сельскохозяйственная перепись 1923 г. на Дальнем Востоке. Вып. 3. Поселенные итоги. Хабаровск, 1925. $230 \mathrm{c}$.

27. Фортунатов А.Ф. Несколько страниц из экономии и статистики сельского хозяйства. М., $1909.84 \mathrm{c.}$

28. Чаянов A.B. Бюджетные исследования. История и методы // В кн.: Чаянов А.В. Из- бранные труды. М.: Финансы и статистика, 1991. C. 25-341.

29. Ярмош A. Задачи и методы промышленной и промысловой колонизации // Экономическая жизнь Дальнего Востока. 1928. № 1. С. 55-66.

\section{References}

1. Alekseev A.I., Morozov B.N. Development of the Russian Far East. The End of the XIX Century - 1917. Moscow, 1989. 223 p. (In Russian)

2. Baranskiy N.N. The Accounting of Environment in Economic Geography. In: Baranskiy N.N. Selected Works. Formation of the Soviet Economic Geography. Moscow, 1980. Pp. 72-95. (In Russian)

3. Brazhnikov V.K. Fisheries of the Far East. S.-Petersburg, 1900. 290 p. (In Russian)

4. Braudel F. The Identity of France. History and Environment. Moscow, 1994. 406 p. (In Russian)

5. Gumilev L.N. Ethnogenesis and Biosphere of Earth. Leningrad, 1989. 496 p. (In Russian)

6. Demyanenko A.N. Local Markets of the South of the Far East: Historical and Geographical Aspect. S.-Petersburg, 1996. 33 c. (In Russian)

7. Demyanenko A.N. Territorial Set-up of the Economy in the Russian Far East. Vladivostok, 2003. 284 p. (In Russian)

8. Demyanenko A.N., Dyatlova L.A. The Works of Representatives of the Native School of Economists-Agrarians in the 19 - early $20^{\text {th }}$ century. In: Demyanenko A.N. Territorial Set-up of the Economy in the Russian Far East. Vladivostok, 2003. Pp. 47-53. (In Russian)

9. Demyanenko A.N., Dyatlova L.A. Theoretical Heritage of Organizational and Production School. In: Demyanenko A.N. Economic Zoning: Questions of Theory and History. Part I. Khabarovsk, 2010. Pp. 148-169. (In Russian)

10. Demyanenko A.N., Dyatlova L.A., Ukrainsky V.N. Fernand Braudel and Formation of Geohistorical Method in the Study of Economic Space. Prostranstvennaya economika [Spatial Economics]. 2013. No. 3. Pp. 161-177. (In Russian)

11. Dyatlova L.A. The Historical and Geographical Analysis of Peasant Economy of Lower Amur River in the late XIX - early XX centuries. 


\section{S.-Petersburg, 1997. 23 c. (In Russian)}

12. Dyatlova L.A. The Concept of «Genetic Regions» by A.N. Chelintsev. Prostranstvennaya economika [Spatial Economics]. 2005. No. 2. Pp. 144-153. (In Russian)

13. Dyatlova L.A. Spatial Aspects of the Farm Theory in A.V. Chayanov's Works. Prostranstvennaya economika [Spatial Economics]. 2006. No. 1. Pp. 138-148. (In Russian)

14. Isachenko A.G. Landscape Science and Physiographic Regionalization. Moscow, 1991. 366 p. (In Russian)

15. Kabuzan V.M. Far East Region in XVII early XX centuries (1640-1917). Moscow, 1985. 260 p. (In Russian)

16. Klyuchevsky O.V. Russian History. Full Course of Lectures in Three Books. $1^{\text {st }}$ Book. Moscow, 1995. 572 p. (In Russian)

17. Kolobov M.K. About a Condition of Fishing Industry in the Far East. Ekonomicheskaya zhiznj Daljnego Vostoka [Economic Life of the Far East]. 1923. No. 1-2. Pp. 33-52. (In Russian)

18. Peasant Farms of Primorskiy and Sakhalinskiy Regions. Vladivostok, 1919. (In Russian)

19. Materials of Survey of Peasant Farms of Primorskiy Region. Vol. I. Saratov, 1911. 553 p. (In Russian)

20. Materials of Survey of Peasant Farms of Primorskiy Region. Vol. II. Saratov, 1911. $521+$ XXIV p. (In Russian)

21. Materials of Survey of Peasant Farms of Primorskiy Region. Vol. III. Saratov, 1911. (In Russian)

22. Materials of Survey of Peasant Farms in Primorskiy Region. Vol. IV. Saratov, 1912. $575+$ XXVI p. (In Russian)

23. Materials of Survey of Peasant Farms of Primorskiy Region. Vol. V. Vladivostok, 1914. $457+$ XLIV p. (In Russian)

24. Priamurye. Facts. Numbers. Observations. Moscow, 1909. 922 c. (In Russian)

25. Pushkov P.A. Fisheries of the Far East. Khabarovsk, 1913. 102 p. (In Russian)

26. Agricultural Census of 1923 in the Far East. Vol. 3. Khabarovsk, 1925. 230 p. (In Russian)

27. Fortunatov A.F. Some Pages from Economy and Statistics of Agriculture. Moscow, 1909. 84 p. (In Russian)

28. Chayanov A.V. Budgetary Researches. His- tory and Methods. In: Chayanov A.V. Selected Works. Moscow, 1991. Pp. 25-341. (In Russian)

29. Yarmosh A. Tasks and Methods of Industrial and Trade Colonization. Ekonomicheskaya zhiznj Daljnego Vostoka [Economic Life of the Far East]. 1928. No. 1. Pp. 55-66. (In Russian)

\section{Для ичитирования:}

Дятлова Л.А. Эволюция крестьянского хозяйства на Нижнем Амуре: влияние природных и социально-экономических условий // Регионалистика. 2014. Т. 1. № 2. C. $17-27$.

For citing:

Dyatlova L.A. Evolution of Lower Amur River Peasant Economy: Influence of Natural and Social-Economic Conditions. Regionalistica [Regionalistics]. 2014. Vol. 1. No. 2. Pp. 17-27. (In Russian) 


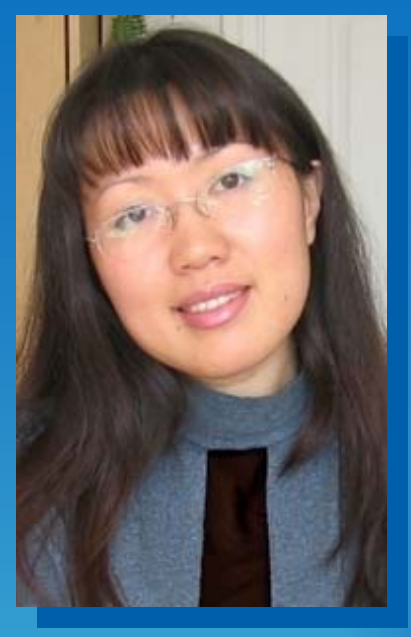

\section{ли}

\section{Елена}

Львовна

Кандидат экономических наук, научный сотрудник Институт экономических исследований ДВО РАН, ул. Тихоокеанская, 153, Хабаровск, Россия, 680042

LI

\section{Elena \\ L'vovna}

Ph.D. in economics, research fellow

Economic Research Institute FEB RAS, 153, Tikhookeanskaya Street, Khabarovsk, Russia, 680042

lee@arr.khv.ru

(С) Ли Е.Л.

Логинова А.Г., 2014

\section{УДК 316.4}

\section{ЮЖНЫЕ РАЙОНЫ ХАБАРОВСКОГО КРАЯ: ОЦЕНКА СОЦИАЛЬНОГО САМОЧУВСТВИЯ НАСЕЛЕНИЯ}

В статье представлены результаты оценки «социальной укоренённости» и «социальной сплочённости», характеризующие параметры социального самочувствия населения сельских территорий. Оценка осуществлялась на основе данных сплошного обследования сельских поселений южной зоны Хабаровского края, проведённого в 2013 г. Показано, что у населения сельских территорий отмечался высокий уровень социальной сплочённости и преобладал естественный, а не вынужденный вид социальной укоренённости.

Сельская местность, социальное самочувствие, социальная укоренённость, сочиальная сплочённость

\section{THE SOUTHERN AREAS OF KHABAROVSK KRAI: EVALUATION OF SOCIAL WELL-BEING OF THE POPULATION}

The article presents the results of the evaluation of «social embeddedness» and «social cohesion» as the definitions of social wellbeing of the population in rural areas. The estimations are based on the materials of mass survey of rural settlements in the southern zone of the Khabarovsk krai in 2013. It is shown that the population of rural territories had high level of social cohesion and the natural, but not the forced social embeddedness.

Rural areas, social well-being, social embeddedness, social cohesion

В основу статьи положены результаты исследования, выполненного при поддержке Правительства Хабаровского края (государственное задание на 2013 г. по теме «Развитие потенциала сельских территорий Хабаровского края»). 


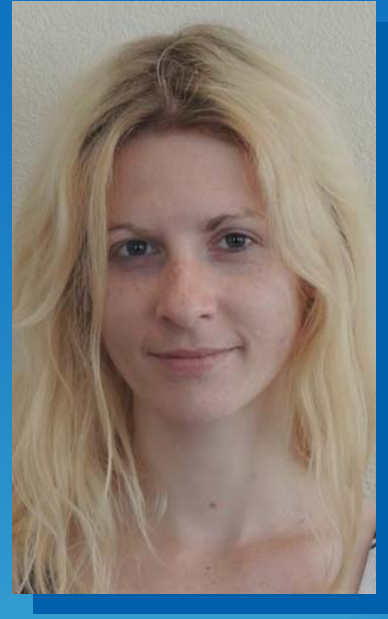

ЛОГИНОВА

Анастасия

Германовна

Эксперт

КГБУ «Агентство

регионального развития»,

ул. Ленина, 15,

Хабаровск, Россия, 680000

\section{LOGINOVA}

\section{Anastasiya}

Germanovna

Expert

Regional State Budget

Organization «Agency of

Regional Development»

15, Lenin Street,

Khabarovsk, Russia, 680000

nas.loginova@gmail.com
DE

\section{Введение}

Южные районы Хабаровского края - это три муниципальных района (район им. Лазо, Вяземский и Бикинский районы), территории которых вписаны в пределы Южной макроэкономической зоны Дальневосточного макрорегиона (puc. 1). Для этой зоны характерны достаточно высокий уровень освоенности территории, как в инфраструктурном отношении, так и с точки зрения систем расселения населения ${ }^{1}$.

Однако динамика социальных процессов указывает на наличие негативных тенденций: снижение экономической активности и вымывание людского потенциала за пределы непосредственно сельских территорий южной группы районов, а также Хабаровского края и Дальнего Востока в целом.

В этой связи возникает необходимость изучения социально-психологических факторов, влияющих на формирование миграционных настроений в обществе и, соответственно, закрепление населения в крае и удовлетворенность этого населения условиями проживания.

В первую очередь авторов работы интересовали два взаимосвязанных между собой исследовательских сюжета: социальная укоренённость и социальная сплочённость жителей сельских населённых пунктов указанных трёх районов Хабаровского края.

Переходя к описанию исследовательского инструментария, необходимо зафиксировать два момента. Во-первых, концептуальным ориентиром на этапе разработки программы исследования стали прикладные полевые статистикоэкономические обследования жизнедеятельности населения, проводившиеся на Дальнем Востоке в начале XX века: Амурская экспедиция ${ }^{2}$ и обследования хозяйств старожилов и новосёлов в Приамурском крае. Во-вторых, перед исследователями стояла двоякая задача: описать сложно формализуемые процессы и количественно охарактеризовать территориальные различия жизнедеятельности населения по отдельным поселениям и муниципальным районам. В этой связи использовался комбинированный подход, объеди-

\footnotetext{
${ }^{1}$ Критерии выделения макроэкономических зон, как единиц первого уровня членения национального экономического пространства, приведены в [2; 3]. В этих же работах дано и достаточно подробное описание как характера экономической деятельности, так и природного и социального контекста, в рамках которого эта деятельность осуществляется.

2 О целях и задачах Амурской экспедиции в части проведения массовых статистико-экономических исследований см. [4].
} 


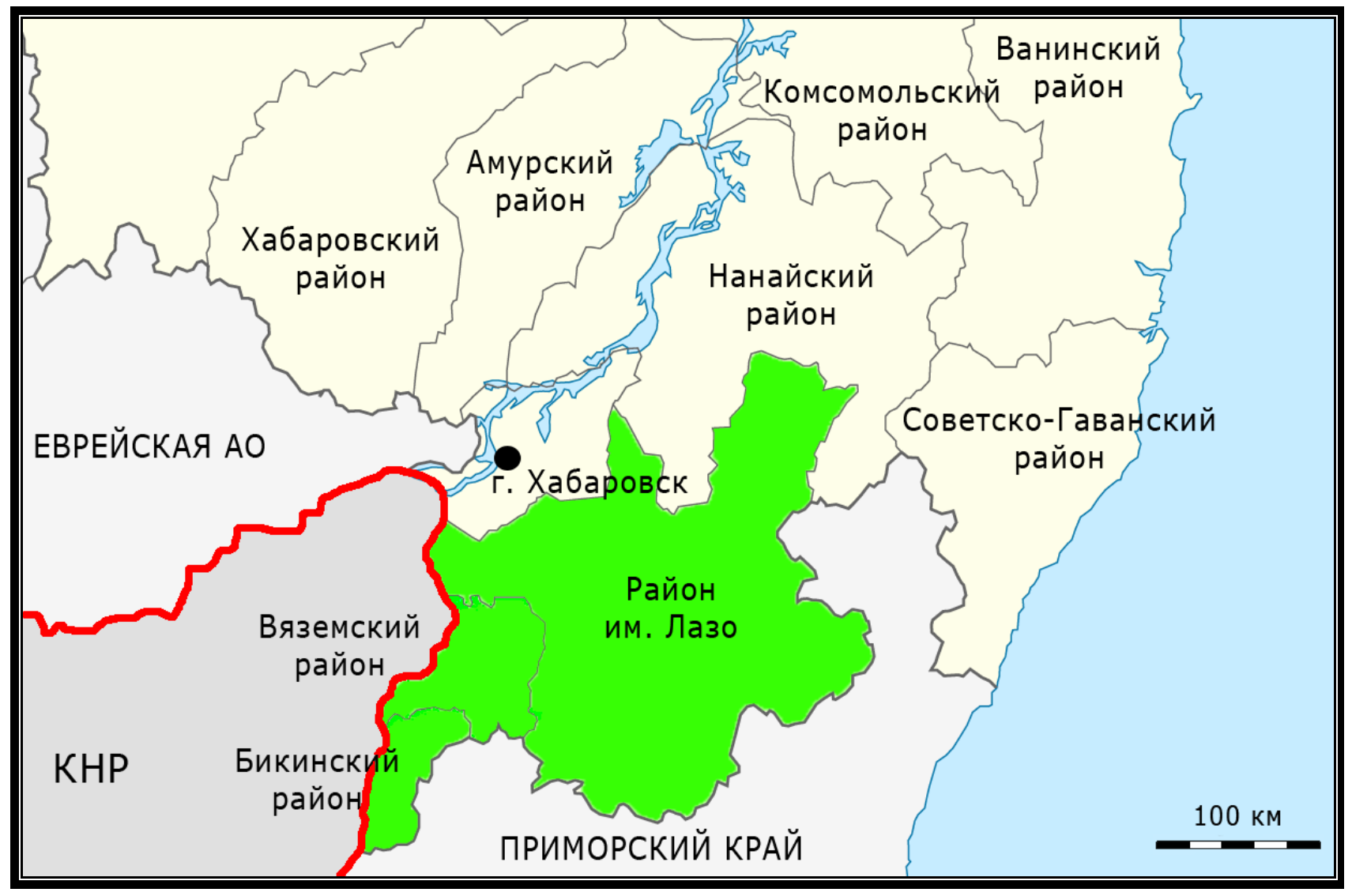

Puc. 1. Южные районы Хабаровского края (зелёная область)

няющий методологию количественных и качественных исследований.

В качестве метода сбора данных послужило индивидуальное очное анкетирование жителей сельских поселений. Применение данного метода позволило исключить влияние представителей органов местного самоуправления на ответы респондентов и, соответственно, на итоговые оценки, а также обеспечило половозрастную репрезентативность и сплошной территориальный охват: общее число охваченных исследованием поселений составило 45 единиц (82 населённых пункта), из них - 44 сельских поселения и 1 поселение городского типа (пгт. Мухен).

Анкетирование проводилось с 25 июня по 19 сентября 2013 г.

Объём районированной выборки, запланированной на этапе разработки программы исследования, составлял 626 рес- пондентов в возрасте от 18 лет и старше (1,5\% генеральной совокупности) и определялся с учётом необходимости обеспечения репрезентативности данных по всем поселениям и по всем анализируемым параметрам. Многоступенчатая квотная (по полу и возрасту) выборка была организована по территориальному признаку (по населённым пунктам сельских поселений). Ошибка выборки составляла 3\%, доверительная вероятность - 95\%.

Процедура формирования выборки включала 2 этапа. На первом этапе осуществлялась группировка поселений по размеру (численности населения) и определялся размер выборки. Сельские поселения муниципальных районов были разделены на 6 групп, для каждой из которых устанавливалось число наблюдений (от 6 до 24 единиц), соответствующее минимальным критериям репрезентативности данных (табл. 1). 
Таблица 1

Распределение поселений по размеру и величине квотной выборки

\begin{tabular}{|l|c|c|c|c|c|c|}
\hline \multirow{2}{*}{\multicolumn{1}{|c|}{ Показатель }} & \multicolumn{5}{|c|}{ Численность населения в поселении, человек } \\
\cline { 2 - 7 } & $\begin{array}{c}\text { Менее } \\
100\end{array}$ & $100-300$ & $300-500$ & $500-1000$ & $1000-3000$ & $\begin{array}{c}\text { Свыше } \\
3000\end{array}$ \\
\hline $\begin{array}{l}\text { Число поселений, } \\
\text { единиц }\end{array}$ & 3 & 7 & 9 & 16 & 7 & 3 \\
\hline $\begin{array}{l}\text { Доля поселений от } \\
\text { общей их численности, } \\
\%\end{array}$ & 6,7 & 15,5 & 20,0 & 35,5 & 15,6 & 6,7 \\
\hline $\begin{array}{l}\text { Число наблюдений, } \\
\text { единиц }\end{array}$ & 6 & 8 & 10 & 16 & 20 & 24 \\
\hline $\begin{array}{l}\text { Доля наблюдений от } \\
\text { генеральной совокуп- } \\
\text { ности, \% }\end{array}$ & 6,0 & 2,7 & 2,0 & 1,6 & 0,7 & 0,6 \\
\hline
\end{tabular}

В связи с отсутствием актуальной статистической информации о половозрастной структуре населения на уровне поселений (последние данные - это результаты Всероссийской переписи населения 2010 г.), определение размера квоты по демографическим группам на втором этапе выполнялось на основе данных избирательной комиссии Хабаровского края (на 1 апреля 2012 г.) о распределении избирателей по территориям.

По способу отбора респондентов выборка являлась гнездовой. Опрос проводился в общественных местах (около магазинов, клубов, отделений «Почты России»), что предполагало равную вероятность попадания всех социальных групп в обследуемую совокупность.

Фактическая численность респондентов составила 614 человек (98\% от запланированного объёма). Отклонение от запланированных размеров выборки на 2\% обусловлено несоответствием фактической численности населения зарегистрированной, отсутствием на момент обследования жителей, обучающихся или работающих в других населённых пунктах, нежеланием отдельных групп населения (мужчин старше трудоспособного возраста) прини- мать участие в опросе. Отклонение фактического объёма выборки являлось незначительным, так как находилось в пределах статистической погрешности.

В обследуемой совокупности соотношение женщин и мужчин составило соответственно $53,3 \%$ и $46,7 \%$, что согласуется с гендерной структурой населения как обследуемых районов, так и Хабаровского края в целом. Возрастные группы также были представлены пропорционально их распределению в районах и крае (табл. 2).

Корреляционный анализ не выявил взаимосвязи интегральных оценок социального самочувствия, уровня активности и удовлетворённости населения с такими демографическими характеристиками респондентов, как возраст и пол: коэффициент корреляции по независимым переменным $(0,3-0,5)$ говорит о несущественном характере связей. Это связано с тем, что в сельских сообществах налажен хороший обмен информацией, способствующий «выравниванию» оценок. Происходящие события и явления обсуждаются в сообществе, что приводит к формированию общего настроя. Это подтверждается такими часто фигурировавшими в ответах формулировками, как «в селе все знают», «все 
Таблица 2

Распределение респондентов по полу и возрасту

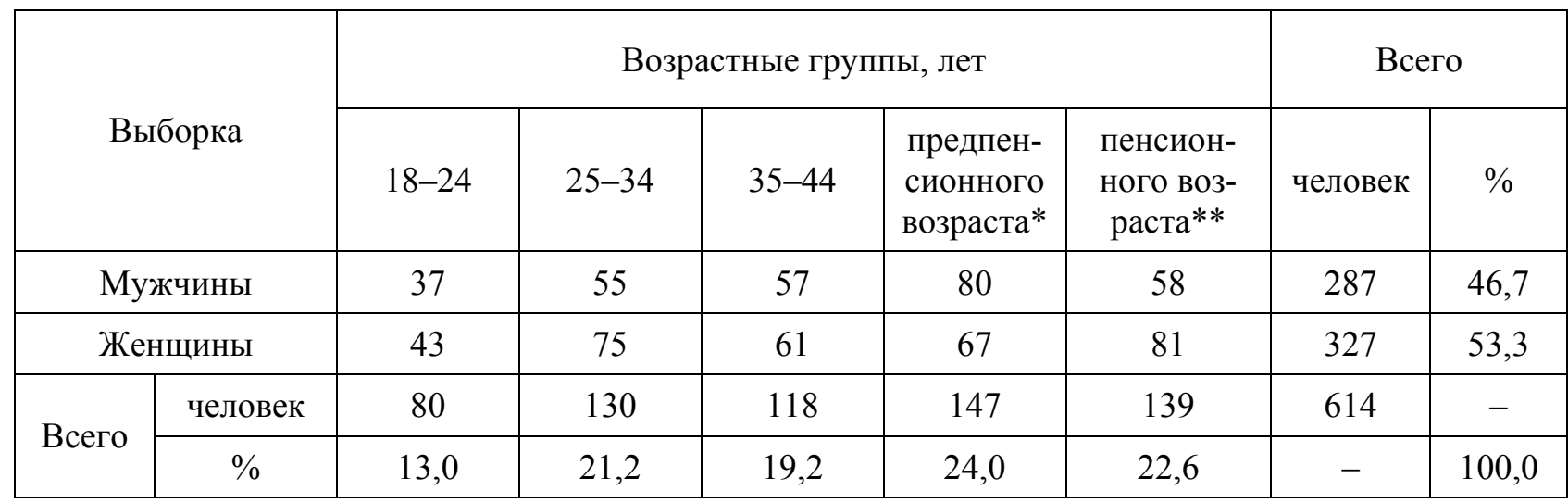

Примечания: * женщины - 45-54 года; мужчины - 45-59 лет;

** женщины - старше 55 лет; мужчины - старше 60 лет.

скажут» и т.д. В этой связи результаты интерпретировались в целом для всего населения, без выделения половозрастных особенностей.

Среди респондентов преобладали люди со средним профессиональным образованием (49,8\%). Доля респондентов с высшим образованием составила 9,4\%. Начальное и общее образование имели $39,9 \%$ опрошенных. Доля пропусков в ответах на вопрос об образовании составила $0,9 \%$. По роду деятельности $51,6 \%$ респондентов принадлежало к категории работающего населения, 41,8 \% - неработающего (в том числе пенсионеров - 24,4\%, безработных - 13,2\%, учащихся - 4,2\%). Ведением домашнего хозяйства занималось 9,6\% респондентов, предпринимательской деятельностью $-1,8 \%^{1}$. Такая структура респондентов по образованию и роду деятельности позволила охватить различные по социально-экономическому статусу группы населения.

Из общего числа работающих в пределах поселения было занято 71,6\%, трудоустроено официально (имеют трудовую

\footnotetext{
${ }^{1}$ Сумма долей всех групп респондентов, указавших род своей деятельности, превысила $100 \%$, поскольку часть пенсионеров отнесла себя также и к категории работающих.
}

книжку и получают «белую» заработную плату) - 86,7\%. Таким образом, полученные оценки социального самочувствия преимущественно характеризуют население, занятое в поселении и имеющее официальный источник дохода.

\section{Социальное самочувствие и его измерение}

По мнению некоторых исследователей [1], разделяемому авторами данной статьи, социальное самочувствие, в том числе и сельских жителей, является важнейшим индикатором удовлетворённости населения условиями жизни. В современных социологических исследованиях предлагаются различные подходы к определению и оценке социального самочувствия, измеряемого с помощью отдельно взятых индикаторов.

В частности, оценки социального самочувствия проводятся Фондом развития гражданского общества. Согласно данным 2013 г., Хабаровский край входил в группу с высоким уровнем социального самочувствия [6]. В данном случае социальное самочувствие оценивалось с позиции социальной активности, выраженной в готовности населения участвовать в политиче- 
ских действиях. Однако данный подход не позволяет корректно оценивать социальное самочувствие в условиях социальнополитической стабильности или пассивности населения.

Другим примером оценки социального самочувствия населения в сельской местности может служить исследование, выполненное в Пермском крае [8]. Здесь социальное самочувствие измерялось посредством субъективной оценки материальной обеспеченности граждан, с выделением следующих 4 слоёв населения: «богатые», «обеспеченные», «со средним достатком» и «бедные». При этом предполагалась прямая взаимосвязь между высоким уровнем обеспеченности и высоким уровнем социального самочувствия и не учитывалась возможность низкого социального самочувствия в группах с высоким уровнем доходов, имеющих высокий уровень неудовлетворённости условиями жизнедеятельности.

Использование единственного показателя для характеристики социального самочувствия сужает содержание и понимание этого феномена. Многообразие условий жизни, оказывающих влияние на общее самочувствие, предопределяет невозможность его измерения с помощью одного индикатора и необходимость использования интегрального подхода. Более того, социальное самочувствие, связанное с конкретными условиями и местом проживания, может рассматриваться на физическом, эмоциональном и ментальном уровнях, отражая комплекс социальнопсихологических, исторических и социально-политических индикаторов.

В этой связи в рамках проведённого исследования под социальным самочувствием понималась интегральная оценка условий и качества жизни населения, определяемая посредством индикаторов физической, эмоциональной и ментальной привязанности к месту проживания:

1. Отношение к месту проживания.
2. Социальная укоренённость.

3. Удовлетворённость деятельностью органов исполнительной власти субъекта РФ и местного самоуправления;

4. Доверие представителям органов власти, местного самоуправления и правопорядка. ния ${ }^{1}$.

5. Социальная сплочённость населе-

Под отношением к месту проживания понималась эмоциональная оценка текущего состояния и образа села в общественном сознании.

Под социальной укоренённостью понималась оценка закреплённости населения, выраженная в длительности проживания респондентов в селе и силе семейных связей.

Под удовлетворённостью понималась субъективная оценка индивидом или группой индивидов степени реализации его (их) потребностей [5; 7; 9, с. 33]. Оценка проводилась по следующим направлениям: здравоохранение; физическая культура и спорт; культура; образование (дошкольное, общее и дополнительное); жилищно-коммунальные услуги; дороги и транспортное обслуживание; безопасность; деятельность органов исполнительной власти и местного самоуправления (района и поселений) и доверие им. Смысловыми аналогами термина «удовлетворён» в анкете выступали термины «устраивает», «нравится» и «доволен»; также в эту группу включались ответы, характеризующие отсутствие замечаний и претензий. Нейтральные ответы («не знаю» и «затрудняюсь ответить»), а также ответыфильтры («нет желания заниматься спортом», «не посещаю») количественно не оценивались.

Под социальной сплочённостью понималась готовность индивида участво-

\footnotetext{
${ }^{1}$ В настоящей работе освещены результаты исследования только по пунктам 1, 2 и 5 представленного набора.
} 
вать в решении наиболее злободневных проблем в селе. Несмотря на то, что «готовность участвовать в решении какихлибо проблем» часто интерпретируется как социальная активность, в данном исследовании использовался именно термин «социальная сплочённость», что объясняется следующими причинами.

Во-первых, активность предполагает действия со стороны индивидов. Однако по степени готовности участвовать в решении проблем села сложно судить о реальной готовности индивидов к действиям. Введение дополнительных фильтров, предполагающих определение формы и размера участия, не позволило бы преодолеть данный недостаток, поскольку респонденты не связывали бы свои ответы с реальными действиями (последствиями). Вероятно, более точные результаты по данному вопросу могли бы получить представители местных сообществ и органов местного самоуправления. В этом случае положительные ответы означали бы не условную готовность участвовать в чёмлибо, а выражение согласия на дальнейшие совместные действия с органами местного самоуправления или представителями общественности. Дальнейшее сопоставление выявленной готовности с реальным участием позволило бы выявить разрыв между намерениями и непосредственными действиями (активностью). Таким образом, измерение активности предполагало бы использование иного инструментария исследования, основанного прежде всего на фиксации действий. Однако в данном случае готовность участвовать в решении наиболее значимых проблем села рассматривалась не с позиции действия, а с позиции эмоционального настроя на их осуществление, то есть социальной сплочённости сельского сообщества.

Во-вторых, социальная активность может иметь как позитивную, так и негативную направленность, а социальная сплочённость может интерпретироваться однозначно: чем выше степень готовности к решению проблем села, тем выше уровень сплочённости, общественного самосознания, взаимопомощи и, соответственно, уровень социального самочувствия. Напротив, низкий уровень социальной сплочённости свидетельствует о разобщённости сельского сообщества и неразвитости механизма оказания взаимной поддержки, что ухудшает параметры социального самочувствия.

\section{Отношение к месту проживания}

Отношение к селу сложно оценить количественно. Использование же качественного подхода позволяет респонденту дать собственные характеристики, не ограниченные жёстким набором предлагаемых вариантов. Поскольку в силу действия общественных догм и стереотипов высока была вероятность получения социально ожидаемых либо устоявшихся в социуме ответов («клише»), не отражающих реального отношения индивидов, это нивелировалось за счёт использования в анкете трёхэтапного фильтра, позволившего получить оценки, «очищенные» от социальных шумов.

На первом этапе респондентам предлагалось ответить на вопрос «Нравится ли Вам здесь жить?». На этот вопрос 78,2\% респондентов дали положительный ответ.

На втором этапе в целях выявления устойчивости, «консистентности» мнений респондентов предлагалось объяснить, чем именно нравится либо не нравится населённый пункт. Все ответы были разбиты (согласно их эмоциональной окрашенности) на три группы: положительные, отрицательные и нейтральные. Анализ обоснований респондентами своего первоначального ответа позволил выявить дополнительную группу - это респонденты, которые указали, что им «нравится населённый пункт, но что-то не устраивает».

В свою очередь, положительные характеристики места проживания были 
сгруппированы в 17 позиций, а отрицательные - в 15 (нейтральные характеристики в дальнейшем не анализировались). Статистически значимыми (более $5 \%$ респондентов) оказались 6 групп характеристик, из них 4 группы - положительных характеристик и 2 - отрицательных (табл. 3).

Привязанность к красивой природе являлась наиболее распространённой положительной характеристикой мест проживания. Это может означать, что связь человека с природой - более значима, чем связь с социумом. Данную характеристику также можно объяснить привязанностью к традиционным видам промыслов (охота, рыбалка, собирательство). При этом важны не столько «кормящие», сколько рекреационные функции ландшафта, а также наличие свободы действий. Проживание в этих условиях противопоставлялось респондентами жизни «в клетках», то есть в многоквартирных домах в городах.

Другая положительная характеристика, связанная с ощущением комфорта и безопасности, раскрывалась через противопоставление жизни в городе и снижение уровня угрозы со стороны других людей (для жителей Бикинского района данная характеристика оказалась более предпочтительной по сравнению с красотой окру- жающей среды).

Хорошая экологическая обстановка также указывает на важность качества среды обитания для людей, проживающих в сельской местности. Данная характеристика имеет сходство с первой из положительных черт места проживания, однако здесь связь с территорией объясняется положительным влиянием местных условий на здоровье (физическое состояние) жителей: респонденты указывали, что в городах «нечем дышать», «продукты - одна химия» и т.П.

Наконец, «малый» патриотизм предполагал выделение респондентами местных корней для объяснения своей удовлетворённости местом проживания. В этой группе ответов часто встречалась мысль, нетипичная для современного мобильного общества: «здесь я буду жить, потому что здесь родился». Данная мысль высказывалась не только пожилыми, но и молодыми людьми, что можно объяснить силой родовых связей или традиций, сложившихся и передающихся из поколения в поколение.

На втором этапе окончательный вывод об отношении к селу не делался, поскольку высказываемые характеристики мест проживания были многочисленными и порою противоречивыми, что не позво-

Таблица 3

Основные варианты ответов, характеризующие положительное и негативное отношение к месту проживания, \%

\begin{tabular}{|l|c|c|c|c|}
\hline \multicolumn{1}{|c|}{ Варианты ответов } & Всего & $\begin{array}{c}\text { Бикинский } \\
\text { район }\end{array}$ & $\begin{array}{c}\text { Вяземский } \\
\text { район }\end{array}$ & $\begin{array}{c}\text { Район им. } \\
\text { Лазо }\end{array}$ \\
\hline \multicolumn{2}{|c|}{ Положительное отношение } \\
\hline 1. Красивая природа & 20,7 & 16,0 & 20,2 & 22,5 \\
\hline 2. Спокойно, тихо, безопасно & 16,8 & 24,0 & 17,2 & 14,1 \\
\hline 3. Хорошая экологическая обстановка & 14,8 & 15,0 & 10,8 & 17,4 \\
\hline 4. Здесь моя родина, моя семья, предки & 14,0 & 14,0 & 8,4 & 17,7 \\
\hline \multicolumn{5}{|c|}{ Отрицательное отношение } \\
\hline 1. Отсутствие перспектив, вымирание & 9,8 & 15,0 & 8,9 & 8,7 \\
\hline 2. Отсутствие предприятий и рабочих мест & 8,6 & 6,0 & 10,3 & 8,4 \\
\hline
\end{tabular}


лило выбрать наиболее значимые из них.

На третьем этапе респондентам предлагалось охарактеризовать населённый пункт одним словом, что заставляло их давать концентрированные определения, которые они считали наиболее подходящими для характеристики села. Такой подход позволил выявить доминанты в суждениях респондентов и более однозначные оценки мест проживания.

Здесь также присутствовал перевес положительных характеристик $(44,1 \%)$ относительно отрицательных (36,8\%), однако разрыв между ними существенно сократился (табл. 4). Более того, в районе им. Лазо обозначилась обратная ситуация: негативные характеристики несколько преобладали над положительными. В целом по всем обследованным сельским территориям 6 групп характеристик были статистически значимыми (5\% и более от числа ответивших). Среди позитивных характеристик села наиболее часто встречались такие, как «хорошее / лучшее», «красивое / привлекательное» и «родное / любимое». Среди отрицательных лидировали «умирающее / разваленное / заброшенное», «плохое / проблемное» и «бесперспективное / нерентабельное».

С экономической точки зрения село рассматривалось респондентами как пред- приятие. Это связано с отождествлением села с колхозом / совхозом. В ответах преобладала позиция, что в текущей ситуации виноваты другие (органы власти, руководители предприятий, не создающие рабочие места) и наблюдалась ориентация «на власть», а не на собственные силы. Респондентами плохо осознавалась возможность самозанятости. По «экономическому» направлению отношение к селу формируется под действием совокупности внешних для респондентов факторов: наличие крупного предприятия и рабочих мест.

Нейтральные характеристики были высказаны 19,1\% респондентов, из которых 16,1\% охарактеризовали село как «нормальное». Сюда попали ответы, в которых нельзя определить эмоциональную нагрузку «нормального» состояния. Здесь преобладали такие ответы, как «село, как село», «как все» и т.п.

Совокупная оценка отношения к селу рассчитывалась исходя из совокупности положительных либо отрицательных характеристик по всем трём вопросам. В целом по сельским территориям отношение к месту проживания являлось положительным (66,9\% респондентов), при этом различия между районами были несущественными (в пределах 5\%). Положительное

Таблица 4

Распределение ответов, характеризующих населённый пункт одним словом, \%

\begin{tabular}{|l|c|c|c|c|}
\hline Как бы Вы описали своё село одним словом? & Всего & $\begin{array}{c}\text { Бикинский } \\
\text { район }\end{array}$ & $\begin{array}{c}\text { Вяземский } \\
\text { район }\end{array}$ & $\begin{array}{c}\text { Район им. } \\
\text { Лазо }\end{array}$ \\
\hline Положстельные характеристики & $\mathbf{4 4 , 1}$ & $\mathbf{5 4 , 0}$ & $\mathbf{4 6 , 8}$ & $\mathbf{3 9 , 2}$ \\
\hline 1. Хорошее / лучшее & 18,1 & 20,0 & 21,7 & 15,1 \\
\hline 2. Красивое / привлекательное & 6,7 & 11,0 & 6,4 & 5,5 \\
\hline 3. Родное / любимое / своё & 6,7 & 4,0 & 3,9 & 2,6 \\
\hline Отрицательные характеристики & $\mathbf{3 6 , 8}$ & $\mathbf{3 4 , 0}$ & $\mathbf{2 9 , 1}$ & $\mathbf{4 2 , 8}$ \\
\hline 1. Умирающее / разваленное / заброшенное & 22,6 & 4,0 & 3,4 & 7,4 \\
\hline 2. Плохое / проблемное & 5,5 & 0,0 & 3,4 & 2,6 \\
\hline 3. Бесперспективное / нерентабельное & 5,0 & 6,0 & 4,6 & 4,8 \\
\hline
\end{tabular}


отношение к месту проживания среди сельских жителей было связано со сферой взаимодействий «человек - природа» и «человек - место», а отрицательное - «человек - экономика». Негативные оценки были обусловлены низким уровнем экономического развития сел, ощущением заброшенности сельских территорий и отсутствием перспектив развития. Важным является то, что положительные оценки формируются в сфере неуправляемых факторов, а отрицательные - в сфере управляемых. При повышении экономической активности среди сельских жителей, вероятно, произойдёт повышение доли лиц, имеющих положительное отношение к сельскому образу жизни и селу.

\section{Социальная укоренённость}

Степень укоренённости сельских жителей оценивалась в два этапа по доле лиц, проживающих в селе с самого рождения либо 10 и более лет, у которых вся семья или большая её часть также проживает в поселении (сила социальных / семейных связей).

На первом этапе учитывалась продолжительность проживания населения с выделением трёх групп: постоянное, условно постоянное и временное население.

Постоянное население, проживающее в селе с рождения, в выборочной совокупности составило 43,2\%. Доля условно постоянного населения (проживающего 10 и более лет) составила 45,4\% (основная часть вселилась в конце 1980-х гг.). Временное население (проживающее менее 10 лет) составило 10,9\%, в том числе вновь вселившиеся (проживающие менее 1 года) $-1,6 \%$.

Данная структура населения сельских территорий юга Хабаровского края сформировалась под воздействием следующих факторов: 1) до 1990-х гг. осуществлялась активная государственная переселенческая и кадровая перераспределительная политика; 2) вследствие сохране- ния миграционных потоков происходило постепенное обновление населенческого состава (в среднем коэффициент обновления населения составляет 1\% в год); 3) в последние годы приток населения в сельские районы фактически прекратился. Поэтому основная часть сельского населения формируется за счёт «старожилов» и их потомков.

На втором этапе оценивалась сила социальных / семейных связей как удельный вес респондентов, чья семья или бо́льшая её часть проживает в одном поселении. При этом предполагалось, что существует прямая взаимосвязь между географической концентрацией / деконцентрацией семьи и потенциальной укоренённостью. То есть чем выше доля респондентов, чьи семьи проживают в том же населённом пункте или поселении, тем выше сила социальных связей или действия «социального якоря». Например, у 85,3\% респондентов, проживающих в своём селе с рождения, в том же населённом пункте или поселении проживает вся или бо́льшая часть их семьи (мабл. 5). Соответственно, у 14,7\% таких респондентов сила социальных / семейных связей в поселении является низкой.

Наибольшая сила социальных / ceмейных связей отмечалась в группах респондентов, проживающих в поселении от 1 года до 5 лет и от 5 до 9 лет $(88,5 \%$ и $91,2 \%$ респондентов соответственно). Вероятно, это связано с тем, что представители данной группы переехали в населённый пункт вместе с семьёй либо прибыли вслед за ней.

Относительно низкой сила социальных связей являлась в группе респондентов, проживающих от 10 и более лет $(71,7 \%)$, что может объясняться оттоком молодого поколения бывших мигрантов в другие населённые пункты - города, имеющие бо́льший объём рынка труда и образовательных учреждений. Данные по группе респондентов, проживающих в селе менее 1 года, являются несопоставимыми, 
Таблица 5

Сила социальных / семейных связей по группам респондентов, выделенным по продолжительности проживания в населённом пункте, \%

\begin{tabular}{|l|c|c|c|c|}
\hline Продолжительность проживания & Всего & $\begin{array}{c}\text { Бикинский } \\
\text { район }\end{array}$ & $\begin{array}{c}\text { Вяземский } \\
\text { район }\end{array}$ & $\begin{array}{c}\text { Район им. } \\
\text { Лазо }\end{array}$ \\
\hline С рождения & 85,3 & 78,3 & 85,9 & 87,2 \\
\hline 10 лет и более & 71,7 & 79,2 & 71,9 & 68,9 \\
\hline От 5 до 9 лет & 91,2 & 100,0 & 100,0 & 82,4 \\
\hline От 1 года до 5 лет & 88,5 & 100,0 & 88,9 & 86,7 \\
\hline Менее года & 80,0 & 0,0 & 85,7 & 66,7 \\
\hline Уровень укоренённости & $\mathbf{6 9 , 8}$ & $\mathbf{7 3 , 6}$ & $\mathbf{6 5 , 3}$ & $\mathbf{7 0 , 6}$ \\
\hline
\end{tabular}

поскольку их доля в общем числе респондентов является низкой.

В целом по южным районам Хабаровского края общий уровень укоренённости населения составил $69,8 \%$, что представляет долю постоянного и условно постоянного населения от общего числа респондентов, у которых в том же населённом пункте находилась вся семья или бо́льшая её часть. Данный уровень укоренённости превышает $50 \%$, то есть бо́льшая часть населения имеет сильную социальную связь с местом проживания. Наибольший уровень укоренённости отмечался в поселениях Бикинского района $(73,6 \%)$, а наименьший - Вяземского района $(65,3 \%)$.

В феномене социальной укоренённости следует выделять два её вида: естественную и вынужденную. Естественная укоренённость наблюдается в тех случаях, когда привязанность обусловлена силой социальных и исторических связей и формирует желание остаться проживать в данном поселении. В этом случае респонденты дают положительные характеристики своему месту проживания. Вынужденная укоренённость имеет место в случаях, когда индивид проживает в данном населённом пункте в силу отсутствия ресурсов и возможностей для переезда в другое место.

В ходе настоящего исследования вынужденная укоренённость была отмечена только 16 респондентами (2,6\% от общего их числа или $3,4 \%$ от числа респондентов, вошедших в группу с высоким уровнем укоренённости). Соответственно, естественная укоренённость преобладала у жителей сельских территорий юга Хабаровского края.

\section{Социальная сплочённость и проблемы развития}

В целом уровень социальной сплочённости населения, выявленный в ходе исследования, может быть оценен как высокий: $84,4 \%$ респондентов выразили своё согласие на участие в решении вопросов местного значения.

Готовность к участию не была сформирована лишь у 15,5\% населения. Среди этих респондентов были выделены (достаточно условно) две категории. В первую $(7,2 \%)$ попали люди, не имеющие физической возможности участия (ввиду преклонного возраста и проблем со здоровьем). Вторую категорию (6,5\%) составили респонденты, не желающие принимать участие в общественной жизни по разным причинам. Одна часть таких респондентов считала, что решение каких-либо вопросов от них не зависит, другая - что задача улучшения жизни в селе полностью лежит на органах власти и управления. В целом позиция отчуждённости объединяла не- 
значительное число респондентов, поэтому можно сказать, что в сёлах были зафиксированы заинтересованность в участии в общественной жизни своего населённого пункта и нацеленность на совместную деятельность по преодолению проблем его развития.

При изучении социальной сплочённости интерес представляет определение сфер, в которых степень её проявления будет максимальной. Это можно сделать на основе ранжирования проблем, которые население считает наиболее злободневными в поселении, а также данных о дефиците товаров и услуг в поселении.

В качестве наиболее острых социально-экономических проблем респонден- ты отметили плохую работу транспорта и неудовлетворительное состояние дорог, низкое качество услуг ЖКХ и недоступность жилья, отсутствие рабочих мест и низкие доходы, а также отсутствие условий для досуга и спорта (табл. б).

Основные выявленные проблемы относились к вопросам местного значения поселенного и районного уровней: ремонт дорог, работа общественного транспорта, содержание жилого фонда, организация досуга и спорта, благоустройство территории, обеспечение связи, организация медицинского обслуживания и общедоступного образования.

Иерархия проблем в районах имела различия. Большая часть проблем (7 из 13)

Таблица 6

Наиболее острые проблемы поселений, \%

\begin{tabular}{|l|c|c|c|c|}
\hline \multicolumn{1}{|c|}{ Проблема } & Всего & $\begin{array}{c}\text { Бикинский } \\
\text { район }\end{array}$ & $\begin{array}{c}\text { Вяземский } \\
\text { район }\end{array}$ & $\begin{array}{c}\text { Район } \\
\text { им. Лазо }\end{array}$ \\
\hline $\begin{array}{l}\text { Плохая работа транспорта и плохое состояние } \\
\text { дорог }\end{array}$ & 41,7 & 40,0 & 37,9 & 44,7 \\
\hline $\begin{array}{l}\text { Низкое качество услуг ЖКХ и недоступность жи- } \\
\text { лья }\end{array}$ & 41,0 & 31,0 & 42,9 & 43,1 \\
\hline Отсутствие рабочих мест и низкие доходы & 38,1 & 42,0 & 38,9 & 36,3 \\
\hline Отсутствие условий для досуга и спорта & 27,9 & 30,0 & 26,1 & 28,3 \\
\hline $\begin{array}{l}\text { Низкое качество и недостаток образовательных } \\
\text { услуг }\end{array}$ & 16,8 & 13,0 & 16,3 & 18,3 \\
\hline Неблагоустроенность села & 16,6 & 15,0 & 11,8 & 20,3 \\
\hline Социальное неблагополучие & 12,1 & 11,0 & 11,8 & 12,5 \\
\hline Низкое качество и недостаток медицинских услуг & 9,9 & 10,0 & 3,0 & 14,5 \\
\hline Отсутствие или перебои связи & 9,3 & 1,0 & 8,4 & 12,5 \\
\hline $\begin{array}{l}\text { Проблемы развития сельского хозяйства и под- } \\
\text { держки личных приусадебных хозяйств }\end{array}$ & 5,7 & 15,0 & 4,4 & 3,5 \\
\hline Плохая работа органов местного самоуправления & 3,9 & 11,0 & 1,0 & 3,5 \\
\hline Отток населения & 3,7 & 5,0 & 4,4 & 2,9 \\
\hline $\begin{array}{l}\text { Проблемы снабжения продуктами и товарами } \\
\text { первой необходимости }\end{array}$ & 3,1 & 6,0 & 2,5 & 2,6 \\
\hline Нет проблем & 2,1 & 3,0 & 3,0 & 1,3 \\
\hline Другое & 7,5 & 9,0 & 7,9 & 6,8 \\
\hline
\end{tabular}


наиболее значима в районе им. Лазо. По остальным 6 проблемам максимум отмечался в Бикинском районе. Вяземский район ни по одной проблеме не имел самых высоких значений, то есть данные проблемы считались бо́льшей частью населения менее значимыми, чем в соседних районах.

В целом высокий уровень социальной сплочённости является следствием тесноты взаимосвязей в сельском сообществе. Активность не носит самостоятельный характер, не приводит к её институционализации в виде некоммерческих образований, а рассматривается как элемент взаимопомощи. При ответах на вопросы этого блока респонденты указывали, что они «готовы помочь, если их попросят». Но это сопровождалось распространённым комментарием, что их «никто не просит» и их мнения «никто не спрашивает». Данные комментарии свидетельствуют о недостаточной включённости населения в местное самоуправление. Поэтому в данном случае социальная сплочённость характеризует потенциальную возможность к объединению местного сообщества при усилении участия населения в обсуждении и решении актуальных вопросов развития села.

\section{Заключение}

Проведённый социологический опрос позволил сделать выводы, касающиеся социального самочувствия сельского населения и удовлетворённости условиями проживания в сельской местности.

1. Степень укоренённости населения сельских территорий юга Хабаровского края можно оценить как высокую. Бо́льшая часть респондентов длительное время проживала в одном населённом пункте, имела разветвлённые социальные связи и была привязана к своей «малой» родине.

2. Социальное самочувствие можно обозначить как достаточно высокое. Ocновными факторами положительного отношения являются привязанность к приро- де и ландшафту села, а также высокая укоренённость.

3. Социальная активность населения характеризовалась готовностью жителей участвовать в решении наиболее важных проблем территории. Доля активного населения в более чем 5 раз превышала долю респондентов, у которых отсутствовало стремление к участию в общественной жизни села.

4. Наиболее острыми являлись проблемы инфраструктурного и социальноэкономического развития села (транспортная доступность, состояние жилфонда, трудоустройство граждан, снабжение медикаментами и продуктами питания и пр.). Бо́льшая часть из выявленных проблем имела статус вопросов местного значения.

Таким образом, несоответствие настроений населения и его поведения (на фоне высокого уровня социальной укоренённости и социальной сплочённости сельских жителей продолжается миграционный отток) можно объяснить тем, что более сильным фактором, определяющим миграционные настроения, является неудовлетворённость населения качеством инфраструктуры, предоставляемых услуг и реализацией полномочий органов местного самоуправления и исполнительной власти края.

\section{Список литературы}

1. Бобкова Е.M., Чугуенко В.M. Новые тенденции в исследовании социального самочувствия населения // Социологические исследования. 2013. № 1. С. 15a-23.

2. Вишневский Д.С., Демьяненко А.Н. Внутрирегиональное разнообразие // Тихоокеанская Россия - 2030: сценарное прогнозирование регионального развития / под ред. П.А. Минакира. Хабаровск: ИЭИ ДВО РАН, 2010. C. $148-168$.

3. Вишневский Д.С., Демьяненко А.Н. Макроэкономическое зонирование как метод регионального стратегического анализа: Дальний Восток России // Пространственная экономика. 2010. № 4. C. 6-31. 
4. Ли Е.Л., Демьяненко А.Н. Амурская экспедиция 1910 года: опыт организации статистико-экономического обследования казачьего и крестьянского хозяйства Амурской области // Пространственная экономика. 2010. № 2 . C. $125-133$.

5. Меримерина М. Опыт типологического анализа при изучении феномена оптимизма / пессимизма // Социология: 4М. 2009. № 29. С. $65-85$.

6. Рейтинг социального самочувствия регионов России. Второй выпуск / Материалы Фонда развития гражданского общества. 2013. (23 декабря). URL: http://civilfund.ru/mat/ view/44 (дата обращения: 18.07.2014)

7. Стандартные определения: систематическое описание диспозиционных кодов и коэффициентов результативности для массовых опросов. (Американская ассоциация исследователей общественного мнения. 3-е изд. 2004 год) // Социологический журнал. 2005. № 2. С. 78-119.

8. Толубаева Л.Т. Социально-экономическое самочувствие сельских жителей Пензенской области: субъективный аспект (по итогам социологических исследований) // Известия высших учебных заведений. Поволжский регион. Общественные науки. 2008. № 4. С. 3-9.

9. Харченко К.В. Удовлетворенность: методология и опыт муниципальных исследований. М: АЛЬПЕРИЯ, 2011. 260 с.

\section{References}

1. Bobkov E.M., Chuguenko V.M. New Trends in the Study of Social Well-Being of the Population. Sotsiologicheskie issledovaniya [Sociological Studies]. 2013. № 1. Pp. 15a-23. (In Russian)

2. Vishnevskiy D.S., Demyanenko A.N. Macroeconomic Zoning as a Method of Strategic Analysis: the Russian Far East. Prostranstvennaya economika [Spatial Economics]. 2010. No. 4. Pp. 6-31. (In Russian)

3. Vishnevskiy D.S., Demyanenko A.N. IntraRegional Diversification. In: The Pacific Russia2030: Scenario Forecasting for Regional Development. Ed. by P.A. Minakir. Khabarovsk, 2010. Pp. 148-168. (In Russian)

4. Lee E.L., Demyanenko A.N. The Amur Expedition in 1910: An Experience of Statistical and Economic Surveys of Cossack and Peasant Farms in the Amur Region. Prostranstvennaya economi$k a$ [Spatial Economics]. 2010. No. 2. Pp. 125133. (In Russian)

5. Merimerina M. The Experience of Typological Analysis in the Study of the Phenomenon of Optimism / Pessimism. Sotsiologiya: $4 M$ [Sociology: 4M]. 2009. № 29. Pp. 65-85. (In Russian)

6. Rating in the Social Well-Being of the Regions in Russia. Issue 2. Materials Civil Society Fund. 2013. (December 23). Available at: http://civilfund.ru/mat/view/44 (accessed 18 July 2014). (In Russian)

7. Standard Definitions: A Systematic Description of Disposition Codes and Outcome Rates for the Polls. $3^{\text {rd }}$ ed. 2004 American Association of Pollsters. Sotsiologicheskiy zhurnal [Journal of Sociology]. 2005. No. 2. Pp. 78-119. (In Russian)

8. Tolubaeva LT Socio-economic Well-Being of Rural Residents of the Penza Region: The Subjective Aspect (Based on Sociological Research). Izvestiya vysshikh uchebnykh zavedeniy. Povolzhskiy region. Obshchestvennye nauki [Proceedings of the Higher Educational Institutions. Volga region. Social Sciences]. 2008. No. 4. Pp. 3-9. (In Russian)

9. Kharchenko K.V. Satisfaction: Methodology and Experience of Municipal Research. Moscow, 2011. 260 p. (In Russian)

\section{Для ичитирования:}

Ли Е.Л., Логинова А.Г. Южные районы Хабаровского края: оценка социального самочувствия населения // Регионалистика. 2014. T. 1. № 2. C. 28-41.

For citing:

Li E.L., Loginova A.G. The Southern Areas of Khabarovsk Krai: Evaluation of Social Well-Being of the Population. Regionalistica [Regionalistics]. 2014. Vol. 1. No. 2. Pp. 2841. (In Russian) 


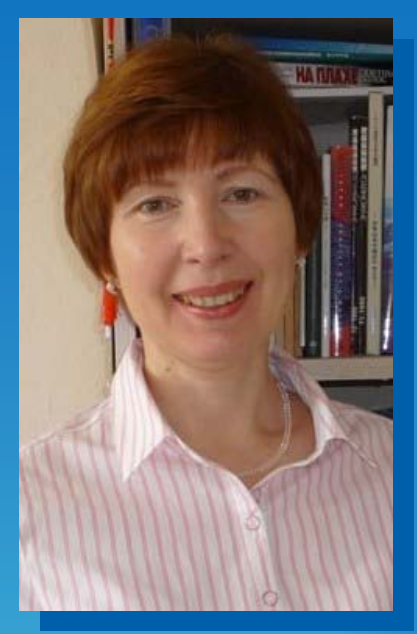

\section{АНТОНОВА}

Наталья

Евгеньевна

Доктор экономических наук, заведующая сектором

Институт экономических исследований ДВО РАН, ул. Тихоокеанская, 153, Хабаровск, Россия, 680042

\section{ANTONOVA}

\section{Natalia}

Evgenyevna

Doctor of economics, section head

Economic Research Institute FEB RAS, 153, Tikhookeanskaya Street, Khabarovsk, Russia, 680042

antonova@ecrin.ru

\section{УДК $330+338$}

\section{ОЦЕНКА РОЛИ РЕСУРСНОГО СЕКТОРА В ЭКОНОМИКЕ РЕГИОНА: ПРИМЕР ХАБАРОВСКОГО КРАЯ}

В статье представлены оценки экономической отдачи ресурсного сектора Хабаровского края (в отраслевом разрезе и в целом по сектору). Исследованы природно-ресурсный потенциал и динамика развития ресурсного сектора. Выделены и проанализированы значимые для экономики инвестиционные проекты сектора. Оценены мультипликативные эффекты ресурсных отраслей на основе матриц социальных счетов.

Ресурсный сектор, матрица социальных счетов, мультипликатор, структурные связи, инвестиционные проекты, Хабаровский край

\section{ESTIMATING THE RESOURCE SECTOR ROLE IN REGIONAL ECONOMY: THE CASE OF KHABAROVSK KRAI}

The article presents the estimation of impact of resource sector as a whole and its industries on the economy of Khabarovsk krai. Natural resources potential, current and prospective status of the resource sector are studied. The authors determine and analyze sector's investment projects that play a significant role for regional dynamics. Based on the Social Accounting Matrix the authors estimate multiplier effects generated by resource sector industries in the regional economy.

Resource sector, social accounting matrix, multiplier, structural linkages, investment projects, Khabarovsk krai

Работа написана на основании материалов, представленных в виде доклада на заседании Экономического совета при Губернаторе Хабаровского края, состоявшемся 16 мая 2014 г. 


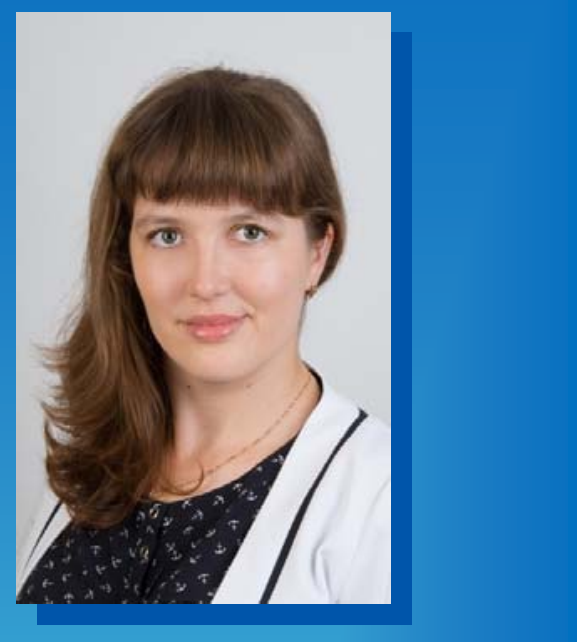

ДЁМИНА

Ольга

Валерьевна

Кандидат экономических наук, научный сотрудник

Институт экономических исследований ДВО РАН, ул. Тихоокеанская, 153, Хабаровск, Россия, 680042

\section{DYOMINA}

\section{Olga}

Valeryevna

Ph.D. in economics, research fellow

Economic Research Institute FEB RAS, 153, Tikhookeanskaya Street, Khabarovsk, Russia, 680042

demina@ecrin.ru

\section{Введение}

Задача адекватного измерения роли ресурсного сектора в экономике региона не нова, но от этого не перестаёт быть актуальной. Вполне понятны традиционные измерители вклад в ВРП, в бюджет, в обеспечение занятости и т.д. Также вполне понятно, что не только эти показатели описывают роль любой отрасли, в том числе и ресурсной, в региональной экономике.

Ресурсный сектор не является доминирующим в структуре достаточно диверсифицированной экономики Хабаровского края. Однако значение таких отраслей, как рыбная, лесная и горнодобывающая, достаточно велико не только для экономики этого региона, но и (по отдельным видам продукции) для национальной экономики.

В настоящей работе предпринята попытка оценить роль ресурсного сектора в экономике Хабаровского края не только на основе традиционных макроэкономических показателей, но и с позиций взаимосвязи ресурсного сектора с другими видами экономической деятельности, его влияния на формирование и изменение структуры экономики региона в целом.

Ресурсный сектор в данной работе представлен следующими видами экономической деятельности (согласно ОКВЭД):

- добыча полезных ископаемых (разделы СА «Добыча топливно-энергетических полезных ископаемых» и СВ «Добыча полезных ископаемых, кроме топливноэнергетических»);

- лесной комплекс (разделы А2 «Лесное хозяйство и предоставление услуг в этой области» и DD «Обработка древесины и производство изделий из дерева»);

- рыбохозяйственный комплекс (разделы В «Рыболовство, рыбоводство» и DA 15.20 «Переработка и консервирование рыбо- и морепродуктов»).

\section{1. Природно-ресурсный потенциал и динамика развития ресурсного сектора Хабаровского края}

\section{Добыча полезных ископаемых}

Минерально-сырьевая база Хабаровского края включает более 400 месторождений, в том числе: 382 - золота, 12 олова, 6 - угля, 4 - платины, 14 - неметаллов, по одному газа, железа и урана. Запасы полезных ископаемых по ключевым их видам представлены в таблице 1. 
Таблица 1

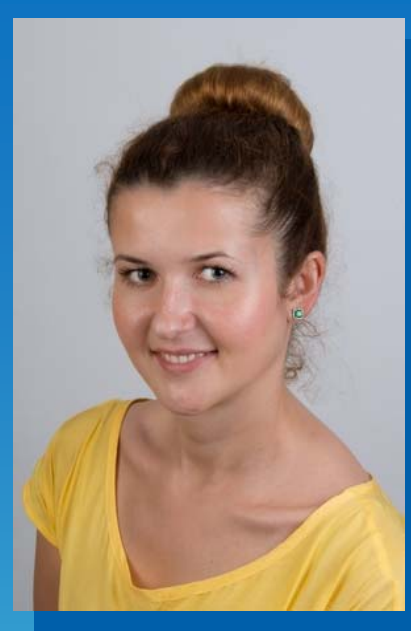

ЗАХАРЧЕНКО

Наталья

Геннадьевна

Кандидат экономических наук, научный сотрудник Институт экономических исследований ДВО РАН, ул. Тихоокеанская, 153, Хабаровск, Россия, 680042

\section{ZAKHARCHENKO} Natalia Gennadyevna

Ph.D. in economics, research fellow

Economic Research Institute FEB RAS, 153, Tikhookeanskaya Street, Khabarovsk, Russia, 680042

zakharchenko@ecrin.ru
Балансовые запасы и обеспеченность запасами ключевых видов полезных ископаемых в Хабаровском крае на 1 января 2013 г.

\begin{tabular}{|l|c|c|}
\hline \multicolumn{1}{|c|}{$\begin{array}{c}\text { Вид полезного } \\
\text { ископаемого }\end{array}$} & $\begin{array}{c}\text { Балансовые } \\
\text { запасы }\end{array}$ & $\begin{array}{c}\text { Обеспеченность } \\
\text { запасами, лет }\end{array}$ \\
\hline Золото рудное, т & $>220$ & $8-10$ \\
\hline Золото россыпное, т & $>40$ & $5-7$ \\
\hline Платина, т & $>30$ & 10 \\
\hline Серебро, т & $>2000$ & более 50 \\
\hline Олово, тыс. т & $>410$ & \\
\hline Медь, тыс. т & $>290$ & более 100 \\
\hline Уголь, млн. т & $>2300$ & \\
\hline
\end{tabular}

Источник: материалы Управления недропользования Министерства природных ресурсов Хабаровского края.

В 2012 г. в Хабаровском крае разрабатывалось 82 месторождения золота, платиноидов, олова, каменного и бурого угля. На 1 июля 2013 г. действовало 247 лицензий на право пользования недрами.

Важной характеристикой для определения перспектив развития горнодобывающего комплекса является не только обеспеченность действующих предприятий сырьём, но и состояние нераспределённого фонда по важнейшим видам полезных ископаемых. «Подушка ресурсной безопасности» по высоколиквидным видам полезных ископаемых в Хабаровском крае практически отсутствует. Так, по состоянию на 1 января 2013 г. в нераспределённом фонде Хабаровского края оставалось лишь 9,6\% от общего объёма запасов золота (в том числе рудного - только $3 \%$ от общего объёма его запасов), платины - 0\%, серебра - $14 \%$. Гораздо лучше ситуация с оловом (37\%), и практически не был «выбран» каменный уголь: доля его запасов, находившихся в нераспределённом фонде, составляла $79 \%$.

Для поддержания достаточного уровня добычи полезных ископаемых в Хабаровском крае необходимо сконцентрировать финансовые ресурсы на приоритетных направлениях геологоразведочных работ (мабл. 2).

При выполнении указанных условий можно ожидать в предстоящий период сохранения современного уровня или даже некоторого роста добычи ключевых видов полезных ископаемых. 

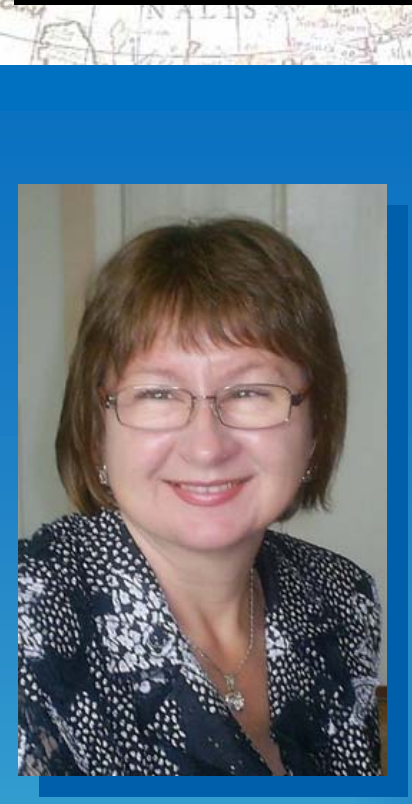

ЛОМАКИНА

Наталья

Валентиновна

Доктор экономических наук, заведующая сектором

Институт экономических исследований ДВО РАН, ул. Тихоокеанская, 153, Хабаровск, Россия, 680042

\section{LOMAKINA}

\section{Natalia}

Valentinovna

Doctor of economics, section head

Economic Research Institute FEB RAS, 153, Tikhookeanskaya Street, Khabarovsk, Russia, 680042

lomakina@ecrin.ru

\section{Таблица 2}

Приоритетные направления геологоразведочных работ в Хабаровском крае и необходимый объём ассигнований на 2011-2030 гг.

\begin{tabular}{|c|c|c|}
\hline $\begin{array}{c}\text { Вид } \\
\text { полезного } \\
\text { ископаемого }\end{array}$ & $\begin{array}{l}\text { Приоритетные направления } \\
\text { геологоразведочных работ }\end{array}$ & $\begin{array}{c}\text { Объём } \\
\text { финансирования, } \\
\text { млн рублей }\end{array}$ \\
\hline \multicolumn{3}{|c|}{$\begin{array}{l}\text { Опережающие прогнозно-минерагенические и } \\
\text { рекогносцировочные поисковые работы }\end{array}$} \\
\hline $\begin{array}{l}\text { Золото } \\
\text { коренное }\end{array}$ & $\begin{array}{l}\text { Матинская, Предджугджур- } \\
\text { ская минерагенические зо- } \\
\text { ны, Этанжинский, Охотский, } \\
\text { Нижнеамурский, Тумнин- } \\
\text { ский, Сихотэ-Алинский и } \\
\text { другие рудные районы }\end{array}$ & 3600 \\
\hline Платиноиды & $\begin{array}{l}\text { Кондерская, Геранская, Лан- } \\
\text { тарская, Баладекская, Катэн- } \\
\text { ская перспективные площа- } \\
\text { ди }\end{array}$ & 400 \\
\hline \multicolumn{3}{|c|}{ Поисковые и поисково-оценочные работы } \\
\hline $\begin{array}{l}\text { Золото } \\
\text { коренное }\end{array}$ & $\begin{array}{l}\text { Албазинское и Кутынское } \\
\text { рудные поля }\end{array}$ & 12200 \\
\hline $\begin{array}{l}\text { Платина } \\
\text { россыпная }\end{array}$ & $\begin{array}{l}\text { Кондерская перспективная } \\
\text { площадь }\end{array}$ & 1000 \\
\hline \multicolumn{3}{|c|}{ Разведочные работы } \\
\hline $\begin{array}{l}\text { Золото } \\
\text { коренное }\end{array}$ & $\begin{array}{l}\text { Албазинское, Кутынское, } \\
\text { Авлаякан, Киранкан, Нони, } \\
\text { Учаминское рудные поля }\end{array}$ & 8000 \\
\hline Всего & & 25200 \\
\hline
\end{tabular}

Источник: материалы Департамента по недропользованию по Дальневосточному федеральному округу.

В общей структуре производства в Хабаровском крае доля горнодобывающего комплекса весьма значительна (puc. 1).

В общей среднесписочной численности занятых в промышленном производстве Хабаровского края доля производственного персонала горнодобывающего комплекса колеблется на уровне 8,9-9,5\%.

В структуре стоимости продукции горнодобывающего комплекса Хабаровского края драгоценные и цветные металлы составляют примерно 95-97\%, общераспространённые полезные ископаемые и минеральные воды - оставшие- 


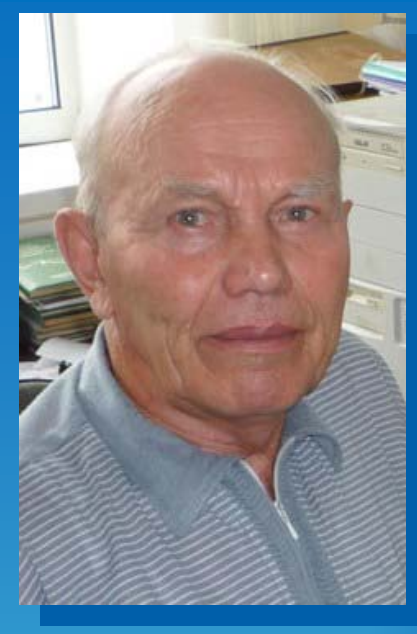

СУХОМИРОВ

Григорий

Исакович

Кандидат сельско-

хозяйственных наук,

старший научный сотрудник

Институт экономических

исследований ДВО РАН,

ул. Тихоокеанская, 153,

Хабаровск, Россия, 680042

\section{SUKHOMIROV}

\section{Grigory}

Isakovich

Ph.D. in agriculture, senior research fellow

Economic Research

Institute FEB RAS,

153, Tikhookeanskaya Street,

Khabarovsk, Russia, 680042

Sukhomirov@ecrin.ru

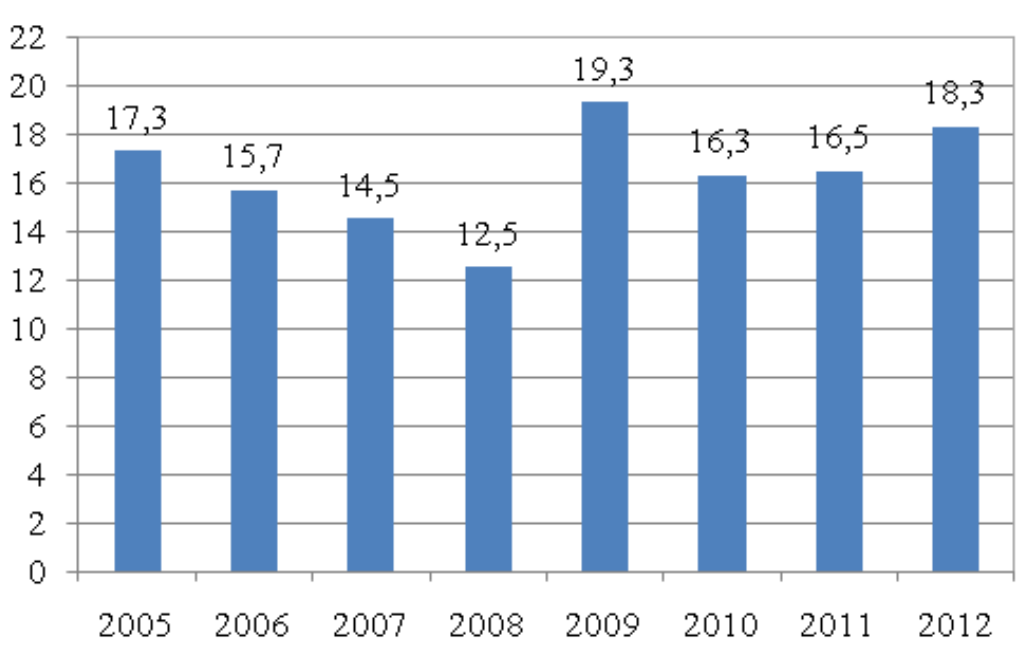

Puc. 1. Доля горнодобывающего комплекса в объёме отгруженных товаров в Хабаровском крае, \%

ся 3-5\%. Динамика выпуска продукции горнодобывающего комплекса Хабаровского края в 2010-2012 гг. представлена в таблице 3.

\section{Таблица 3}

Динамика выпуска продукции горнодобывающего комплекса Хабаровского края, т

\begin{tabular}{|l|r|r|r|}
\hline $\begin{array}{c}\text { Вид полезного } \\
\text { ископаемого }\end{array}$ & \multicolumn{1}{|c|}{2010} & \multicolumn{1}{c|}{2011} & \multicolumn{1}{c|}{2012} \\
\hline Золото & 15,0 & 14,5 & 18,0 \\
\hline в том числе: рудное & 3,9 & 3,7 & 13,9 \\
\hline россыпное & 11,1 & 10,8 & 4,1 \\
\hline Платина & 3,0 & 3,8 & 3,8 \\
\hline Серебро & 92,9 & 90,1 & 142,2 \\
\hline Олово & 149,0 & 182,0 & 280,5 \\
\hline Медь & 69,0 & 0,0 & 134,5 \\
\hline
\end{tabular}

Источник: материалы Управления недропользования Министерства природных ресурсов Хабаровского края.

\section{Лесной комплекс}

Хабаровский край имеет значительные лесные ресурсы: в 2012 г. на его долю приходилось 16,3\% лесопокрытой площади российского Дальнего Востока и 24,8\% запасов 
древесины. По данным государственного учёта, на 1 января 2013 г. общая площадь лесов края составила 75,5 млн га, большая их часть (73,7 млн га) находилась на землях лесного фонда. Лесные земли составляли 59,1 млн га, в том непосредственно лесом было покрыто 50,7 млн га (67\% всего лесного фонда), нелесные земли составляли $22 \%$ общей площади лесного фонда. Запасы древесины оценивались в 5,1 млрд $\mathrm{m}^{3}$, в том числе 3,1 млрд м $^{3}$ спелых и перестойных лесов. Концентрация древесины невелика - $100 \mathrm{~m}^{3} /$ га, а в спелых и перестойных (достигших возраста рубки) насаждениях - $143 \mathrm{~m}^{3} /$ га. Лесистость территории края составляла 66\%, практически не изменившись за 10 лет.

В крае произрастает более 300 видов деревьев и кустарников, основными лесообразующими породами являются лиственница даурская (54,7\% покрытых лесом земель) и ель аянская. В динамике лесных ресурсов за 2003-2013 гг. просматривается тенденция сокращения спелых и перестойных насаждений, снижение доли хвойных и повышение доли лиственных лесов. Наблюдается дефицит эксплуатационных запасов древесины в зонах расположения лесопромышленных предприятий и путей транспорта. Ежегодные темпы выбытия лесов превышают 63,8 тыс. га, из них около 52,9 тыс. га - за счёт сплошных рубок, 10,9 тыс. га - за счёт гибели от пожаров.

В целом по Хабаровскому краю доля эксплуатационных лесов составляет $40,5 \%$ от общей площади лесов, защитных лесов - 14,5\%, резервных - 45,0\%. Сырьевое пользование лесами края традиционно является преобладающим, при этом лидирует древесно-сырьевое пользование: на него приходится основная часть договоров аренды (31\%) и арендуемой площади (99\%). В настоящее время расчётная лесосека в Хабаровском крае составляет около 24 млн м ${ }^{3}$, в том числе доступная - около 16 млн $\mathrm{m}^{3}$. Дальнейшая интенсификация использования лесов требует осуществления мероприятий по повышению их дос- тупности и освоению новых лесных массивов через развитие транспортной инфраструктуры [7].

В 2012 г. в лесном комплексе Хабаровского края работало 422 предприятия ${ }^{1}$, 129 арендаторов имели в аренде 238 лесных участков. В пользование арендаторам было передано 14,6 млн га лесного фонда (27,9\% покрытой лесом площади). Ежегодный разрешённый объём рубки древесины на арендованных участках составил в 2012 г. 11,2 млн м ${ }^{3}$ или 72,7\% доступной расчётной лесосеки.

Фактическая заготовка древесины за 2008-2012 гг. находилась в пределах 6-8 млн м ${ }^{3}$, составляя немного больше половины от разрешенного объема рубки. На долю холдингов (вместе с дочерними предприятиями) приходилось порядка 70\% разрешённого и $50 \%$ фактического объёма заготовки древесины. Малый и средний бизнес, к которому относятся 65\% всех предприятий в лесном комплексе, обеспечивал до $20 \%$ в стоимостном объёме продукции лесозаготовки и переработки.

Хабаровский край занимает прочное лидирующее положение в Дальневосточном федеральном округе в производстве необработанной древесины (в 2012 г. $52,7 \%$ физического выпуска ДФО) и пиломатериалов $(51,8 \%)$, причём доля последних увеличивается (табл. 4). Тем не менее, производство необработанной древесины пока продолжает лидировать в объёмах лесопромышленной продукции Хабаровского края и является основным источником выручки в лесном комплексе края (70\% в 2012 г.).

Деревообработка в крае представлена в основном производством пиломатериалов ( $80 \%$ в объёме выпуска). Несмотря на преобладание самых простых пиломатериалов, развиваются производства с более

\footnotetext{
${ }^{1}$ Состояние и перспективы развития лесной отрасли Хабаровского края (2005-2020 годы). Материалы расширенного заседания Правительства Хабаровского края, состоявшегося 19 июля 2012 г.
} 
Таблица 4

Динамика производства лесопромышленной продукции в Хабаровском крае, тыс. ${ }^{3}$

\begin{tabular}{|l|r|r|r|r|r|}
\hline \multicolumn{1}{|c|}{ Вид продукции } & \multicolumn{1}{c|}{2008} & \multicolumn{1}{c|}{2009} & \multicolumn{1}{c|}{2010} & \multicolumn{1}{c|}{2011} & \multicolumn{1}{c|}{2012} \\
\hline Необработанная древесина & 6448 & 5165 & 5139 & 5462 & 5425 \\
\hline Пиломатериалы & 466 & 514 & 604 & 872 & 993 \\
\hline Плиты МДФ & - & - & - & 6 & 23,5 \\
\hline Шпон & 9,2 & 11,6 & 14,5 & 12,5 & 20,1 \\
\hline Плиты ДСП & 23,7 & 17,3 & 51,3 & 85,3 & 57,8 \\
\hline Технологическая щепа & - & - & 99,8 & 242 & 332 \\
\hline
\end{tabular}

Источники: составлено на основании данных статистического сборника «Лесопромышленный комплекс края в современных экономических условиях» за 2012 и 2013 гг. и доклада о результатах и основных направлениях деятельности Министерства природных ресурсов Хабаровского края за 2012 г.

глубокой переработкой древесины (древесностружечных и древесноволокнистых плит, лущёного шпона), а также производство деревянных строительных конструкций.

Расширение спектра производимой продукции связано с реализацией крупных инвестиционных проектов в лесном комплексе края, направленных на развитие деревообработки. Освоение выпуска этих видов продукции пока незначительное, в частности, незначительный спрос на внешнем рынке на продукцию российских производителей в 2012 г. обусловил нестабильность работы новых производств и повлиял на степень использования производственных мощностей.

Общий объём инвестиций в основной капитал в лесном комплексе края в 20082012 гг. составил 17,1 млрд рублей, из них $78,5 \%$ было направлено в деревопереработку (рис. 2).

В 2012 г. произошёл значительный прирост объёма инвестиций в деревопереработку, что было связано с началом реализации проекта «Дальневосточного центра глубокой переработки древесины» в г. Амурске (ОАО «Дальлеспром», входящего в состав RFP Group). Приход круп- ных игроков в лесной комплекс Хабаровского края привёл к активизации инвестиционного сотрудничества, позволившего привлечь средства крупнейших российских («ВнешэкономБанк», «ВТБ», «ПромСвязьБанк», «Сбербанк») и ряда зарубежных банков.

На лесной комплекс приходится лишь $2,3 \%$ от общей численности занятых в краевой экономике. В структуре занятых по видам деятельности продолжает доминировать лесозаготовка, однако благодаря вводу новых предприятий доля занятых в деревопереработке стала расти - с $12 \%$ в 2008 г. до $22 \%$ в 2012 г. Несмотря на рост заработной платы на предприятиях лесного комплекса, она оставалась ниже, чем средняя оплата труда в экономике края. В лесозаготовке она поднялась в 2012 г. до $95 \%$ от средней по экономике заработной платы, в деревопереработке уровень оплаты труда по сравнению со средней по экономике края снизился с 73\% в 2008 г. до $56 \%$ в 2012 г. Более низкий уровень оплаты труда по сравнению с лесозаготовкой объясняется тем, что на подавляющем большинстве деревообрабатывающих (как правило, небольших) предприятий выпускается продукция невысокого качества, 


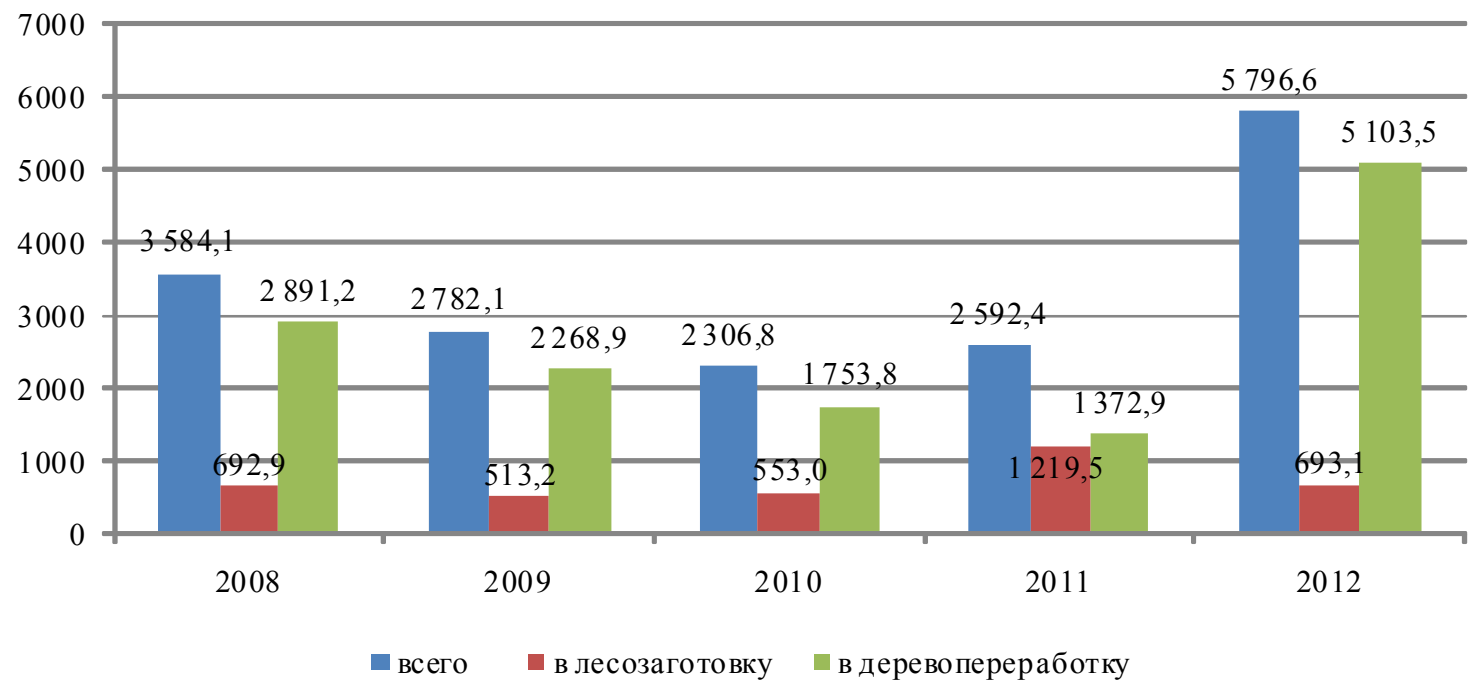

Puc. 2. Динамика инвестиций в лесном комплексе Хабаровского края, млн рублей

Источник: составлено на основании данных статистического сборника «Лесопромышленный комплекс края в современных экономических условиях» за 2009-2013 гг.

используется оборудование низкого технологического уровня и, соответственно, работают низко квалифицированные рабочие с невысокой производительностью труда.

Для многих таёжных населённых пунктов предприятия лесного комплекса являются основой благосостояния населения, так как они единственные обеспечивают возможность занятости местных жителей. В Хабаровском крае лесной комплекс поддерживает жизнедеятельность 159 населённых пунктов с общей численностью населения 132 тыс. человек (10\% населения края $)^{1}$. Предприятия комплекса несут на себе социальную нагрузку в виде поддержки собственных работников, а также территорий, где расположены арендуемые участки. Эта особая социальная роль лесного комплекса также позволяет поддерживать уровень освоенности таёжных районов края [1].

\footnotetext{
${ }^{1}$ Состояние и перспективы развития лесной отрасли Хабаровского края (2005-2020 годы). Материалы расширенного заседания Правительства Хабаровского края, состоявшегося 19 июля 2012 г.
}

В налоговых поступлениях в бюджет края роль лесного комплекса невелика: в 2011 г. его доля составила $2 \%$, в 2012 г. $1,5 \%$ от налоговых доходов краевого бюджета. Лесозаготовка обеспечивает 90\% поступлений налогов, поскольку остаётся основным видом деятельности в комплексе. В структуре налогов, поступающих в бюджет края от лесопромышленных предприятий, основную долю составляет налог на доходы физических лиц (его доля в сумме всех уплаченных налогов в 2012 г. составила $63,2 \%$ ). Стабильными являются поступления от региональных налогов (на имущество организаций и транспортного налога), суммарная доля которых колеблется от 20 до $25 \%$. Низкая доля налога на прибыль объясняется убыточностью предприятий лесного комплекса - доля убыточных предприятий в 2012 г. составила в лесозаготовке $61,8 \%$, в деревопереработке $-77,8 \%$.

Основной объём лесопромышленной продукции поставляется на внешние рынки. В 2010-2012 гг. объёмы экспортируемой необработанной древесины сократи- 
лись на 14\% из-за повышения пошлин на этот вид экспортных товаров и роста спроса на продукцию деревообрабатывающих предприятий края. Несмотря на неблагоприятную рыночную конъюнктуру, лесопромышленная продукция продолжает сохранять лидирующее положение в товарной структуре экспорта Хабаровского края (puc. 3).

\section{Рыбохозяйственный комплекс}

Морские рыбохозяйственные ресурсы Хабаровского края в целом можно оценить как относительно стабильные, в настоящее время более $70 \%$ добычи приходится на морской промысел. Его объектами являются минтай, сельдь, треска, палтус, камбала, крабы, кальмары, креветки и ламинария. Основную долю в общем объ-

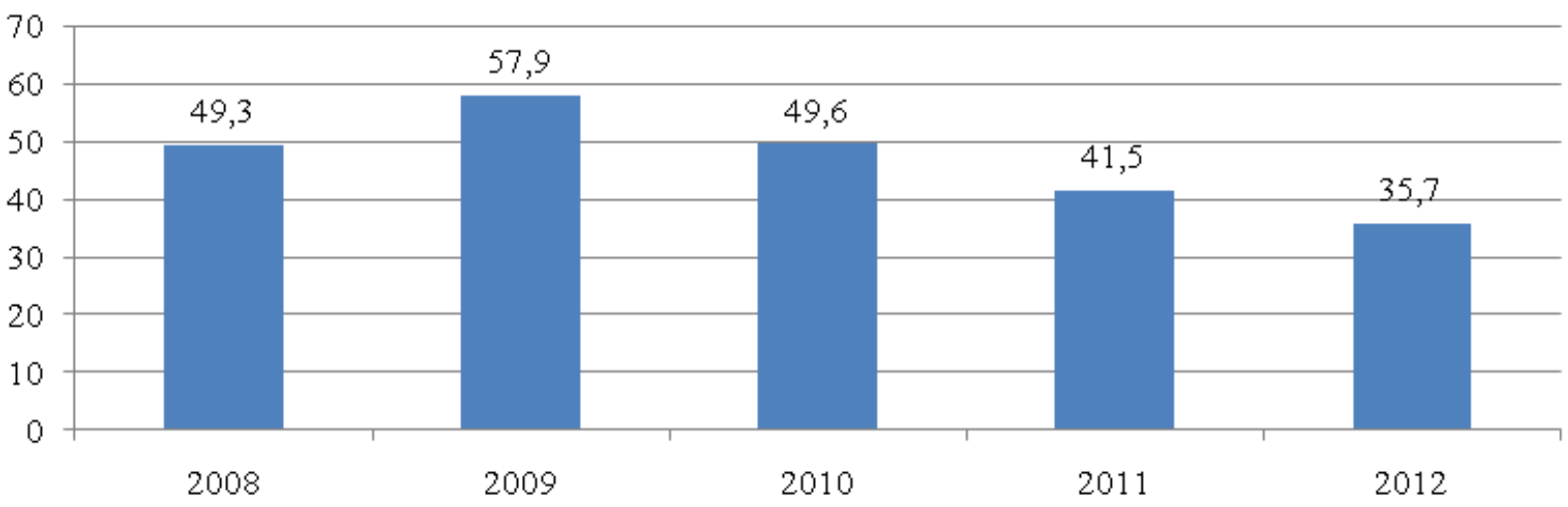

Puc. 3. Доля лесопромышленной продукции в стоимостном объёме экспорта Хабаровского края, \%

Источник: Внешнеэкономическая деятельность Хабаровского края: Статистический сборник / Территориальный орган Федеральной службы государственной статистики по Хабаровскому краю. Хабаровск, 2013. C. 9 .

Лесной комплекс края продолжает ориентироваться на восточноазиатский рынок, где крупнейшим покупателем остаётся Китай. Однако в последние годы его доля в экспорте круглой древесины из края стала снижаться как в стоимостном, так и в физическом объёмах, что связано с изменением предпочтений китайских потребителей необработанной древесины в пользу поставщиков из США, Канады, а также Новой Зеландии. Благоприятным фактором является стабильный интерес Китая к российским пиломатериалам, что позволяет надеяться на сохранение и даже увеличение доли этого вида продукции в поставках, осуществляемых на внешние рынки. ёме добычи составляет минтай (более $1 / 3$ ). До 30\% вылова приходится на прибрежный промысел и внутренние водоёмы (лосось, нерестовая сельдь, мойва, корюшка, крабы, кальмар, ламинария, пресноводные виды рыб). Основные рыбные ресурсы внутренних водоёмов края находятся в бассейне Амура, в котором встречается более 100 видов рыб (25 из которых являются объектом промысла). По данным Хабаровского отделения ТИНРО-Центра, в 1995-2012 гг. запасы промысловых пресноводных видов рыб в Амуре увеличились в 1,6 раза, объёмы допустимых уловов (ОДУ) увеличились почти в 2,4 раза.

Процент освоения промыслового запаса тоже увеличился (до 75\% в 2012 г.). Квоты по вылову минтая, сельди, камчатского краба и лососевым, как правило, вы- 
полняются, по остальным видам - чаще недовыполняются. Соответственно, кроме перечисленных промысловых видов, остальные рыбные ресурсы Хабаровского края недоосваиваются, особенно ресурсы мойвы, трески, камбалы, корюшки, бычков, терпуга, кальмаров, крабов (кроме камчатского), ламинарии, что позволяет значительно увеличить их добычу. При условии восстановления ресурсов путём воспроизводства и регулирования их численности можно увеличить добычу лососевых. Развитие и воспроизводство водных биологических ресурсов на территории Хабаровского края осуществляется на 7 рыбоводных заводах (трёх государственных и четырёх частных). Общая мощность заводов - 89,1 млн штук молоди лососевых в год.

По данным Комитета рыбного хозяйства Министерства природных ресурсов Хабаровского края, в 2012 г. добычей и переработкой рыбы и морепродуктов занималось 135 предприятий и рыболовецких колхозов. Более 95\% предприятий относилось к малому и среднему бизнесу. При этом $2 / 3$ общей добычи приходилось на долю всего лишь девяти предприятий.
В последние несколько лет наблюдалась положительная динамика добычи гидробионтов в крае, её объём в 2012 г. составил 237,7 тыс. т, что являлось лучшим показателем за 15-тилетний период (табл. 5). Это сопровождалось стабильным ростом объёмов промышленной переработки в 2008-2012 гг. (табл. б). В структуре видов продукции продолжала лидировать замороженная рыба, но наряду с этим наблюдалось увеличение количества видов и объёма продукции высокой степени переработки (её доля в общем объёме физического выпуска составила 14,5\%).

Инвестиции в основном шли на модернизацию существующих и создание новых производственных мощностей в рыбодобыче, на приобретение небольших линий по переработке продукции, а также на воспроизводство рыбных ресурсов (главным образом, за счёт собственных и заёмных средств предприятий).

Доля работников рыбохозяйственного комплекса в общей численности занятых в экономике края очень незначительна - лишь 0,6\%. Основная часть работников комплекса занята в рыболовстве $(87,4 \%)$, однако в последние годы стала расти чис-

Таблица 5

Динамика вылова водных биологических ресурсов в Хабаровском крае, тыс. т

\begin{tabular}{|l|c|c|c|c|}
\hline \multicolumn{1}{|c|}{ Объект промысла } & 2009 & 2010 & 2011 & 2012 \\
\hline Минтай & 95,6 & 110,1 & 101,4 & 107,4 \\
\hline Лососевые & 38,1 & 46,7 & 33,9 & 51,6 \\
\hline Сельдь & 31,4 & 32,2 & 48,5 & 47,1 \\
\hline Прочая рыба & 10,7 & 12,0 & 17,6 & 21,9 \\
\hline Крабы & 2,9 & 4,5 & 4,3 & 5,5 \\
\hline Креветки & 1,5 & 1,6 & 1,4 & 1,3 \\
\hline Кальмар & 1,2 & 1,1 & 0,5 & 1,2 \\
\hline Прочие объекты промысла & 0,6 & 0,2 & 1,5 & 1,6 \\
\hline Всего & 182,0 & 208,4 & 209,2 & 237,7 \\
\hline
\end{tabular}

Источник: составлено на основании данных Комитета рыбного хозяйства Министерства природных ресурсов Хабаровского края. 
Таблица 6

Динамика производства рыбной продукции по видам, тыс. т

\begin{tabular}{|l|c|c|c|c|c|}
\hline \multicolumn{1}{|c|}{ Показатель } & 2008 & 2009 & $2010^{*}$ & $2011^{*}$ & $2012^{*}$ \\
\hline $\begin{array}{l}\text { Товарная пищевая рыбная про- } \\
\text { дукция, включая консервы рыб- } \\
\text { ные }\end{array}$ & 155,4 & 167,0 & - & - & - \\
\hline $\begin{array}{l}\text { Рыба и продукты рыбные пере- } \\
\text { работанные и консервированные }\end{array}$ & - & - & 175,7 & 182,1 & 200,0 \\
\hline $\begin{array}{c}\text { в том числе рыба мороженная } \\
\text { (без сельди) }\end{array}$ & 90,8 & 103,5 & 125,2 & 124,1 & 144,2 \\
\hline
\end{tabular}

Примечание: * данные приведены согласно общероссийскому классификатору продукции ОК 034-2007.

Источники: составлено на основании данных статистического сборника «Рыбопромышленный комплекс края» за 2010-2013 гг.

ленность занятых в рыбопереработке. Несмотря на незначительный вклад в занятость в экономике края, рыбохозяйственный комплекс выполняет такую же важную социальную роль обеспечения жизнедеятельности прибрежных посёлков, как и лесной комплекс - для таёжных поселков. В рыбохозяйственном комплексе растёт оплата труда, как в добыче рыбы, так и в её переработке. В 2012 г. средняя зарплата в рыбопереработке достигла 37,9 тыс. рублей и превысила средний уровень оплаты труда в экономике края.

Растет доля налогов от рыбной отрасли, поступающих в краевой бюджет. Если в 2010 г. она составляла 65,4\% от суммы налоговых поступлений из рыбохозяйственного комплекса во все уровни бюджетной системы, то в 2012 г. она достигла $85 \%$.

Хабаровский край, как по добыче, так и по экспорту рыбы и рыбной продукции, прочно занимает четвёртое место в ДФО. При этом рост объёма экспорта рыбы и рыбной продукции из края обеспечивается главным образом за счёт мороженой рыбой, доля которой составила $88,0 \%$. В товарной номенклатуре экспорта мороженой рыбы преобладает минтай $(68,2 \%)$. Основными импортерами являются Китай,
Республика Корея и Япония. В 2012 г. на внутренний рынок было поставлено 86,6 тыс. т рыбной продукции, более половины ёё - реализовано на территории края. Увеличиваются объёмы и ассортимент поставляемой в торговые предприятия края продукции высокой степени переработки: в 2012 г. такой продукции поставлено более 12 тыс. т (порядка 75\% потребности внутрикраевого товарного рынка).

Некоторые показатели, характеризующие прямой вклад ресурсного сектора в краевую экономику, представлены в таблице 7. На взгляд авторов, этот вклад достаточно весом. Особенно, если соотнести доли в отгруженной продукции, в экспорте и т.д. с долей занятых в ресурсном секторе края.

\section{2. Ресурсный сектор в экономике Хабаровского края: оценка мультипликативных эфрфектов}

Анализ динамики развития ресурсного сектора и его вклада в региональные макроэкономические показатели является достаточно традиционным, но далеко не всеобъемлющим. Такие концепции, как «ресурсное проклятие», «голландская бо- 
Таблица 7

Прямой вклад ресурсного сектора в экономику Хабаровского края в 2012 г., \%

\begin{tabular}{|l|c|c|c|c|c|}
\hline \multicolumn{1}{|c|}{ Показатель } & $\begin{array}{c}\text { Добыча } \\
\text { угля }\end{array}$ & $\begin{array}{c}\text { Горнодо- } \\
\text { бывающий } \\
\text { комплекс }\end{array}$ & $\begin{array}{c}\text { Лесной } \\
\text { комплекс }\end{array}$ & $\begin{array}{c}\text { Рыбохозяй- } \\
\text { ственный } \\
\text { комплекс }\end{array}$ & $\begin{array}{c}\text { Ресурсный } \\
\text { сектор в } \\
\text { целом }\end{array}$ \\
\hline $\begin{array}{l}\text { Доля в налоговых поступ- } \\
\text { лениях в бюджет края }\end{array}$ & 0,8 & 9,1 & 1,5 & 1,0 & 12,4 \\
\hline $\begin{array}{l}\text { Доля в отгруженной про- } \\
\text { дукции }\end{array}$ & 3,7 & 16,4 & 8,4 & 4,0 & 32,5 \\
\hline $\begin{array}{l}\text { Доля в численности заня- } \\
\text { тых }\end{array}$ & 0,3 & 1,4 & 2,3 & 0,6 & 4,6 \\
\hline Доля в инвестициях & 3,0 & 3,6 & 3,4 & 0,2 & 10,2 \\
\hline Доля в экспорте & 7,7 & $\ldots$ & 28,7 & 8,1 & $44,5 *$ \\
\hline
\end{tabular}

Примечание: * оценка приведена без учёта горнодобывающего комплекса.

Источник: составлено авторами.

лезнь», «сырьевая игла» и т.п., отражают желание и попытки увязать эффективность освоения природных ресурсов с различными аспектами экономического развития. Задача системной оценки роли ресурсного сектора в этом развитии является актуальной и в научном, и в практическом плане (в смысле формирования эффективной экономической политики).

В настоящей работе, пытаясь решить такую задачу, авторы поставили перед собой следующий набор целей - уловить импульсы, исходящие от отраслей ресурсного сектора к другим видам экономической деятельности Хабаровского края, количественно измерить «мощность» таких импульсов, выявить пути их прохождения и в целом определить степень интегрированности ресурсного сектора в региональную экономику, его стимулирующее (или дестимулирующее) воздействие.

Для получения системной оценки эффектов, генерируемых в экономике Хабаровского края ресурсным сектором, был использован метод матриц социальных счетов [2-4]. Матрица социальных счетов (MCC) представляет собой расширенную балансовую модель, отражающую структурные параметры экономических потоков всех стадий регионального воспроизводственного цикла. Взяв за отправную точку 2010 г., авторы получили оценки детализированной МСC Хабаровского края, включающей четыре блока счетов:

1) счета производства 34 видов экономической деятельности, в том числе 5 видов деятельности, относящихся к ресурсному сектору (лесное хозяйство; рыболовство, рыбоводство ; добыча топливно-энергетических ресурсов (ТЭР); добыча полезных ископаемых, кроме ТЭР; обработка древесины и производство изделий из дерева);

\footnotetext{
${ }^{1}$ В силу невысокой доли переработки рыбо- и морепродуктов в общем объёме выпуска рыбохозяйственного комплекса Хабаровского края $(1,3 \%)$, в региональной матрице социальных счетов «рыболовство, рыбоводство» объединяет два вида деятельности - собственно «рыболовство, рыбоводство» и «переработка, консервирование рыбо- и морепродуктов».
} 
2) счета факторов производства (труд и капитал);

3) текущие счета институциональных секторов (домашние хозяйства, реальный сектор, федеральное правительство, региональное правительство, остальная страна и остальной мир);

4) капитальные счета институциональных секторов, а также финансовый счёт кредитных организаций.

В МСС работа ресурсного сектора рассматривается не только с позиций межотраслевых взаимодействий, но и с учётом участия в экономическом обороте различных институциональных секторов. Схема, отражающая этапы информационного наполнения МСС региона, представлена на рисунке 4.
Количественные оценки роли ресурсных отраслей в экономике региона строятся на основе модели матричных мультипликаторов, представленной на рuсунке 5 в сетевой постановке.

Сети описывают трансформацию импульсов ресурсного сектора в прирост выпуска и доходов в регионе как процесс последовательного «наслоения» прямых и косвенных эффектов, обусловленных межотраслевыми взаимодействиями и ростом конечного спроса.

Таким образом, модель матричных мультипликаторов позволяет, во-первых, получить комплексную оценку реакции валового выпуска и доходов в регионе на изменение объёмов выпуска ресурсного

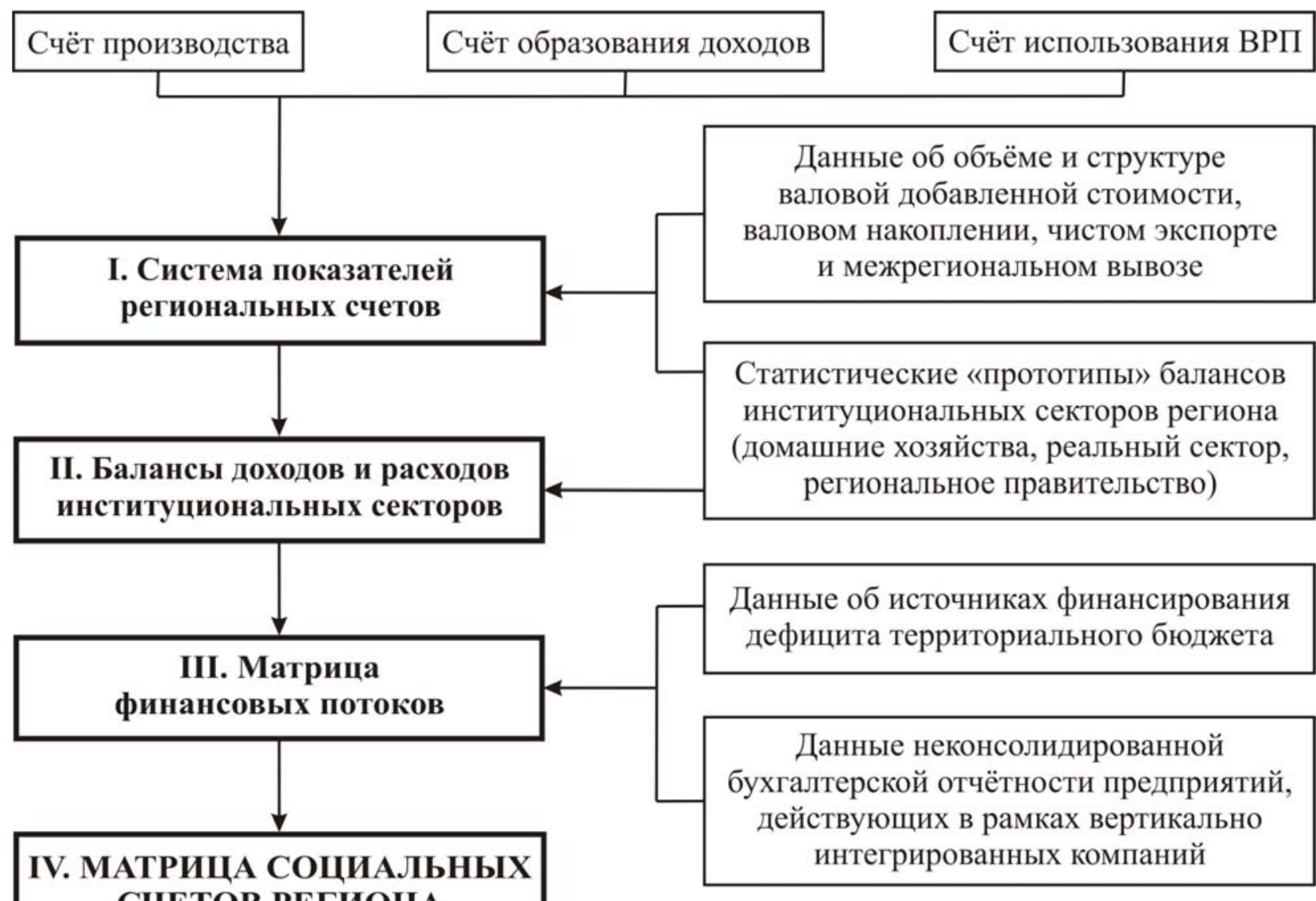

Puc. 4. Этапы оценки матрицы социальных счетов региона

Источник: составлено авторами. 


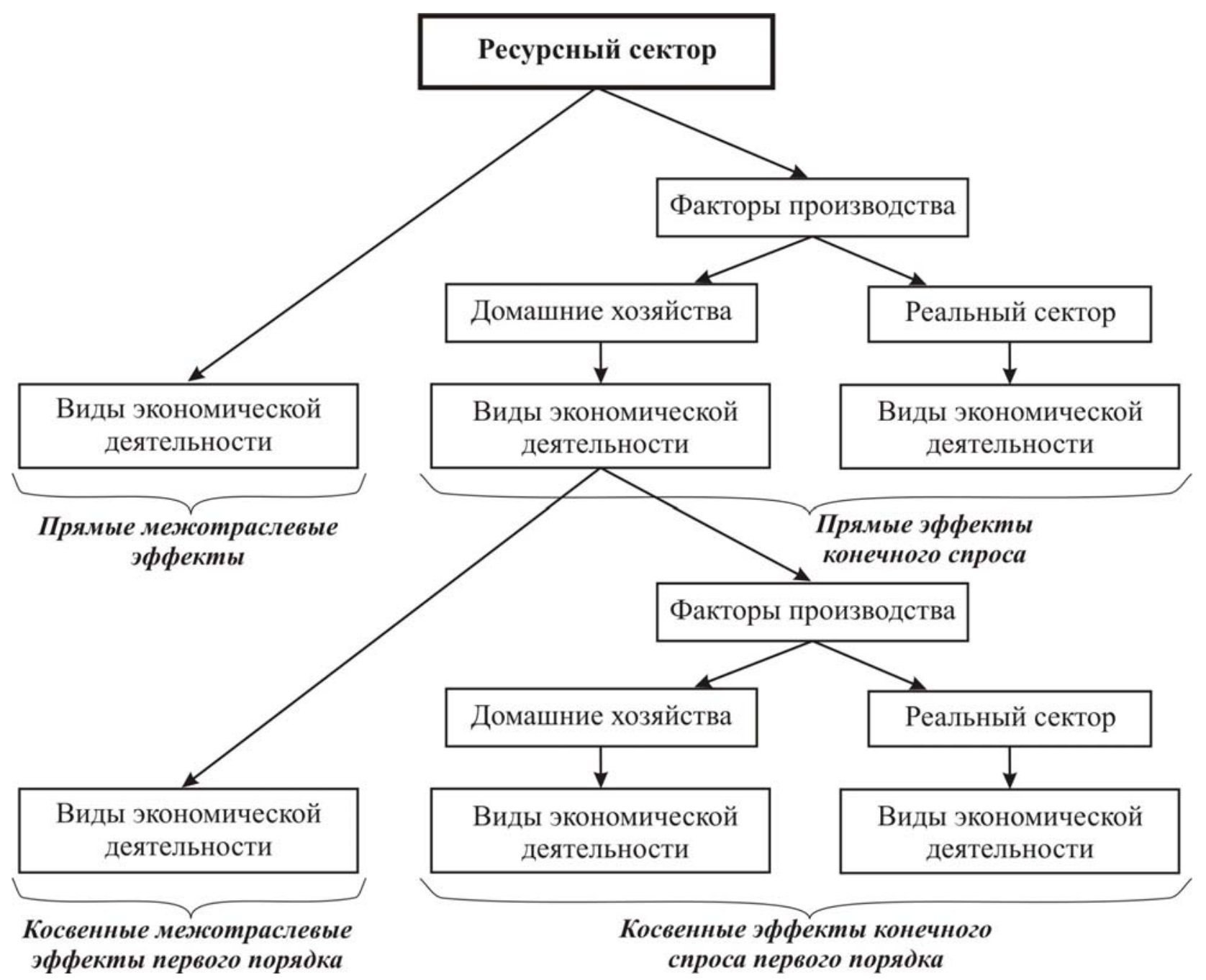

Puc. 5. Сетевая модель распространения импульсов ресурсного сектора в экономике региона

Источник: составлено авторами.

сектора, во-вторых, выявить наиболее перспективные с точки зрения величины генерируемых эффектов цепочки взаимосвязей ресурсного сектора с другими элементами региональной системы.

Полученные на базе МСС оценки эффектов, генерируемых в экономике Хабаровского края ресурсным сектором, представлены на рисунке 6. Например, рост выпуска обработки древесины на 1000 рублей продуцирует увеличение валового выпуска в регионе на 1802,6 рубля, доходов - на 1 247,8 рубля.

Определяющую роль в ранжирова- нии ресурсных отраслей по величине мультипликативного эффекта играет степень сложности и замкнутости на региональном уровне их структурных взаимосвязей. На основе декомпозиции представленных мультипликаторов проведена оценка структурных взаимосвязей каждой ресурсной отрасли с другими элементами региональной экономической системы. По результатам оценок, выделены, во-первых, виды деятельности, выпуск которых наиболее чувствителен к росту выпуска ресурсных отраслей и, во-вторых, наиболее репрезентативные пути, транслирующие 


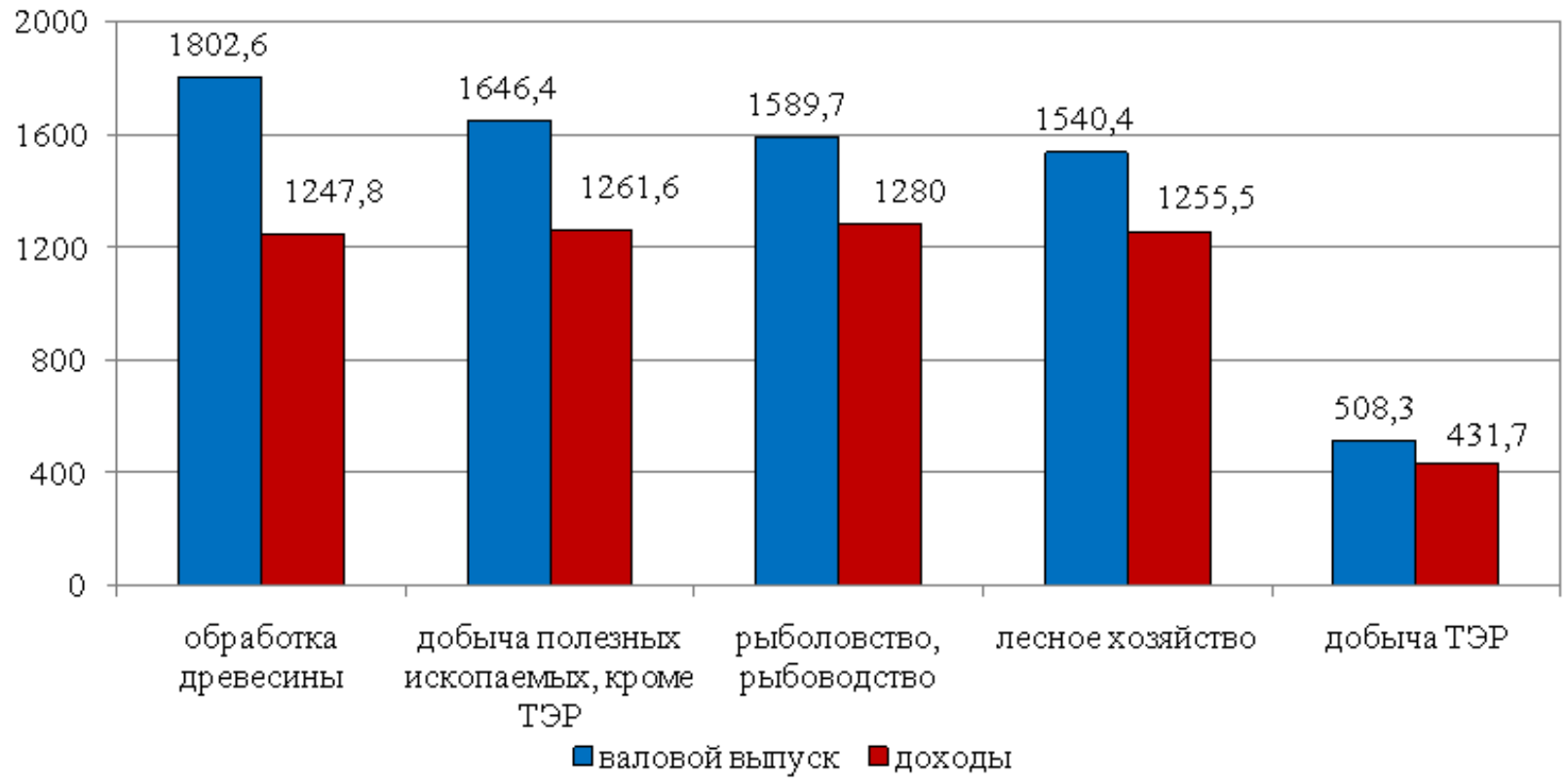

Puc. 6. Влияние ресурсного сектора на валовой выпуск и доходы в регионе (мультипликаторы МСС), рублей / тыс. рублей.

Источник: рассчитано авторами.

импульсы ресурсных отраслей к другим элементам региональной системы.

Виды деятельности, выпуск которых наиболее чувствителен к росту выпуска обработки древесины, представлены на рисунке 7.

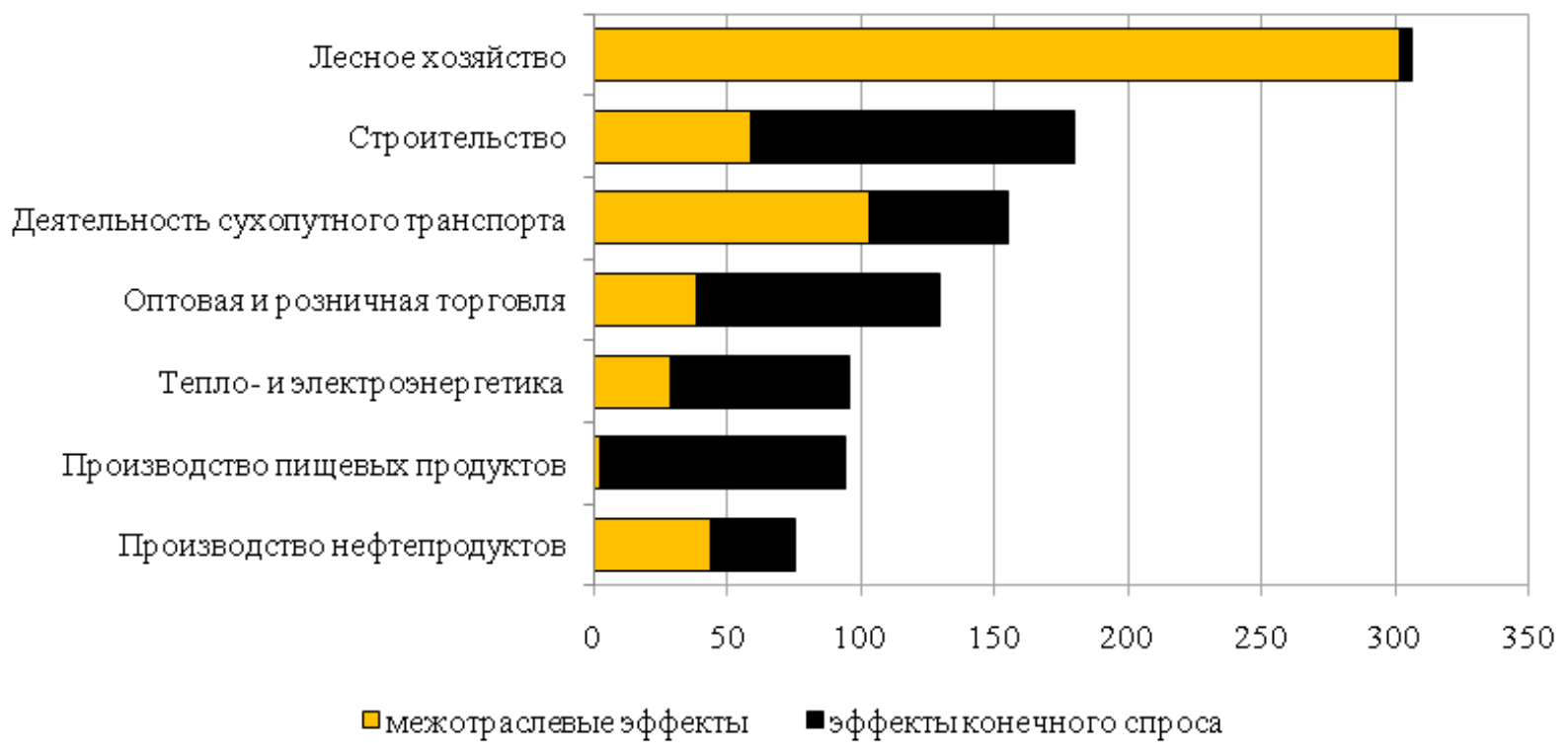

Puc. 7. Реакция видов экономической деятельности на рост выпуска обработки древесины (мультипликаторы МСC), рублей / тыс. рублей.

Источник: рассчитано авторами. 
Из 1 802,6 рубля валового выпуска, генерируемого обработкой древесины, порядка 50\% приходится на семь видов деятельности: лесное хозяйство, строительство, транспорт, торговлю, тепло- и электроэнергетику, производство пищевых продуктов, нефтепереработку. При этом если в лесном хозяйстве эффект формируется исключительно за счёт межотраслевых связей, то в других видах деятельности он является результатом более сложных, разветвлённых связей. Например, в структуре мультипликатора, отражающего влияние обработки древесины на строительство, лишь 9,6\% приходится на прямой межотраслевой эффект, остальные 93,4\% формируются за счёт связей обработки древесины с другими видами деятельности и институциональными секторами. В свою очередь, из этих 93,4\% порядка 20\% генерируется межотраслевыми связями (преимущественно с участием нефтепереработки, тепло- и электроэнергетики, транспорта), порядка 70\% - стимулированием конечного спроса. Детализированные оценки структурных связей обработки древесины с другими видами деятельности представлены в Приложсени 1.

Рост добычи полезных ископаемых (кроме ТЭР) сопровождается прежде всего увеличением выпуска строительства, нефтепереработки, транспорта, торговли, тепло- и электроэнергетики, производства пищевых продуктов, производства транспортных средств и металлургии (рuc. 8).

Значимую долю в структуре мультипликативных эффектов, индуцируемых добычей полезных ископаемых (кроме ТЭР), имеют прямые эффекты (Прилоясение 2). Например, в структуре связей с нефтепереработкой на долю путей без посредников приходится $63,7 \%$, в структуре связей с деятельностью сухопутного транспорта - $18,7 \%$, в структуре связей с металлургией - 40,6\%.

Косвенные же эффекты, индуцируемые добычей полезных ископаемых (кроме ТЭР), распределены («распылены») практически равномерно среди путей с различным составом посредников. Это означает, что добыча полезных ископаемых (кроме

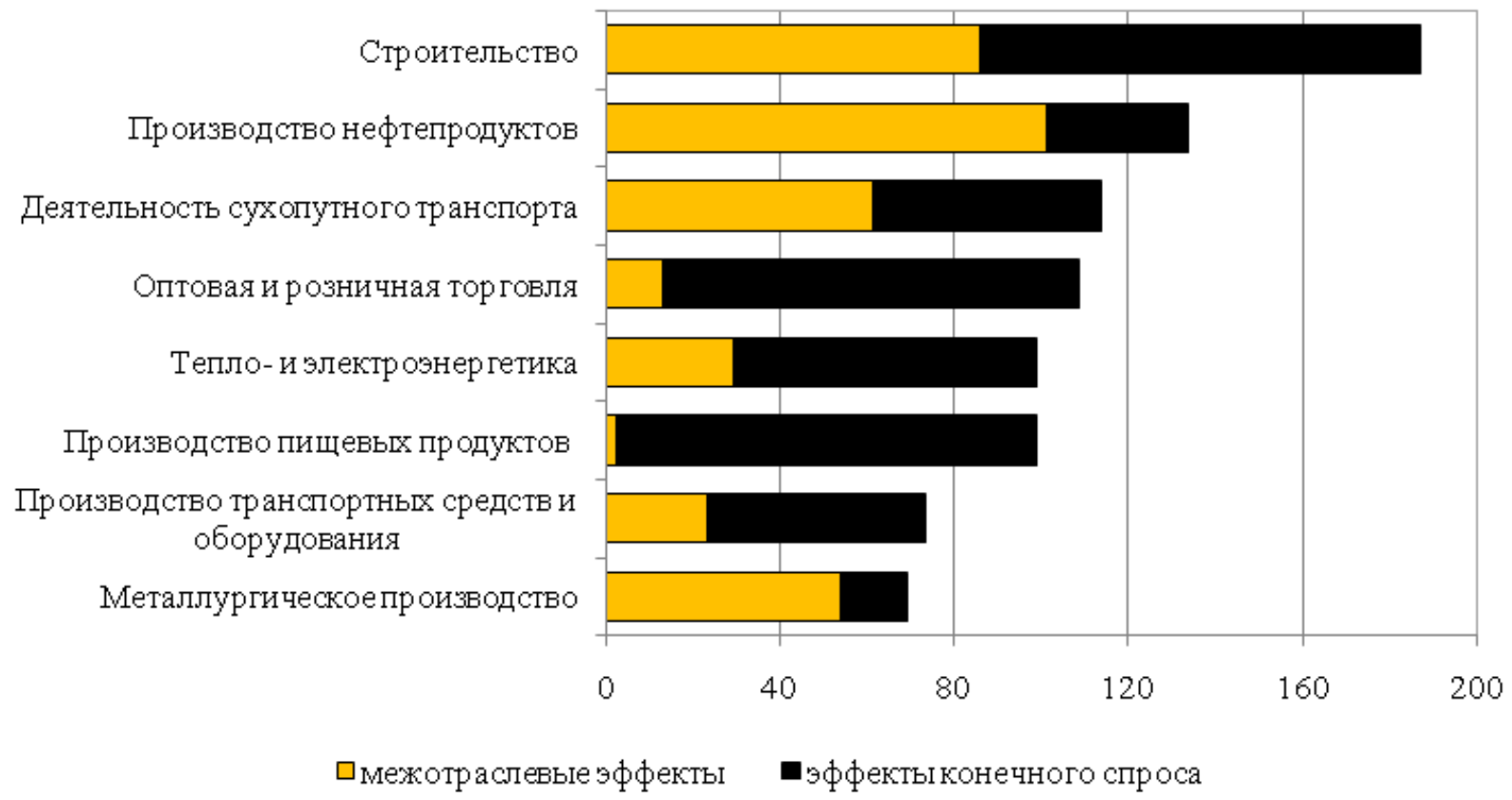

Puc. 8. Реакция видов экономической деятельности на рост добычи полезных ископаемых (кроме ТЭР) (мультипликаторы МСС), рублей / тыс. рублей.

Источник: рассчитано авторами. 
ТЭР) не формирует разветвлённой сети взаимосвязей $\mathrm{c}$ остальной экономикой края. Кроме того, факт значимости межотраслевых эффектов, генерируемых в металлургии и производстве транспортных средств (то есть в производствах, отсутствующих на территории края), указывает на перераспределение части эффектов за пределы региона.

Максимальный отклик на рост выпуска рыболовства и рыбоводства характерен для таких видов деятельности, как строительство, торговля, нефтепереработка, производство пищевых продуктов, транспорт, тепло- и электроэнергетика, операции с недвижимым имуществом, аренда, производство транспортных средств (рис. 9).

Для большей части видов экономической деятельности региональной системы эффект, индуцируемый рыболовством и рыбоводством, формируется преимущественно за счёт стимулирования конечного спроса. Лишь для нефтепереработки в структуре мультипликатора превалирует прямой межотраслевой эффект (Приложение 3). Преобладание эффектов конечного спроса сужает возможности рыболовства и рыбоводства по стимулированию экономики края: фактически, эти возможности замыкаются на третичном секторе, имеющем высокую долю в структуре потребления домашних хозяйств.

Максимальный отклик на рост выпуска лесного хозяйства характерен для таких видов деятельности, как строительство, транспорт, торговля, производство пищевых продуктов, нефтепереработка, тепло- и электроэнергетика, операции с недвижимым имуществом и аренда (рuc. 10).

Прямые эффекты, генерируемые изменением выпуска лесного хозяйства, наиболее значимы для таких видов деятельности, как нефтепереработка и деятельность сухопутного транспорта, которые и являются связующим звеном лесного хозяйства с экономикой региона (Приложение 4).

Виды деятельности, выпуск которых наиболее чувствителен к росту добычи

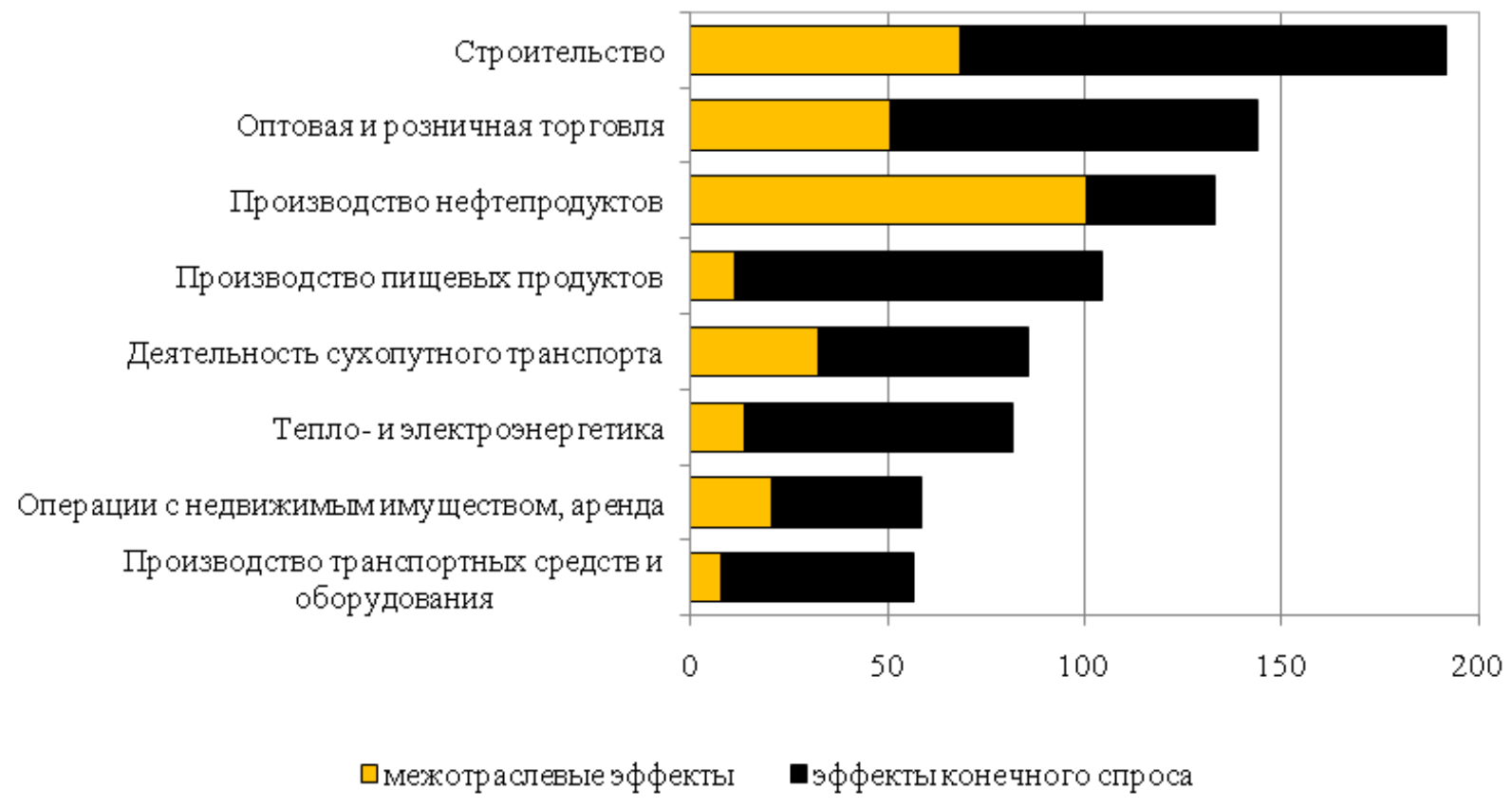

Puc. 9. Реакция видов экономической деятельности на рост выпуска рыболовства и рыбоводства (мультипликаторы МСС), рублей / тыс. рублей.

Источник: рассчитано авторами. 


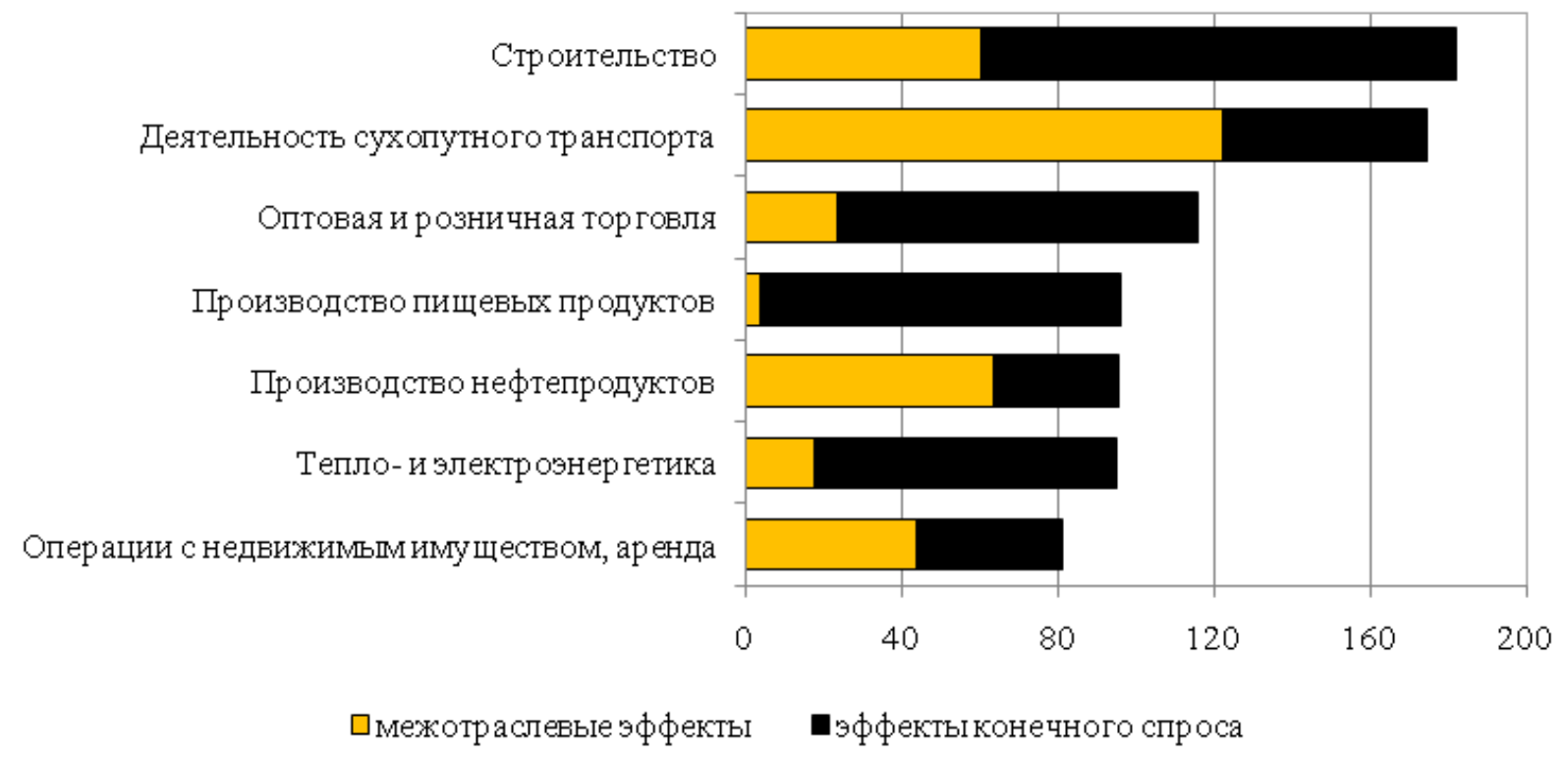

Puc. 10. Реакция видов экономической деятельности на рост выпуска лесного хозяйства (мультипликаторы МСC), рублей / тыс. рублей.

Источник: рассчитано авторами.

ТЭР, представлены на рисунке 11.

Как и в случае рыболовства и рыбоводства, эффект, генерируемый добычей ТЭР, прежде всего формируется за счёт стимулирования конечного спроса. В отношении межотраслевых взаимодействий следует отметить лишь, что они ограничены рамками топливно-энергетического

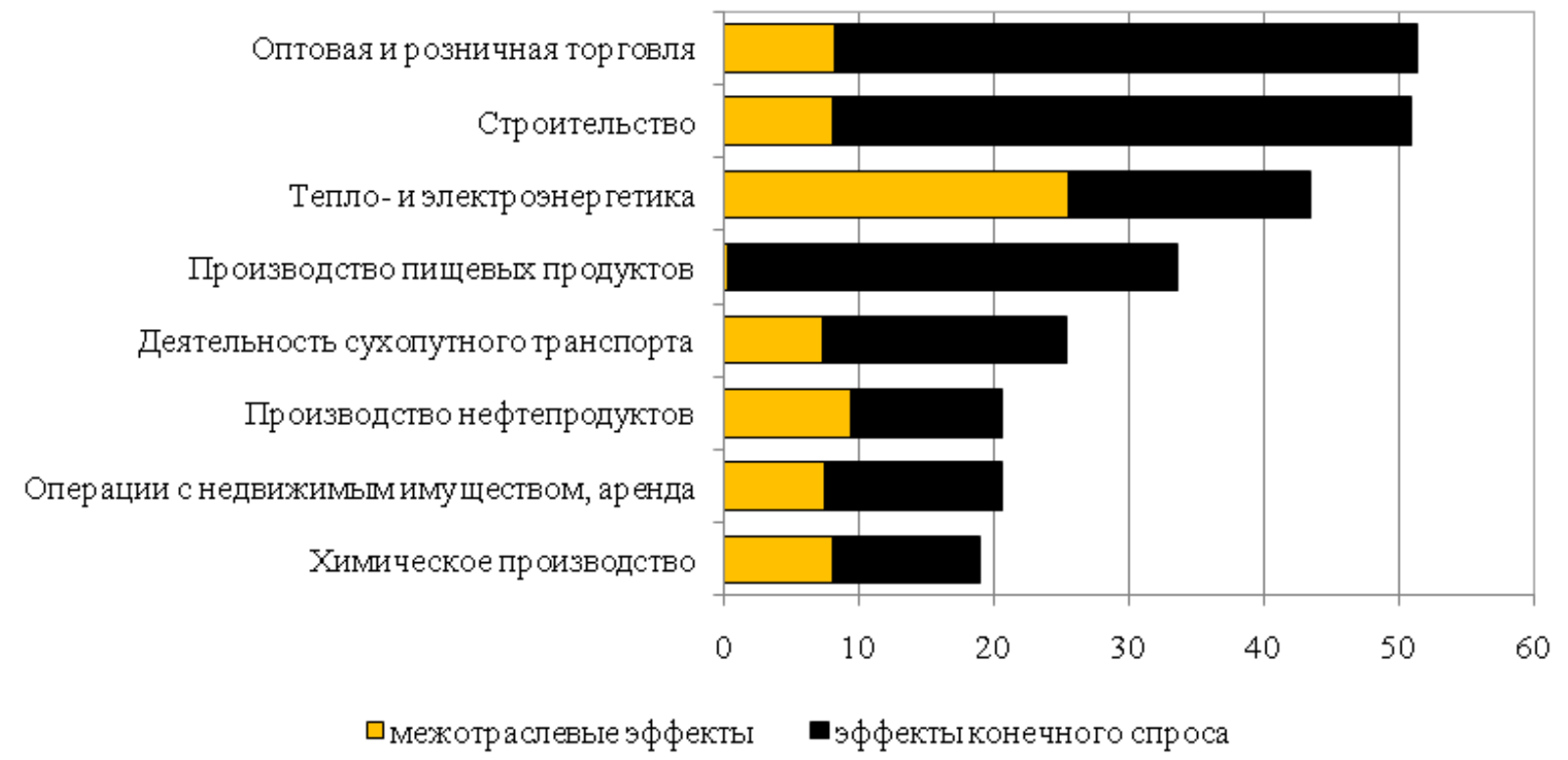

Puc. 11. Реакция видов экономической деятельности на рост добычи ТЭР (мультипликаторы МСC), рублей / тыс. рублей.

Источник: рассчитано авторами. 
комплекса: нефтепереработкой, тепло- и электроэнергетикой (Приложение 5).

Полученные оценки величины и структуры мультипликаторов МСC формируют комплексное представление о роли ресурсного сектора в экономике Хабаровского края, его взаимосвязях с другими отраслями краевой экономики.

\section{3. Перспективные проекты ресурсного сектора и их экономическое значение}

Ресурсный сектор края является объектом активного привлечения инвестиций, поэтому в работе была поставлена задача количественно оценить возможный вклад инвестиционных проектов сектора в экономику Хабаровского края. Для оценки был сформирован «пакет» из инвестиционных проектов, наиболее вероятных к реализации в среднесрочной перспективе (до 2018 года). Суммарный объём финансирования, требуемый на реализацию данных проектов, составляет более 85 млрд рублей (мабл. 8). Увеличение занятости по проектам может составить около 7 тыс. человек.

Для получения количественных оценок возможного вклада инвестиционных проектов ресурсного сектора в экономику Хабаровского края были рассчитаны прямые эффекты от реализации проектов, выражающиеся в приросте валового регионального продукта и увеличении налоговых поступлений в бюджеты разных уровней. Оценки базировались на методике, разработанной в ИЭиОПП СО РАН $[5 ; 8]$, которая предполагает «... погружение проектных данных в систему макропараметров социально-экономического развития региона в фиксированном году» [5, c. 101].

В расчётах использовались две группы показателей: исходные показатели инвестиционных проектов (объём инвестиций в основной капитал, срок окупаемости) и фоновые показатели, определяемые на основе официальных статистических данных (мабл. 9).

Таблица 8

Характеристика инвестиционных проектов ресурсного сектора в Хабаровском крае

\begin{tabular}{|l|c|c|c|c|c|}
\hline \multicolumn{1}{|c|}{ Показатель } & Добыча ТЭР & $\begin{array}{c}\text { Рыболовство } \\
\text { и рыбовод- } \\
\text { ство }\end{array}$ & $\begin{array}{c}\text { Добыча } \\
\text { полезных } \\
\text { ископаемых } \\
\text { (кроме ТЭР) }\end{array}$ & $\begin{array}{c}\text { Обработка } \\
\text { древесины }\end{array}$ & Всего \\
\hline Количество проектов & 1 & 7 & 8 & 5 & 21 \\
\hline $\begin{array}{l}\text { Инвестиции в основ- } \\
\text { ной капитал, млрд } \\
\text { рублей }\end{array}$ & 17,0 & 1,8 & 36,5 & 29,8 & 85,1 \\
\hline Срок окупаемости, лет & 7,1 & 8,0 & 6,0 & 8,3 & - \\
\hline $\begin{array}{l}\text { Численность занятых, } \\
\text { человек }\end{array}$ & 300 & 232 & 4198 & 2092 & 6822 \\
\hline
\end{tabular}

Источники: составлено на основании данных Основных направлений развития лесной отрасли Хабаровского края на 2013-2015 годы и на период до 2020 г. (постановление Правительства Хабаровского края № 266-пр от 08 августа 2012 г.), Государственной целевой программы Хабаровского края «Развитие рыбохозяйственного комплекса Хабаровского края» (постановление Правительства Хабаровского края № 117-пр от 17 апреля 2012 г.), материалов Министерства экономического развития и внешних связей, комитета Правительства края по развитию топливно-энергетического комплекса, комитета лесной промышленности Министерства природных ресурсов края и управления недропользования Министерства природных ресурсов края. 
Таблица 9

Значения фоновых показателей для ресурсных отраслей Хабаровского края в 2011-2012 гг.

\begin{tabular}{|l|c|c|c|c|}
\hline \multicolumn{1}{|c|}{ Показатель } & Добыча ТЭР & $\begin{array}{c}\text { Рыболовство, } \\
\text { рыбоводство }\end{array}$ & $\begin{array}{c}\text { Добыча } \\
\text { полезных } \\
\text { (кроме ТЭР) }\end{array}$ & $\begin{array}{c}\text { Обработка } \\
\text { древесины }\end{array}$ \\
\hline Фондоотдача & 1,4 & 2,9 & 1,9 & 1,1 \\
\hline $\begin{array}{l}\text { Выпуск товаров и услуг, } \\
\text { млн рублей }\end{array}$ & 8136,5 & 6420,7 & 38525,7 & $20493,852^{*}$ \\
\hline $\begin{array}{l}\text { Объем фондов в 2012 г., } \\
\text { млн рублей }\end{array}$ & 5692,6 & 2180,3 & 19834,7 & $18991,185^{*}$ \\
\hline $\begin{array}{l}\text { Среднемесячная заработная } \\
\text { плата, рублей }\end{array}$ & 38496,1 & 26288,3 & 43824,0 & 16120 \\
\hline $\begin{array}{l}\text { Доля добавленной стоимо- } \\
\text { сти в валовом выпуске, \% }\end{array}$ & $60,2 * *$ & 47,3 & $60,2 * *$ & $33,4 * * *$ \\
\hline $\begin{array}{l}\text { Расходы на оплату труда, } \\
\text { млн рублей }\end{array}$ & 1024,2 & 938,0 & 5477,4 & 273,86 \\
\hline $\begin{array}{l}\text { Страховые взносы в Пенсион- } \\
\text { ный фонд, ФСС, ФФОМС, }\end{array}$ & 290,5 & 222,9 & 1233,7 & 70,97 \\
\hline ТФОМС, млн рублей
\end{tabular}

Примечания: * данные по сумме видов деятельности «Лесное хозяйство, лесозаготовки и предоставление услуг в этой области» и «Обработка древесины и производство изделий из дерева»;

** доля добавленной стоимости в валовом выпуске предполагалась равной доле добычи полезных ископаемых;

*** доля добавленной стоимости в валовом выпуске принималась равной доле обрабатывающих производств.

Источники: Основные фонды организаций Хабаровского края в 2012 году: стат. бюллетень. Хабаровск: Хабаровскстат. 2013. С. 6-8; Региональные счета Хабаровского края: стат. сб. Хабаровск: Хабаровскстат. 2013. С. 13; Рыбопромышленный комплекс края: стат. сб. Хабаровск: Хабаровскстат. 2012. С. 10-14; отчётность Федеральной налоговой службы Хабаровского края (Форма № 1-НОМ за 2012 гг.).

В основе расчётов при восстановлении недостающих показателей инвестиционных проектов (валовой прибыли, объёма производства, валовой добавленной стоимости, налоговых отчислений в бюджет) лежали «две основные, предельно устой- чивые и содержательные пропорции, обусловливающие воспроизводство и экономический рост в регионах, - производительность труда и фондоотдача» [5, с. 103]. Валовая прибыль оценивалась на основе объёма инвестиций и срока их окупаемо- 
сти, объёмы производства - на основе значений общеотраслевой фондоотдачи, валовая добавленная стоимость - на основе среднеотраслевой доли валовой добавленной стоимости в валовом выпуске, налоговые отчисления в бюджеты всех уровней на основе данных о налоговых доходах бюджетов и нормативных положений Налогового кодекса [6, с. 180-182].

Проведённый расчёт прямых эффектов от реализации «пакета» проектов в ресурсном секторе показал, что возможное увеличение выпуска продукции в секторе составит 132,7 млрд рублей. Добавленная стоимость оценивается на уровне 70,6 млрд рублей, что обеспечит прирост ВРП в размере $16,3 \%$ относительно уровня 2012 г. Общая сумма налоговых поступлений ожидается в размере 4,1 млрд рублей (табл. 10). там добычи полезных ископаемых, так и ожидаемым масштабом инвестиций (63\% от суммарного объёма инвестиций по пакету проектов).

Для оценки полных эффектов от реализации инвестиционных проектов ${ }^{1}$ были использованы данные по объёмам производства и значения мультипликаторов МСC (табл. 11).

Анализ полученных эффектов показал, что:

- прямой рост физических объёмов производства в обработке древесины в размере 32,1 млрд рублей индуцирует прирост валового выпуска в регионе в размере 57,9 млрд рублей (в том числе 1,1 млрд рублей в самой отрасли); соответственно, 70,9 млрд рублей в добыче полезных ископаемых (кроме ТЭР) - прирост валового

Таблица 10

Прямые эффекты от реализации инвестиционных проектов в ресурсном секторе Хабаровского края, млрд рублей

\begin{tabular}{|l|c|c|c|c|c|}
\hline \multicolumn{1}{|c|}{ Показатель } & Добыча ТЭР & $\begin{array}{c}\text { Рыболовство } \\
\text { и рыбовод- } \\
\text { ство }\end{array}$ & $\begin{array}{c}\text { Добыча } \\
\text { полезных } \\
\text { ископаемых } \\
\text { (кроме ТЭР) }\end{array}$ & $\begin{array}{c}\text { Обработка } \\
\text { древесины }\end{array}$ & Всего \\
\hline Объем производства & 24,3 & 5,4 & 70,9 & 32,1 & 132,7 \\
\hline $\begin{array}{l}\text { Добавленная стои- } \\
\text { мость }\end{array}$ & 14,6 & 2,5 & 42,7 & 10,7 & 70,6 \\
\hline $\begin{array}{l}\text { Поступления в бюдже- } \\
\text { ты всех уровней и це- } \\
\text { левые фонды }\end{array}$ & 0,6 & 0,1 & 2,4 & 1,0 & 4,1 \\
\hline
\end{tabular}

Источник: рассчитано авторами.

Анализ инвестиционных проектов свидетельствует, что максимальные эффекты ожидаются от проектов по добыче полезных ископаемых, обеспечивающих более $80 \%$ суммарного прироста ВРП после реализации пакета проектов и 70\% суммарного прироста доходов бюджетов всех уровней. Это обусловлено как более высоким уровнем фондоотдачи по проек- выпуска в регионе в размере 116,8 млрд рублей (в том числе 8,6 млрд рублей в самой отрасли); 5,4 млрд рублей в рыболовстве и рыбоводстве - прирост валового выпуска в регионе в размере 8,5 млрд руб-

\footnotetext{
${ }^{1}$ В данном случае под полными эффектами понимались эффекты, которые могут быть получены после выхода производства в отраслях ресурсного сектора на проектные мощности.
} 
Таблица 11

Полные эффекты от реализации инвестиционных проектов в ресурсном секторе

Хабаровского края, млн рублей

\begin{tabular}{|c|c|c|c|c|}
\hline Показатель & $\begin{array}{l}\text { Обработка } \\
\text { древесины }\end{array}$ & $\begin{array}{c}\text { Добыча } \\
\text { полезных иско- } \\
\text { паемых (кроме } \\
\text { ТЭР) }\end{array}$ & $\begin{array}{c}\text { Рыболовство } \\
\text { и рыбоводство }\end{array}$ & $\begin{array}{l}\text { Добыча } \\
\text { ТЭР }\end{array}$ \\
\hline $\begin{array}{l}\text { Объём выпуска, соответствующий } \\
\text { проектной мощности }\end{array}$ & 32130,8 & 70918,5 & 5365,7 & 24298,2 \\
\hline $\begin{array}{l}\text { Прирост валового выпуска в } \\
\text { регионе }\end{array}$ & 57919,6 & 116758,8 & 8529,7 & 12350,8 \\
\hline \multicolumn{5}{|l|}{ в том числе } \\
\hline Строительство & 5779,8 & 13279,8 & 1029,8 & 1236,6 \\
\hline Производство нефтепродуктов & 2435,5 & 9500,8 & 713,1 & 503,2 \\
\hline $\begin{array}{l}\text { Деятельность сухопутного транс- } \\
\text { порта }\end{array}$ & 4986,1 & 8064,3 & 459,1 & 615,8 \\
\hline Тепло- и электроэнергетика & 3066,5 & 7008,8 & 438,8 & 1057,4 \\
\hline $\begin{array}{l}\text { Оптовая и розничная торговля, } \\
\text { ремонт }\end{array}$ & 4172,8 & 7707,8 & 771,2 & 1247,3 \\
\hline Прирост доходов в регионе & 40091,7 & 89473,0 & 6867,8 & 10488,5 \\
\hline \multicolumn{5}{|l|}{ в том числе } \\
\hline Домашние хозяйства & 21157,8 & 49220,3 & 3604,4 & 5850,0 \\
\hline Реальный сектор & 13813,9 & 28496,0 & 2389,6 & 3247,1 \\
\hline Региональное правительство & 5120,0 & 11756,7 & 873,8 & 1391,4 \\
\hline
\end{tabular}

Источник: рассчитано авторами.

лей (в том числе 500 млн рублей в самой отрасли); 24,3 млрд рублей в добыче ТЭР прирост валового выпуска в регионе в размере 12,4 млрд рублей (в том числе 1 млрд рублей в самой отрасли);

- разница в значениях мультипликатора МСC, синтезирующего весь комплекс взаимосвязей региональной системы, и фондоотдачи, отражающей прямой эффект отрасли, максимальна для обработки древесины. Это означает, что эффективность деревообработки необходимо рассматривать с позиций функционирования регионального производственного комплекса в целом, учитывая не только её прямые, но и косвенные связи с другими отраслями.

\section{Заключение}

Результаты проведённого исследование роли ресурсного сектора в экономике Хабаровского края позволяют сделать следующие выводы.

С точки зрения прямого вклада в экономику края сектор является значимым и достаточно эффективным: при доле в численности занятых всего 4,5\% он обеспечивает более трети промышленной продукции, 10-12\% инвестиций и налоговых поступлений в крае, практически половину экспорта.

С точки зрения взаимосвязей с другими отраслями экономической системы 
края для ресурсного сектора характерны две черты.

Во-первых, узость межотраслевых связей (то есть небольшое количество отраслей реагируют на импульсы ресурсного сектора).

Во-вторых, невысокий уровень дифференциации видов деятельности, имеющих наиболее тесные связи с различными элементами ресурсного сектора края (то есть отраслевая структура ресурсного сектора не влияет на состав получателей импульса: лидерами являются инфраструктурные элементы - строительство, транспорт, торговля).

Такие характеристики обусловлены структурой ресурсного сектора края, а именно преобладанием сырьевых производств и ориентацией продукции сектора на экспорт.

Для экономики Хабаровского края в целом важны и величина, и структурное соотношение всего спектра мультипликативных эффектов, формируемых ресурсным сектором: и межотраслевых, и конечного спроса. Межотраслевые эффекты стимулируют развитие отраслей экономики, оказывая влияние на формирование и изменение «структурного ландшафта» экономической системы. В условиях Хабаровского края значимые межотраслевые эффекты генерируют добыча полезных ископаемых (кроме ТЭР) и обработка древесины. Эффекты конечного спроса связаны с ростом доходов институциональных секторов и стимулированием развития преимущественно третичного сектора. К отраслям ресурсного сектора Хабаровского края с доминированием эффектов конечного спроса в структуре мультипликаторов относятся рыболовство, лесное хозяйство и добыча ТЭР.

Для ресурсных комплексов, не имеющих в своей структуре перерабатывающих мощностей на территории Хабаровского края, степень влияния на экономику значительно зависит от их масштаба.
Пример: добыча полезных ископаемых (кроме ТЭР) и добыча ТЭР. Если первый вид деятельности имеет достаточно высокий мультипликативный эффект, то есть является драйвером для ряда отраслей (по крайней мере, инфраструктурных), то второй является практически автаркичным с точки зрения воздействия на формирование и изменение структуры экономики региона.

На фоне весьма ограниченных возможностей экстенсивного развития ресурсного сектора перспективной себя показала обработка древесины (даже при пока примитивной её структуре). Имея в разы меньший масштаб производства по сравнению с добычей полезных ископаемых (кроме ТЭР), обработка древесины является лидером по величине мультипликативного эффекта.

Полученные системные оценки количественно подтвердили, что ключевыми условиями роста экономической отдачи ресурсного сектора Хабаровского края являются воспроизводство сырьевой базы отраслей и активное формирование перерабатывающих производств в структуре ресурсного сектора края. 
Приложение 1

Структура связей обработки древесины с другими видами экономической деятельности

\begin{tabular}{|c|c|c|c|c|}
\hline $\begin{array}{c}\text { Вид } \\
\text { экономической } \\
\text { деятельности }\end{array}$ & $\begin{array}{c}\text { Мультиплика- } \\
\text { тор, рублей / } \\
\text { тыс. рублей }\end{array}$ & $\begin{array}{c}\text { Элементарные } \\
\text { пути* }\end{array}$ & $\begin{array}{c}\text { Общее влияние } \\
\text { пути, рублей / тыс. } \\
\text { рублей }\end{array}$ & $\begin{array}{c}\text { Доля общего влияния пути } \\
\text { в мультипликаторе, \% }\end{array}$ \\
\hline \multirow{6}{*}{ Строительство } & \multirow{6}{*}{179,9} & 1 & 17,3 & 9,6 \\
\hline & & 2 & 6,3 & 3,5 \\
\hline & & 3 & 8,5 & 4,7 \\
\hline & & 4 & 16,0 & 8,9 \\
\hline & & 5 & 23,9 & 13,3 \\
\hline & & 6 & 17,8 & 9,9 \\
\hline \multirow{9}{*}{$\begin{array}{l}\text { Тепло- и электро- } \\
\text { энергетика }\end{array}$} & \multirow{9}{*}{95,4} & 7 & 11,5 & 12,1 \\
\hline & & 8 & 3,1 & 3,2 \\
\hline & & 9 & 3,9 & 4,1 \\
\hline & & 10 & 8,4 & 8,8 \\
\hline & & 11 & 11,6 & 12,2 \\
\hline & & 12 & 4,5 & 4,7 \\
\hline & & 13 & 5,2 & 5,4 \\
\hline & & 14 & 3,1 & 3,3 \\
\hline & & 15 & 2,2 & 2,3 \\
\hline \multirow{6}{*}{$\begin{array}{l}\text { Производство } \\
\text { нефтепродуктов }\end{array}$} & \multirow{6}{*}{75,8} & 16 & 7,8 & 10,3 \\
\hline & & 17 & 24,9 & 31,5 \\
\hline & & 18 & 4,1 & 5,4 \\
\hline & & 19 & 5,8 & 7,7 \\
\hline & & 20 & 4,5 & 5,9 \\
\hline & & 21 & 3,3 & 4,3 \\
\hline
\end{tabular}

Примечание: * 1) обработка древесины - строительство; 2) обработка древесины - производство нефтепродуктов - строительство; 3) обработка древесины - тепло- и электроэнергетика - строительство; 4) обработка древесины - деятельность сухопутного транспорта - строительство; 5) обработка древесины - фактор капитал реальный сектор - домашние хозяйства - строительство; 6) обработка древесины - фактор капитал - реальный сектор - строительство; 7) обработка древесины - тепло- и электроэнергетика; 8) обработка древесины - издательская и полиграфическая деятельность - тепло- и электроэнергетика; 9) обработка древесины - производство нефтепродуктов - тепло- и электроэнергетика; 10) обработка древесины - лесное хозяйство - деятельность сухопутного транспорта - тело- и электроэнергетика; 11) обработка древесины - фактор капитал - реальный сектор - домашние хозяйства - тепло- и электроэнергетика; 12) обработка древесины - фактор капитал - реальный сектор - тепло- и электроэнергетика; 13) обработка древесины - фактор труд - домашние хозяйства тепло- и электроэнергетика; 14) обработка древесины - фактор капитал - реальный сектор - домашние хозяйства - производство нефтепродуктов - тепло- и электроэнергетика; 15) обработка древесины - фактор капитал - реальный сектор - домашние хозяйства - образование - тепло- и электроэнергетика; 16) обработка древесины - производство нефтепродуктов; 17) обработка древесины - лесное хозяйство - производство нефтепродуктов; 18) обработка древесины - деятельность сухопутного транспорта - производство нефтепродуктов; 19) обработка древесины - тепло- и электроэнергетика - производство нефтепродуктов; 20) обработка древесины фактор капитал - реальный сектор - домашние хозяйства - производство нефтепродуктов; 21) обработка древесины - фактор капитал - реальный сектор - производство нефтепродуктов.

Источник: рассчитано авторами. 
Приложение 2

\section{Структура связей добычи полезных ископаемых (кроме ТЭР) с} другими видами экономической деятельности

\begin{tabular}{|c|c|c|c|c|}
\hline $\begin{array}{c}\text { Вид } \\
\text { экономической } \\
\text { деятельности }\end{array}$ & $\begin{array}{c}\text { Мультиплика- } \\
\text { тор, рублей / } \\
\text { тыс. рублей }\end{array}$ & $\begin{array}{c}\text { Элементарные } \\
\text { пути* }\end{array}$ & $\begin{array}{c}\text { Общее влияние } \\
\text { пути, рублей / тыс. } \\
\text { рублей }\end{array}$ & $\begin{array}{c}\text { Доля общего влияния пути } \\
\text { в мультипликаторе, \% }\end{array}$ \\
\hline \multirow{8}{*}{$\begin{array}{c}\text { Производство } \\
\text { нефтепродуктов }\end{array}$} & \multirow{8}{*}{134,0} & 1 & 85,3 & 63,7 \\
\hline & & 2 & 4,4 & 3,3 \\
\hline & & 3 & 2,8 & 2,1 \\
\hline & & 4 & 2,7 & 2,0 \\
\hline & & 5 & 6,0 & 4,5 \\
\hline & & 6 & 5,0 & 3,7 \\
\hline & & 7 & 3,1 & 2,3 \\
\hline & & 8 & 3,9 & 2,9 \\
\hline \multirow{6}{*}{$\begin{array}{l}\text { Деятельность } \\
\text { сухопутного } \\
\text { транспорта }\end{array}$} & \multirow{6}{*}{113,7} & 9 & 21,3 & 18,7 \\
\hline & & 10 & 26,3 & 23,1 \\
\hline & & 11 & 2,2 & 1,9 \\
\hline & & 12 & 5,3 & 4,7 \\
\hline & & 13 & 4,3 & 3,8 \\
\hline & & 14 & 8,4 & 7,4 \\
\hline \multirow{6}{*}{$\begin{array}{c}\text { Металлургическое } \\
\text { производство }\end{array}$} & \multirow{6}{*}{69,4} & 18 & 28,2 & 40,6 \\
\hline & & 19 & 1,5 & 2,1 \\
\hline & & 20 & 2,9 & 4,2 \\
\hline & & 21 & 1,2 & 1,8 \\
\hline & & 22 & 0,8 & 1,1 \\
\hline & & 23 & 1,2 & 1,7 \\
\hline
\end{tabular}

Примечание: * 1) добыча полезных ископаемых, кроме ТЭР (ДПИ-ТЭР) - производство нефтепродуктов; 2) ДПИ-ТЭР - деятельность сухопутного транспорта - производство нефтепродуктов; 3) ДПИ-ТЭР - тепло- и электроэнергетика - производство нефтепродуктов; 4) ДПИ-ТЭР - строительство - производство нефтепродуктов; 5) ДПИ-ТЭР - фактор труд - домашние хозяйства - производство нефтепродуктов; 6) ДПИ-ТЭР фактор капитал - реальный сектор - производство нефтепродуктов; 7) ДПИ-ТЭР - фактор труд - домашние хозяйства - тепло- и электроэнергетика - производство нефтепродуктов; 8) ДПИ-ТЭР - фактор труд - домашние хозяйства - производство транспортных средств и оборудования - производство нефтепродуктов; 9) ДПИТЭР - деятельность сухопутного транспорта; 10) ДПИ-ТЭР - производство нефтепродуктов - деятельность сухопутного транспорта; 11) ДПИ-ТЭР - строительство - деятельность сухопутного транспорта; 12) ДПИТЭР - фактор труд - домашние хозяйства - оптовая и розничная торговля - деятельность сухопутного транспорта; 13) ДПИ-ТЭР - фактор труд - домашние хозяйства - деятельность сухопутного транспорта; 14) ДПИТЭР - фактор капитал - реальный сектор - деятельность сухопутного транспорта; 15) ДПИ-ТЭР - металлургическое производство; 16) ДПИ-ТЭР - тепло- и электроэнергетика - металлургическое производство; 17) ДПИТЭР - производство транспортных средств и оборудования - металлургическое производство; 18) ДПИ-ТЭР строительство - металлургическое производство; 19) ДПИ-ТЭР - фактор труд - домашние хозяйства - строительство - металлургическое производство; 20) ДПИ-ТЭР - фактор труд - домашние хозяйства - производство электронного оборудования, электронного и оптического оборудования - металлургическое производство; 21) ДПИ-ТЭР - фактор труд - домашние хозяйства - производство транспортных средств и оборудования металлургическое производство; 22) ДПИ-ТЭР - фактор капитал - реальный сектор - металлургическое производство; 23) ДПИ-ТЭР - фактор капитал - реальный сектор - производство транспортных средств и оборудования - металлургическое производство.

Источник: рассчитано авторами. 
Приложение 3

Структура связей рыболовства и рыбоводства с другими видами экономической деятельности

\begin{tabular}{|c|c|c|c|c|}
\hline $\begin{array}{c}\text { Вид } \\
\text { экономической } \\
\text { деятельности }\end{array}$ & $\begin{array}{c}\text { Мультиплика- } \\
\text { тор, рублей / } \\
\text { тыс. рублей }\end{array}$ & $\begin{array}{c}\text { Элементарные } \\
\text { пути* }\end{array}$ & $\begin{array}{c}\text { Общее влияние } \\
\text { пути, рублей / тыс. } \\
\text { рублей }\end{array}$ & $\begin{array}{c}\text { Доля общего влияния пути } \\
\text { в мультипликаторе, \% }\end{array}$ \\
\hline \multirow{7}{*}{$\begin{array}{c}\text { Оптовая и } \\
\text { розничная } \\
\text { торговля, } \\
\text { ремонт }\end{array}$} & \multirow{7}{*}{143,7} & 1 & 85,3 & 63,7 \\
\hline & & 2 & 4,4 & 3,3 \\
\hline & & 3 & 2,8 & 2,1 \\
\hline & & 4 & 2,7 & 2,0 \\
\hline & & 5 & 6,0 & 4,5 \\
\hline & & 6 & 5,0 & 3,7 \\
\hline & & 7 & 3,0 & 2,1 \\
\hline \multirow{9}{*}{$\begin{array}{c}\text { Производство } \\
\text { нефтепродуктов }\end{array}$} & \multirow{9}{*}{132,9} & 8 & 84,0 & 63,2 \\
\hline & & 9 & 3,6 & 2,7 \\
\hline & & 10 & 2,4 & 1,8 \\
\hline & & 11 & 2,0 & 1,5 \\
\hline & & 12 & 4,7 & 3,5 \\
\hline & & 13 & 2,5 & 1,9 \\
\hline & & 14 & 3,7 & 2,8 \\
\hline & & 15 & 7,0 & 5,3 \\
\hline & & 16 & 6,5 & 4,9 \\
\hline \multirow{6}{*}{$\begin{array}{c}\text { Производство } \\
\text { транспортных } \\
\text { средств и обору- } \\
\text { дования }\end{array}$} & \multirow{6}{*}{56,5} & 17 & 4,1 & 7,3 \\
\hline & & 18 & 1,2 & 2,1 \\
\hline & & 19 & 1,0 & 1,8 \\
\hline & & 20 & 10,6 & 18,7 \\
\hline & & 21 & 15,5 & 27,5 \\
\hline & & 22 & 3,2 & 5,6 \\
\hline
\end{tabular}

Примечание: * 1) рыболовство, рыбоводство - оптовая и розничная торговля, ремонт; 2) рыболовство, рыбоводство - производство пищевых продуктов - оптовая и розничная торговля, ремонт; 3) рыболовство, рыбоводство - производство нефтепродуктов - оптовая и розничная торговля, ремонт; 4) рыболовство, рыбоводство - фактор труд - домашние хозяйства - оптовая и розничная торговля, ремонт; 5) рыболовство, рыбоводство фактор труд - домашние хозяйства - производство пищевых продуктов - оптовая и розничная торговля, ремонт; 6) рыболовство, рыбоводство - фактор капитал - реальный сектор - домашние хозяйства - оптовая и розничная торговля, ремонт; 7) рыболовство, рыбоводство - фактор капитал - реальный сектор - оптовая и розничная торговля, ремонт; 8) рыболовство, рыбоводство - производство нефтепродуктов; 9) рыболовство, рыбоводство - деятельность сухопутного транспорта - производство нефтепродуктов; 10) рыболовство, рыбоводство - вспомогательная и дополнительная транспортная деятельность - производство нефтепродуктов; 11) рыболовство, рыбоводство - производство машин и оборудования - производство нефтепродуктов; 12) рыболовство, рыбоводство - фактор труд - домашние хозяйства - производство нефтепродуктов; 13) рыболовство, рыбоводство - фактор труд - домашние хозяйства - производство электрооборудования, электронного и оптического оборудования - производство нефтепродуктов; 14) рыболовство, рыбоводство - фактор труд - домашние хозяйства - тепло- и электроэнергетика - производство нефтепродуктов; 15) рыболовство, рыбоводство фактор капитал - реальный сектор - домашние хозяйства - производство нефтепродуктов; 16) рыболовство, рыбоводство - фактор капитал - реальный сектор - производство нефтепродуктов; 17) рыболовство, рыбоводство - производство транспортных средств и оборудования; 18) рыболовство, рыбоводство - деятельность сухопутного транспорта - производство транспортных средств и оборудования; 19) рыболовство, рыбоводство вспомогательная и дополнительная транспортная деятельность - производство транспортных средств и оборудования; 20) рыболовство, рыбоводство - фактор труд - домашние хозяйства - производство транспортных средств и оборудования; 21) рыболовство, рыбоводство - фактор капитал - реальный сектор - домашние хозяйства - производство транспортных средств и оборудования; 22) рыболовство, рыбоводство - фактор капитал - реальный сектор - производство транспортных средств и оборудования.

Источник: рассчитано авторами. 
Приложение 4

Структура связей лесного хозяйства с другими видами экономической деятельности

\begin{tabular}{|c|c|c|c|c|}
\hline $\begin{array}{c}\text { Вид } \\
\text { экономической } \\
\text { деятельности }\end{array}$ & $\begin{array}{c}\text { Мультиплика- } \\
\text { тор, рублей / } \\
\text { тыс. рублей }\end{array}$ & $\begin{array}{c}\text { Элементарные } \\
\text { пути* }\end{array}$ & $\begin{array}{c}\text { Общее влияние } \\
\text { пути, рублей / тыс. } \\
\text { рублей }\end{array}$ & $\begin{array}{c}\text { Доля общего влияния пути } \\
\text { в мультипликаторе, \% }\end{array}$ \\
\hline \multirow{7}{*}{ Строительство } & \multirow{7}{*}{182,0} & 1 & 2,4 & 1,3 \\
\hline & & 2 & 2,7 & 1,5 \\
\hline & & 3 & 18,9 & 10,4 \\
\hline & & 4 & 23,8 & 13,1 \\
\hline & & 5 & 16,7 & 9,2 \\
\hline & & 6 & 11,5 & 6,3 \\
\hline & & 7 & 5,8 & 3,2 \\
\hline \multirow{5}{*}{$\begin{array}{l}\text { Деятельность } \\
\text { сухопутного } \\
\text { транспорта }\end{array}$} & \multirow{5}{*}{174,5} & 8 & 111,0 & 63,6 \\
\hline & & 9 & 5,9 & 3,4 \\
\hline & & 10 & 4,0 & 2,3 \\
\hline & & 11 & 14,5 & 8,3 \\
\hline & & 12 & 3,5 & 2,0 \\
\hline
\end{tabular}

Примечание: * 1) лесное хозяйство - строительство; 2) лесное хозяйство - обработка древесины - строительство; 3) лесное хозяйство - производство нефтепродуктов - строительство; 4) лесное хозяйство - деятельность сухопутного транспорта - строительство; 5) лесное хозяйство - фактор труд - домашние хозяйства - строительство; 6) лесное хозяйство - фактор капитал - реальный сектор - деятельность сухопутного транспорта строительство; 7) лесное хозяйство - фактор капитал - реальный сектор - строительство; 8) лесное хозяйство деятельность сухопутного транспорта; 9) лесное хозяйство - производство нефтепродуктов - деятельность сухопутного транспорта; 10) лесное хозяйство - фактор труд - домашние хозяйства - деятельность сухопутного транспорта; 11) лесное хозяйство - фактор капитал - реальный сектор - деятельность сухопутного транспорта; 12) лесное хозяйство - фактор труд - домашние хозяйства - строительство - деятельность сухопутного транспорта.

Источник: рассчитано авторами. 
Приложение 5

Структура связей добычи ТЭР с другими видами экономической деятельности

\begin{tabular}{|c|c|c|c|c|}
\hline $\begin{array}{c}\text { Вид } \\
\text { экономической } \\
\text { деятельности }\end{array}$ & $\begin{array}{c}\text { Мультиплика- } \\
\text { тор, рублей / } \\
\text { тыс. рублей }\end{array}$ & $\begin{array}{c}\text { Элементарные } \\
\text { пути* }\end{array}$ & $\begin{array}{c}\text { Общее влияние } \\
\text { пути, рублей / тыс. } \\
\text { рублей }\end{array}$ & $\begin{array}{c}\text { Доля общего влияния пути } \\
\text { в мультипликаторе, \% }\end{array}$ \\
\hline \multirow{8}{*}{ Строительство } & \multirow{8}{*}{50,9} & 1 & 2,6 & 5,2 \\
\hline & & 2 & 1,2 & 2,4 \\
\hline & & 3 & 6,2 & 12,1 \\
\hline & & 4 & 0,7 & 1,3 \\
\hline & & 5 & 1,0 & 2,0 \\
\hline & & 6 & 4,3 & 8,5 \\
\hline & & 7 & 0,7 & 1,4 \\
\hline & & 8 & 1,6 & 3,2 \\
\hline \multirow{9}{*}{$\begin{array}{c}\text { Тепло- и электро- } \\
\text { энергетика }\end{array}$} & \multirow{9}{*}{43,5} & 9 & 6,2 & 14,2 \\
\hline & & 10 & 6,0 & 13,7 \\
\hline & & 11 & 1,6 & 3,6 \\
\hline & & 12 & 5,9 & 13,5 \\
\hline & & 13 & 0,9 & 2,1 \\
\hline & & 14 & 0,7 & 1,5 \\
\hline & & 15 & 5,0 & 11,6 \\
\hline & & 16 & 2,4 & 5,5 \\
\hline & & 17 & 0,8 & 1,9 \\
\hline
\end{tabular}

Примечание: * 1) добыча ТЭР - производство нефтепродуктов - строительство; 2) добыча ТЭР - деятельность сухопутного транспорта - строительство; 3) добыча ТЭР - фактор труд - домашние хозяйства - строительство; 4) добыча ТЭР - фактор труд - домашние хозяйства - тепло- и электроэнергетика - строительство; 5) добыча ТЭР - предоставление прочих коммунальных, социальных и персональных услуг - строительство; 6) добыча ТЭР - фактор капитал - реальный сектор - домашние хозяйства - строительство; 7) добыча ТЭР - фактор капитал - реальный сектор - домашние хозяйства - предоставление прочих коммунальных, социальных и персональных услуг - строительство; 8) добыча ТЭР - фактор капитал - реальный сектор - деятельность сухопутного транспорта - строительство; 9) добыча ТЭР - тепло- и электроэнергетика; 10) добыча ТЭР - производство нефтепродуктов - тепло- и электроэнергетика; 11) добыча ТЭР - производство машин и оборудования - теплои электроэнергетика; 12) добыча ТЭР - фактор труд - домашние хозяйства - тепло- и электроэнергетика; 13) добыча ТЭР - фактор труд - домашние хозяйства - производство транспортных средств и оборудования - тепло- и электроэнергетика; 14) добыча ТЭР - фактор труд - домашние хозяйства - образование - тепло- и электроэнергетика; 15) добыча ТЭР - фактор капитал - реальный сектор - домашние хозяйства - тепло- и электроэнергетика; 16) добыча ТЭР - фактор капитал - реальный сектор - тепло- и электроэнергетика; 17) добыча ТЭР - фактор капитал - реальный сектор - домашние хозяйства - производство транспортных средств и оборудования - тепло- и электроэнергетика.

Источник: рассчитано авторами. 


\section{Список литературы}

1. Антонова Н.Е., Шейнгауз А.С. Социальная структура лесных поселков // В кн.: Север: проблемы периферийных территорий / отв. ред. В.Н. Лаженцев. Сыктывкар: Коми НЦ УрО РАН, 2007. С. 153-163.

2. Власюк Л.И., Захарченко Н.Г., Калашни$к о в$ В.Д. Исследование региональных экономических пропорций и мультипликативных эффектов: Хабаровский край // Пространственная экономика. 2012. № 2. С. 44-66.

3. Захарченко Н.Г. Использование матриц социальных счетов в моделировании структуры экономической системы // Пространственная экономика. 2012. № 1. С. 69-89.

4. Захарченко Н.Г., Дёмина О.В. ТЭК в экономике региона: оценка мультипликативных эффектов // Пространственная экономика. 2013. № 1. C. 33-54.

5. Коледа А.В., Суспищьн С.А. Предпроектные обоснования региональных инвестиционных инициатив // Регион: экономика и социология. 2005. № 3. С. 95-113.

6. Ломакина Н.В. Минерально-сырьевой комплекс Дальнего Востока России: потенциал развития / отв. ред. П.А. Минакир; Рос. Акад. Наук, Дальневост. отд-ние, Ин-т экон. исследований. Хабаровск: РИОТИП, 2009. 240 с.

7. Ломакина Н.В., Антонова Н.Е. Современная система природопользования Дальнего Востока: новые тенденции и оценки // Пространственная экономика. 2013. № 3. С. 89107.

8. Суспицын C.A. Подходы к оценке приоритетов региональной инвестиционной политики // Регион: экономика и социология. 2002. № 2. C. 25-44.

\section{References}

1. Antonova N.E. Sheyngauz A.S. Social Structure of Forest Settlements. In: The North: Problems of Outlying Territories. Ed. by V.N. Lazhentsev. Syktyvkar, 2007. Pp. 153-163. (In Russian)

2. Vlasyuk L.I., Zakharchenko N.G., Kalashnikov V.D. Studying Regional Macroeconomic Proportions and Multiplier Effects: Khabarovsk Krai. Prostranstvennaya economika [Spatial Economics]. 2012. No. 2. Pp. 44-66. (In Russian)
3. Zakharchenko N.G. Using Social Accounting Matrices in Modeling the Structure of Economic System. Prostranstvennaya economika [Spatial Economics]. 2012. No. 1. Pp. 69-89. (In Russian)

4. Zakharchenko N.G., Dyomina O.V. The Role of the Energy Sector in Regional Economy: Estimating Multiplicative Effects. Prostranstvennaya economika [Spatial Economics]. 2013. No. 1. Pp. 33-54. (In Russian)

5. Koleda A.V., Suspitsin S.A. Pre-project Evaluations of Regional Investment Initiatives. Region: ekonomika i sotsiologiya [Region: Economics \& Sociology]. 2005. No. 3. Pp. 95-113. (In Russian)

6. Lomakina N.V. The Mineral Resources Sector of the Russian Far East: the Development potential. Ed. by P.A. Minakir. Khabarovsk, 2009. 240 p. (In Russian)

7. Lomakina N.V., Antonova N.E. Modern System of Nature Management of the Russian Far East: New Tendencies and Estimates. Prostranstvennaya economika [Spatial Economics]. 2013. No. 3. Pp. 89-107. (In Russian)

8. Suspitsin S.A. Approaches to the Evaluation of Priorities in Regional Investment Policy. Region: ekonomika i sotsiologiya [Region: Economics \& Sociology]. 2002. No. 2. Pp. 25-44. (In Russian)

\section{Для цุитирования:}

Антонова Н.Е., Дёмина О.В., Захарченко Н.Г., Ломакина Н.В., Сухомиров Г.И. Оценка роли ресурсного сектора в экономике региона: пример Хабаровского края // Регионалистика. 2014. Т. 1. № 2. С. 42-70.

For citing:

Antonova N.E., Dyomina O.V., Zakharchenko N.G., Lomakina N.V., Sukhomirov G.I. Estimating the Resource Sector Role in Regional Economy: The Case of Khabarovsk Krai. Regionalistica [Regionalistics]. 2014. Vol. 1. No. 2. Pp. 42-70. (In Russian) 


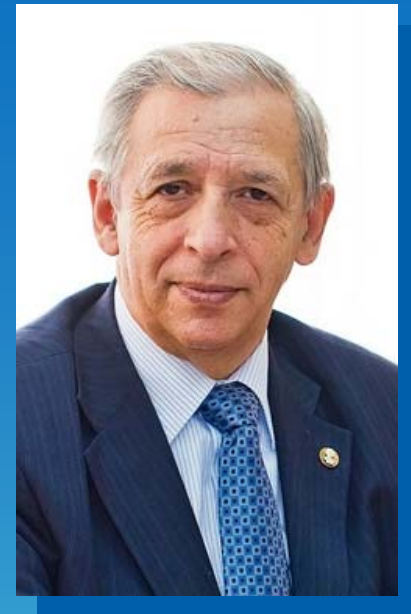

МИНАКИР

Павел

Александрович

Академик, профрессор, доктор экономических наук, директор

Институт экономических исследований ДВО РАН, ул. Тихоокеанская, 153, Хабаровск, Россия, 680042

\section{MINAKIR}

\section{Pavel}

\section{Aleksandrovich}

Academician, professor, doctor of economics, director Economic Research Institute FEB RAS, 153, Tikhookeanskaya Street, Khabarovsk, Russia, 680042

minakir@ecrin.ru

(C) Минакир П.А., 2014

\section{УДК $330+339$}

\section{NEA ECONOMIC INTEGRATION: RUSSIAN PERSPECTIVES}

The article examines specific features of the contemporary Russian economic model. Comparative dynamics of the macroeconomic indicators is analyzed. The assessment of scales and structures of interaction of economy of Russia and the Far East with the countries of the Pacific Rim and Northeast Asia is given. Problems of realizing of a course towards the East Asian integration are shown.

Economic growth, investments, economic cooperation, Northeast Asia, economic model, stagnation, exchange rate, regional development

\section{ЭКОНОМИЧЕСКАЯ ИНТЕГРАЦИЯ В СВА: РОССИЙСКИЕ ПЕРСПЕКТИВЫ}

В статье рассматриваются особенности российской экономической модели на современном этапе. Анализируется сравнительная динамика основных макроэкономических показателей. Проводится оценка масштабов и структур взаимодействия экономики России и Дальнего Востока со странами АТР и Северовосточной Азии. Показаны проблемы реализации стратегического курса на восточноазиатскую интеграцию.

Экономический рост, инвестиции, экономическая кооперачия, Северо-восточная Азия, экономическая модель, стагнация, валютный курс, региональное развитие

This article is prepared on the basis of report for the $23^{\text {rd }}$ annual Northeast Asia Economic Forum.

Работа основана на материалах доклада, подготовленного для 23-го ежегодного Экономического форума Северо-восточной Азии. 


\section{General Strategy}

Since 1997 we could face three variant of «turn to East» policy in USSR/Russia. First one was connected with so called Gorbachev's Pacific maneuver (1987-1990) - I mean not only general declaration about pacific direction for soviet economy, but first lows for foreign investments and joint ventures with special incentives for the Fareastern' economic agents as well as the first State Development program for the Far East region. Second period (1992-1996) was connected with the transformation crisis in Russia, when the orientation to NEA markets had saved timber, fish, metallurgy, food processing industries as well as consumer market. And since 2006 the third period of Pacific integration of Russia in form of trade and investments have begun. It is based on foreign direct investments to the Russian Far East energy sector and enormous internal investments to transit infrastructure.

Up to date we can conclude that in case of trade some optimistic results in the Pacific reorientation were achieved as a minimum from statistical and macroeconomic point of view. Almost $25 \%$ of total Russian export is connecting with the APEC region (figure 1).

And the biggest part of it is the export to NEA countries, around $71 \%$ of the total export to APEC. Though the EU up to date remains the trade partner № 1 for Russia, trade with APEC is growing up very fast (figure 2).

Main part of the Russian trade with NEA as well as with EU is energy products including crude oil and for last 2 years LNG. This is corresponding with general Russian export commodity structure which consists more than on $70 \%$ from energy goods (figure 3).

In future the energy sector of Russian export to the NEA will increase due to two factors. Problems with European energy market for Russian companies is the first. Troubles are connected not only with the modern Ukrainian crisis; it is only an indicator of system problems which include competitive policy of US as well as the desire of the EU itself to minimize the dependence on Russian energy resources' supplies. By the way the Ukrainian crisis from economic point of view can be reviewed as a strategic turning point in case of Russia-NEA economic ties. Economic sanctions declared by US and EU are seeing by Russia as strategic challenge which it look forward to. And main spheres where Russia has to look for new opportunities are not even trade but technological and investment exchange.

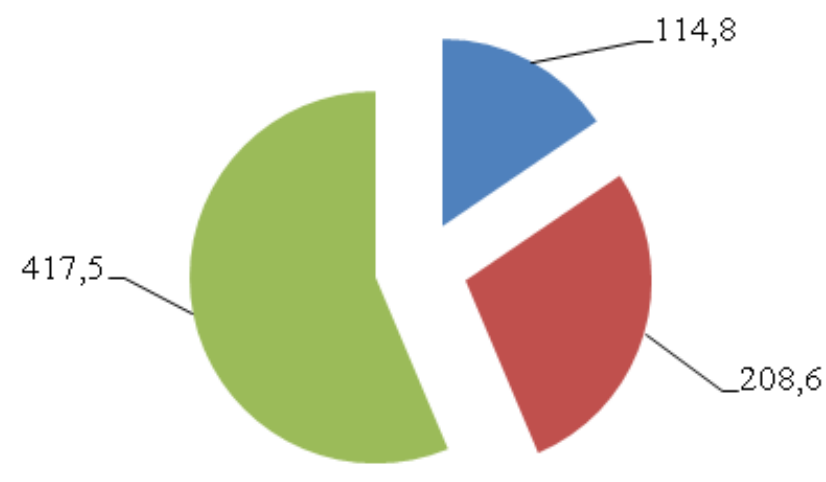

$\because \mathrm{CIS} \quad \square \mathrm{APEC} \quad \square \mathrm{EU}$

Figure 1. Russian Foreign Trade Turnover, 2013, \$ billion 


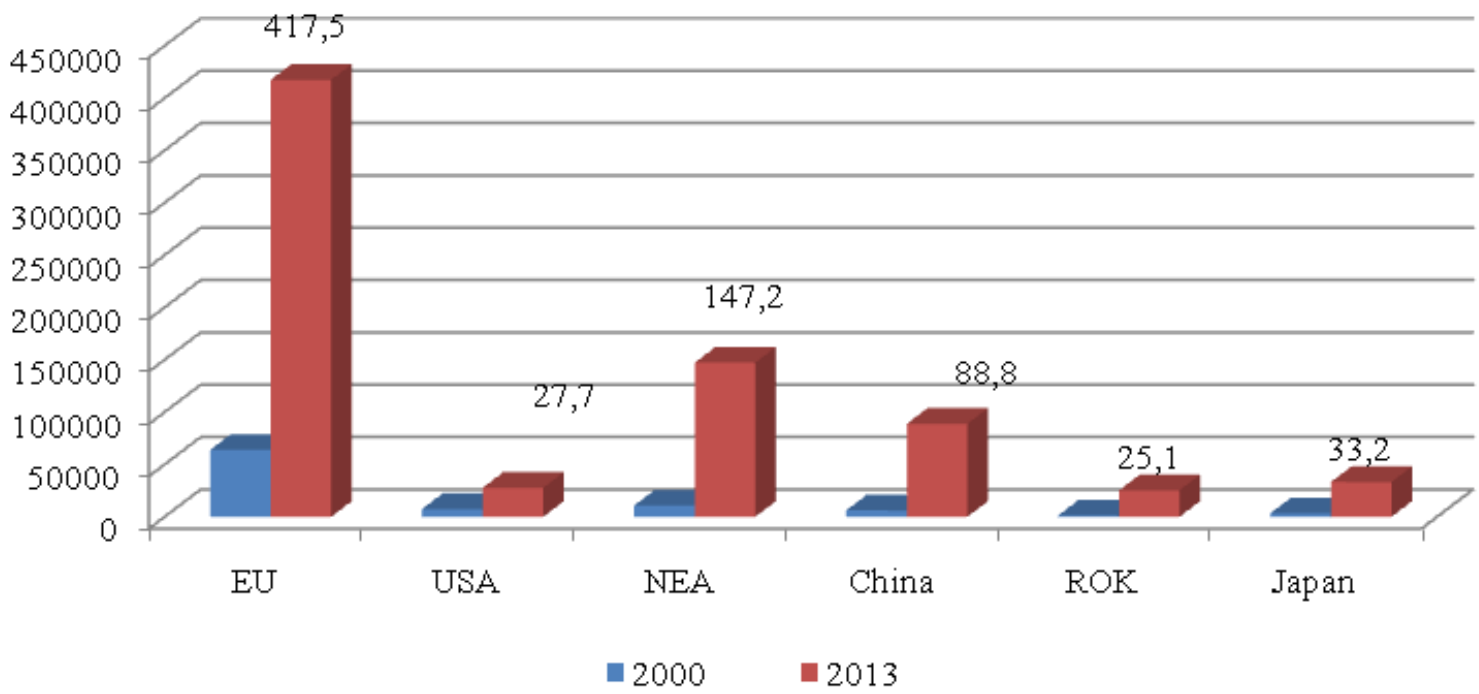

Figure 2. Russian Foreign Trade by sectors/countries, $\$$ billion

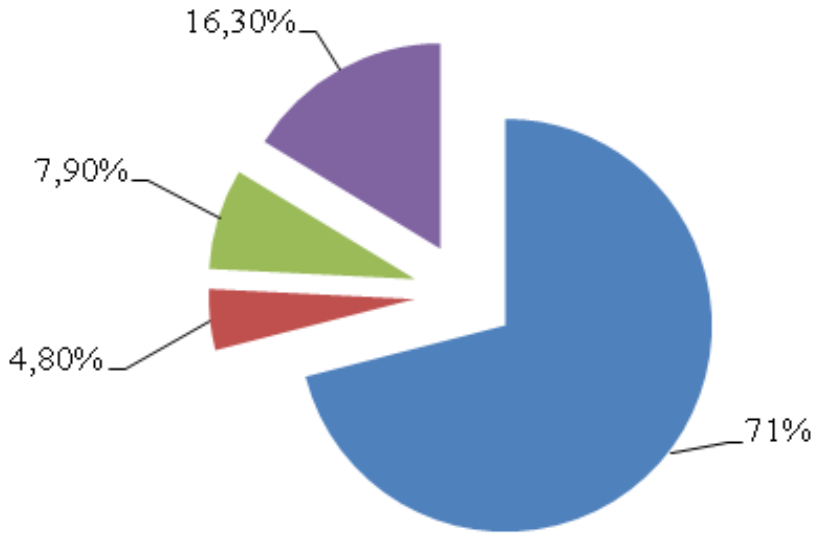

Energy goods $\quad$ Mashinery Metalls -Others

Figure 3. Russian export commodity structure, 2013

Though the average ratio «investment/GDP» in Russia is not enough high for developing economy (around 20-22\%) and main «growth engine» is internal and external demand [3], investments are playing very important role first of all in energy and extracting sectors of the Russian economy which provide main part of federal budget incomes, more than $60 \%$ (table 1).

Since 2000 the volume of foreign in- vestments to Russia increased more than 22 times (figure 4) due to an import substitution development after the 1998 financial crisis and opening of financial market.

Direct foreign investments consists only $2-3 \%$ of the total volume of investments to fixed capital in Russia (figure 5), but the most important thing is so called «other investments» (loans, securities and so on), which used for financing of domestic investments. 
Table 1

Russian Federal Budget Incomes, 2013, trillion rubles

\begin{tabular}{|l|r|}
\hline Total Incomes & 12020 \\
\hline VAT & 3575 \\
\hline Natural Resources Taxes & 2544 \\
\hline Incomes from Foreign Economic Activity & 4662 \\
\hline Others & 1239 \\
\hline
\end{tabular}

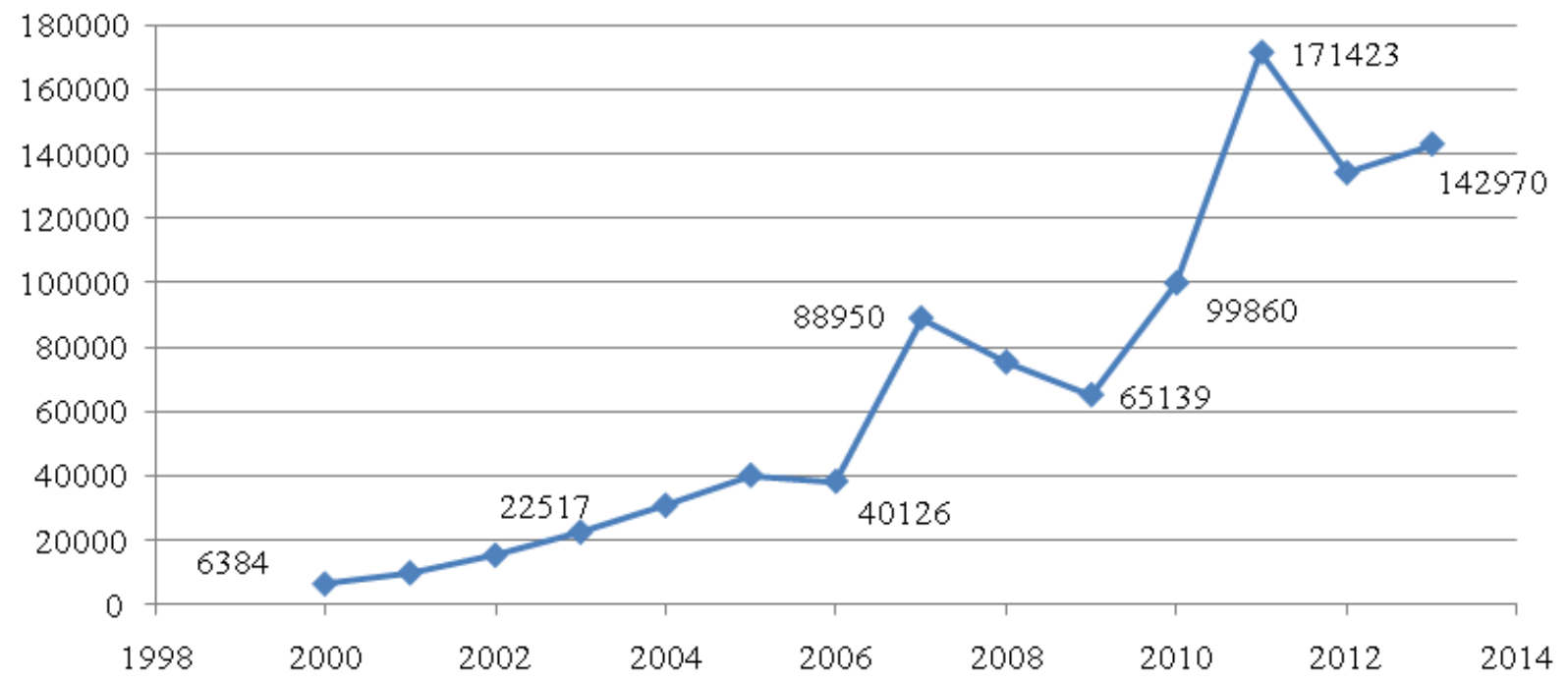

Figure 4. Foreign Investments in Russia, \$ million

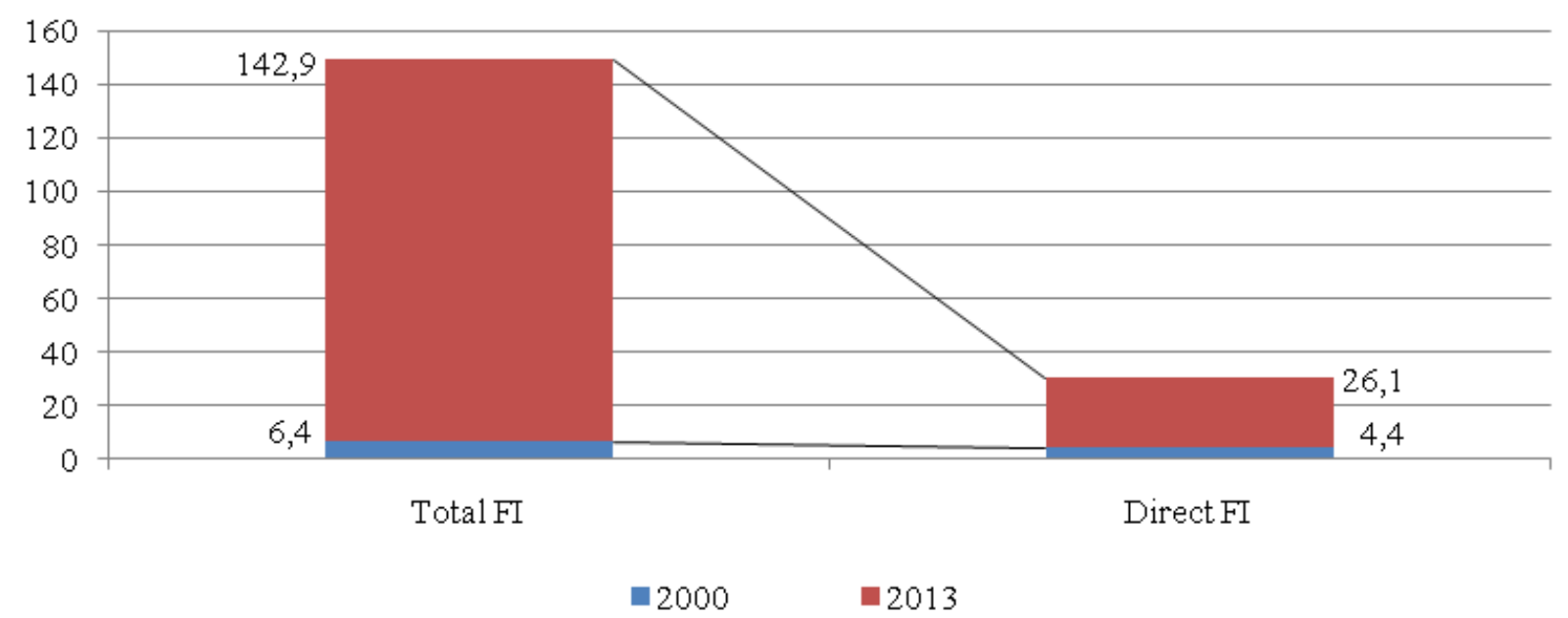

Figure 5. Foreign Investments structure, $\$$ billion

Note: Russian investments to fixed capital - \$1 145 billion (2013) 
There share is $12-14 \%$ of the total Russian investments to the internal economy.

It means that Russia need to face the serious financial challenge from the Western sanctions and has to look for new financial sources not only because of possible troubles with current and future investment financing but also for supporting accumulating external debts services. The volume of Russian corporate external debt is not extremely but enough high, about $29 \%$ of GDP and $115 \%$ of national gold and currencies reserves (table 2). One of the alternative sources for external investment financing is the NEA and not only for the «sanction period» but after it too. By the way speaking about NEA in this context we must take into account mainly China due to uncertain position of Japan and complicated situation for ROK.

The second possible direction of external finance sources' diversification is BRICS which is one of the world's economic score concentrated $20-22 \%$ of the world GDP (figure 6). But if general economic potential of this alliance is enough high, it's financial and institutional potential is not so optimistic now. During last BRICS meeting in Brazil first step towards constructing joint financial institution were done but it is very long way and first result on it maybe would be seen only in future.

\section{Regional Instrument}

Since the mid of 1960s USSR/Russia used the Fareastern region as the main base and channel on the way to APEC and NEA. Until 2004 this region was a real main base for the trade and investment cooperation with NEA, giving around $75 \%$ of total Russian trade turnover and $80 \%$ of capital transactions. Now the situation has changed. After constructing the Trans Siberian oil pipeline and other elements of hard infrastructure including sea port and railways reconstruction such regions as Siberia and Ural began to play the growing role in Russia-NEA cooperation game. The Russian Far East became mainly transit territory for Russian trade with NEA

Table 2

External Debt of Russia, \$ billion

\begin{tabular}{|c|c|c|c|c|}
\hline & Total Debt & Governmental & Corporate & Reserves \\
\hline 1998 & 182,9 & 149,9 & 33,0 & 17,7 \\
\hline 2013 & 703,9 & 85,5 & 618,4 & 537,6 \\
\hline
\end{tabular}

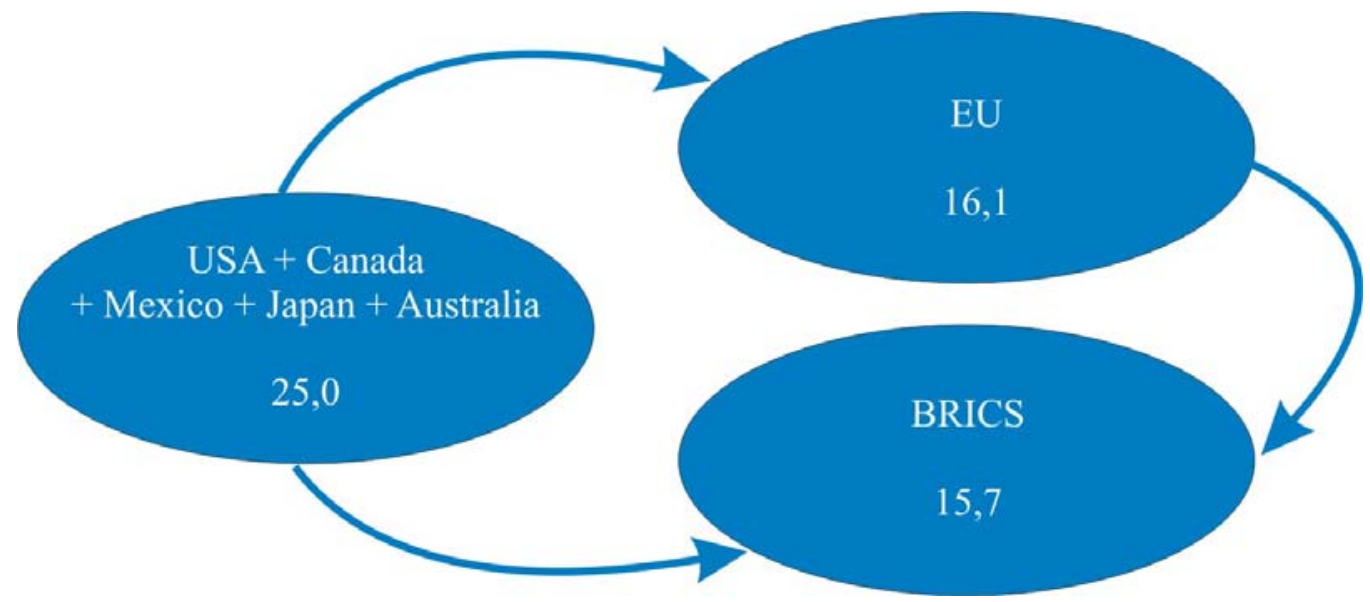

Figure 6. World Economy Scores 
countries. During 2000-2013 all-Russia export to the NEA increased almost 14 times and the export from the Russian Far East 10 times. The share of foreign direct investment allocated in the Far East of Russia decreased to $50 \%$ as to 2013 in spite of the Sakhalin offshore oil and gas' extraction and export. But up to date the Russian Far East remains one of the most important «brick» in the Russian cooperation strategy in NEA.

Since 2003 Russia began to accelerate the investment dynamic in the Far East (figure 7) and main targets of these investments were the developing of transit infrastructure, the national prestige on Pacific and including into export new natural resources. Investment growth rate in the region up to date is higher than national average indicator.

Of course main economic effect in the Far East can be describe as: «high investment's growth - high export growth - modest GDP growth» because export sector is the most effective field of production factors using and foreign market as well as in 1990s remains the most important factor of regional economic dynamic. Figures 8-9 illustrated this effect. Mainly due to this effect the Fareastern regional export value is up to date around $27 \%$ of all Russian export to the NEA in spite of Siberian regions expansion.

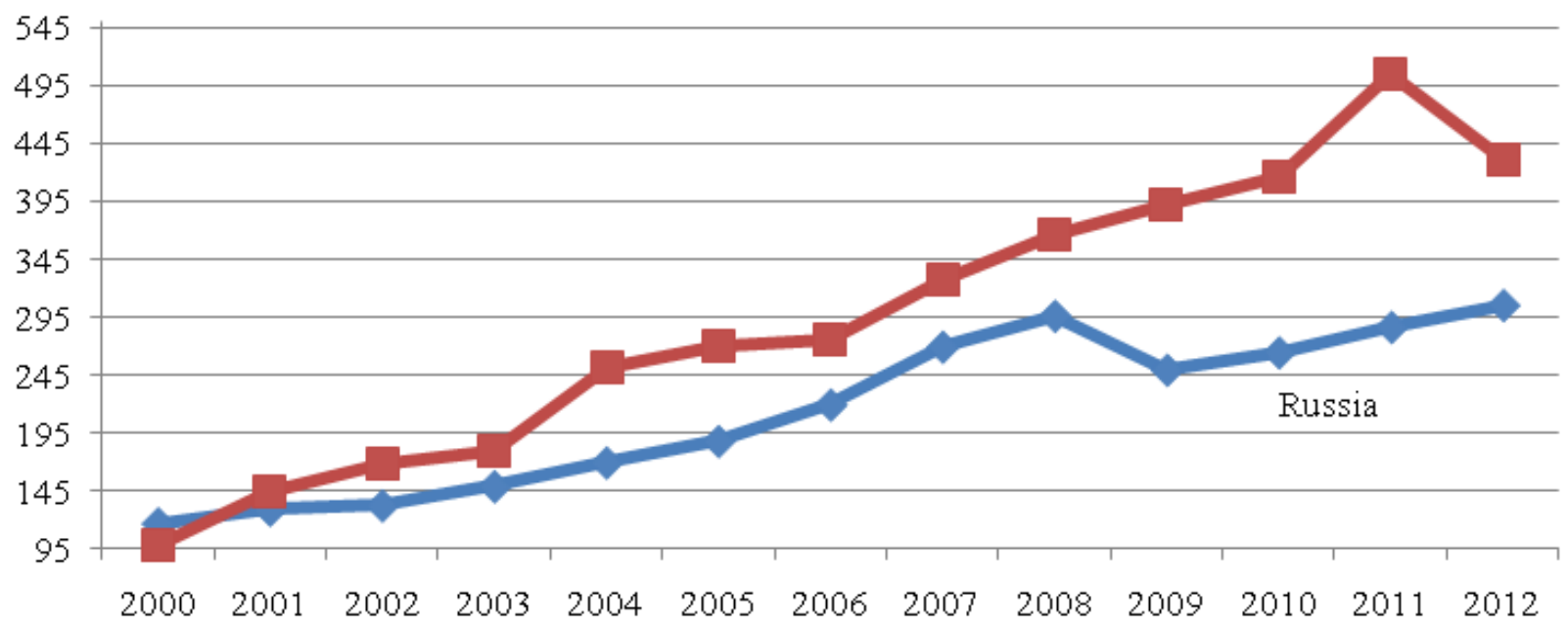

Figure 7. Fixed Capital Investments, Russian Far East, $2000=100 \%$

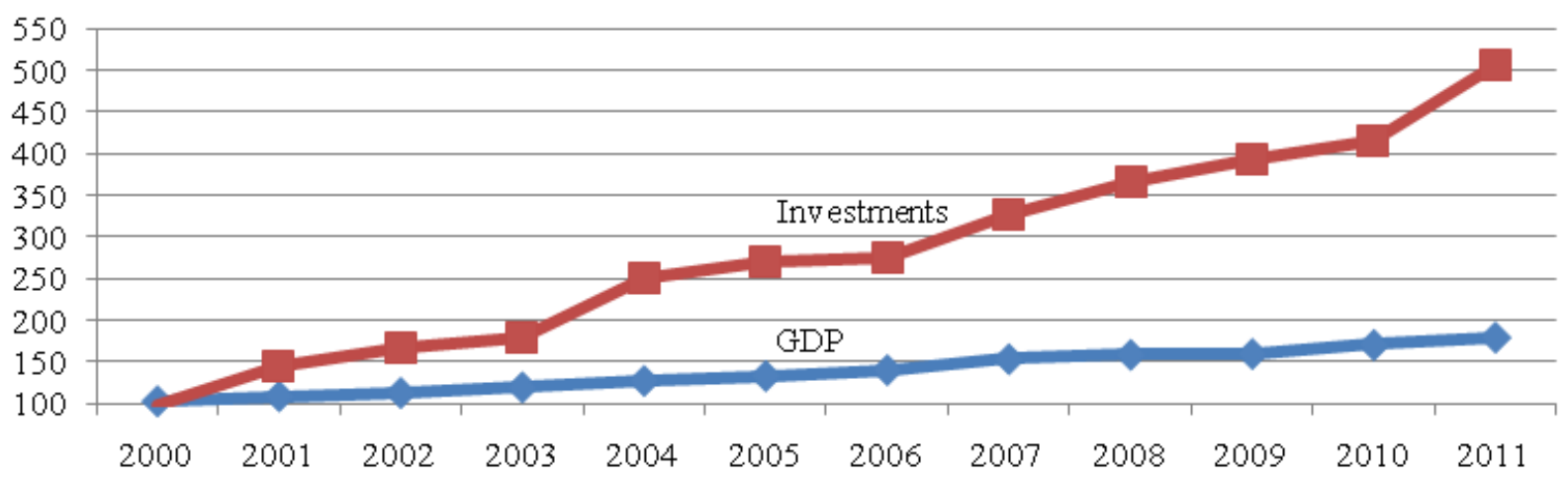

Figure 8. Foreign Trade and Investments dynamic, RFE, \% 


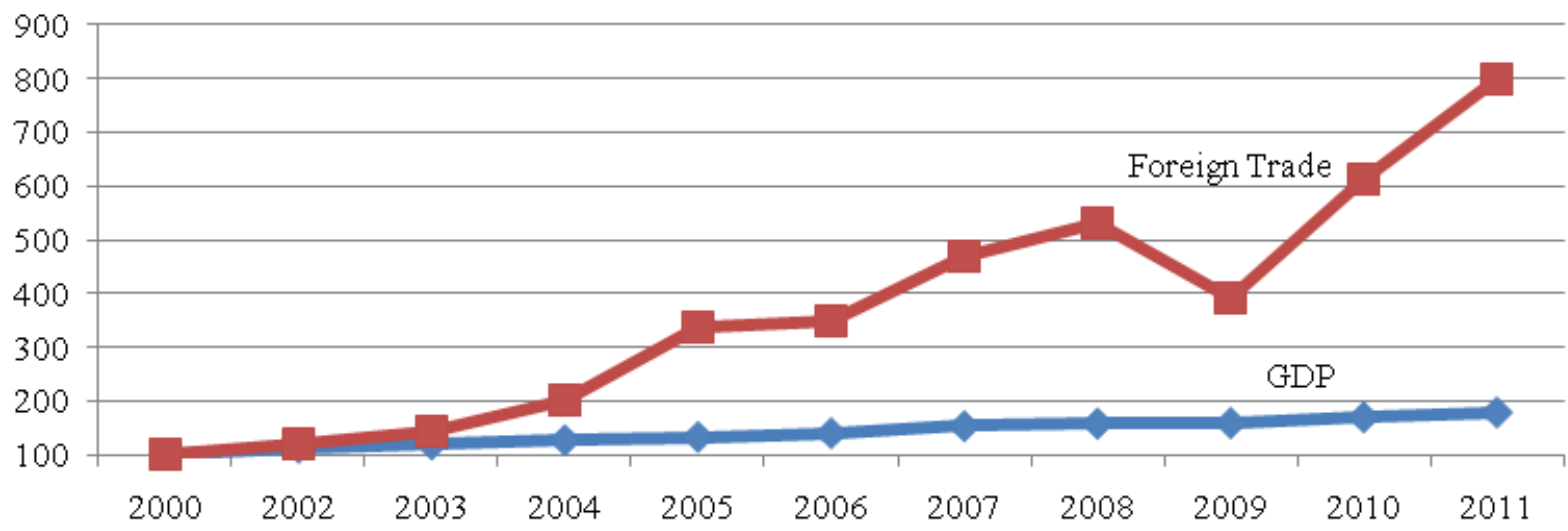

Figure 9. Foreign Trade and GDP Dynamic, \%

The increasing of the regional trade as well as above mentioned effect' appearing dated by 2004 due to beginning of the Sakhalin project operation. And main part of the regional export consists from fuel goods (figure 10).

In case of Japan and ROK the share of oil and gas export is much higher (figure 11), but the regional export to China is more diverse (figure 12) reflecting more deep and mutual economic ties. In future the share of energy export to China can be increased due to confirmed recently projects of constructing new gas pipeline from Eastern Siberia and Yakut Republic. At the same time additional volume of machinery goods and engineering

Import

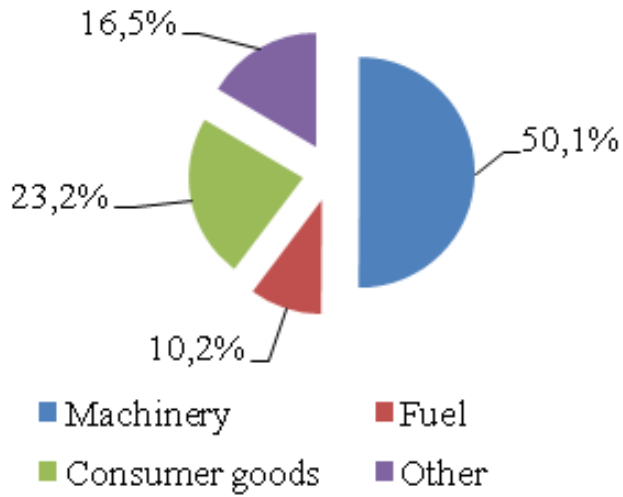

services can be appeared after the beginning of the joint projects in field of aerospace industry.

By the way the trade dependence' increasing of the Russian Far East on the NEA which was a save for the regional economy and up to date and for midtime perspective remains the fundamental factor of market stability can transformed into a problem in long period because of creating a monopsonic trade model for the Russian Far East. While the intraregional trade of China, Japan and ROK during 2000-2012 was stable (17-18\%) because of diversification of their geographical structures, the dependence of the RFE on trade with NEA was increasing from $56 \%$ to

Export

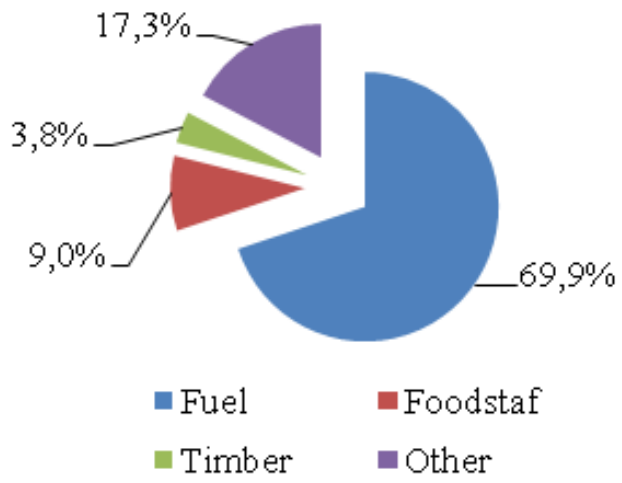

Figure 10. Russian Far East Foreign Trade, commodity structure, 2012, \% 
Japan

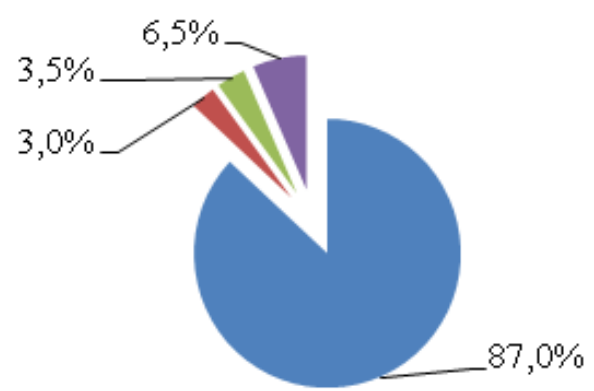

- Oil and gas $\|$ Coal $=$ Machinery $=$ Others
ROK

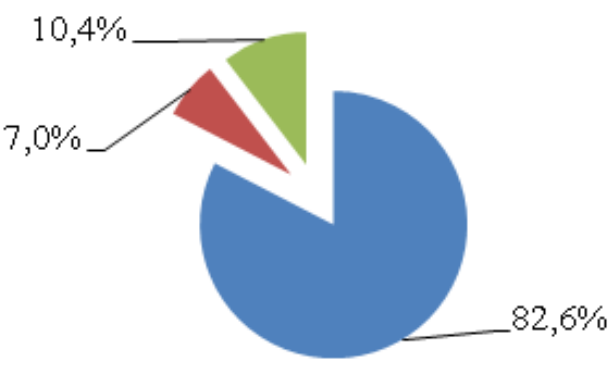

- Oil and gas $\quad$ Fish $\quad$ Others

Figure 11. Commodity structure of the FE export to Japan \& ROK, 2012, \%

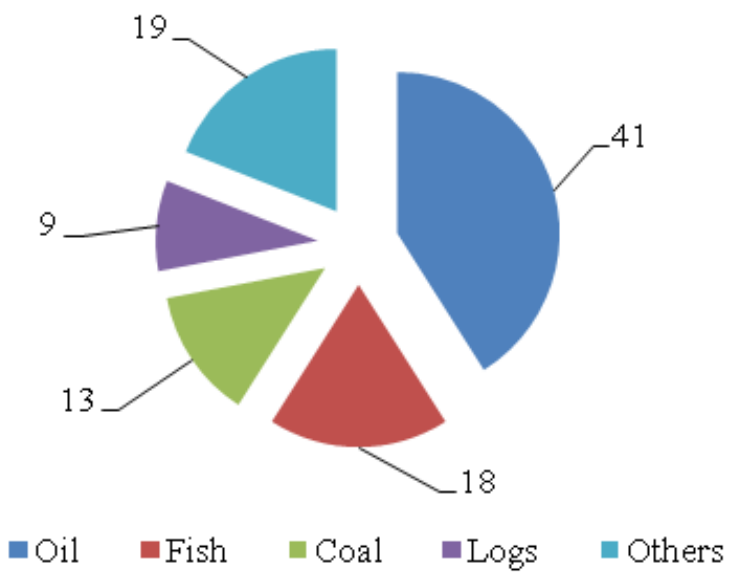

Figure 12. Commodity structure of the FE export to China, 2012, \%

$80 \%$ (table 3). It means that the regional economy stability bases only on market stability of the «NEA Big Triangle» and one of the important tasks for the region is to look for new trade partners.

For the Far East a dependence on foreign investments is much more important that for the Russian economy as a whole. For 2012-2013 average annual volume of fixed capital investment in the Fareasterm economy estimates as \$20-22 billions and the volume of total foreign investments reached $\$ 9$ billion in average. The volume of foreign direct investments in same period can be estimated as
$\$ 2,5$ billion. It means that share of total foreign investments for this period was more than $40 \%$ (10-12\% for all Russia). In case of direct investments the share of foreign investments was around $10 \%$ against $2 \%$ for all Russia [4]. Foreign investments are playing critical role mainly for the export oriented regional sectors such as oil and gas, diamonds, timber, financial services $(90 \%$ of all investments). By the way NEA countries are not sufficient investors to the Far East (exclusion is Japan). Main investors to the regional economy are Cyprus, Netherland, USA, and Great Britain. 
Table 3

Intraregional Trade: NEA

\begin{tabular}{|l|c|c|c|c|}
\hline \multirow{2}{*}{} & \multicolumn{2}{|c|}{2000} & \multicolumn{2}{c|}{2012} \\
\cline { 2 - 5 } & Total, \$ billion & With NEAC, \% & Total, \$ billion & With NEAC, \% \\
\hline China & 530,2 & 22,2 & 4260,0 & 14,5 \\
\hline Japan & 988,6 & 13,8 & 1926,9 & 22,6 \\
\hline ROK & 402,6 & 20,7 & 1283,6 & 24,9 \\
\hline RFE & 4,6 & 56,4 & 36,4 & 78,9 \\
\hline
\end{tabular}

\section{Can Russia Benefit from the NEA Cooperation' Acceleration?}

There are three main directions for it. First, increasing of investment flows for the Far East and Eastern Siberia development as well as getting comparatively stable and dynamic market for natural resources extracting now and in future there. Second, receiving an alternative source of financial and technological resources. Third, obtaining additional scale market for national extracting sector and long budget incomes stabilization.

All three results can be reached only in case of radical changing of Russian economic model and political paradigm [2].

Modern economic model in Russia was created as a reaction on the 1998 financial crisis followed by ruble devaluation, oil prices growth and import substitution development. Increasing of world oil prices which provoked the growth of real consumer consumption (250\% as of 2000-2010) led to the growth of domestic consumer goods supply. But this effect was almost disappeared till next crisis (2009-2010). Though oil prices and export revenues remained enough high (figure 13), after 2008 their growth was very modest and could not be recovered $[1 ; 4]$.

At the same time domestic inflation was going on (figure 14) and ruble became overvalued (figure 15).

Raising of production costs because of high inflation and decreasing of gross revenues due to overvaluing of ruble led to

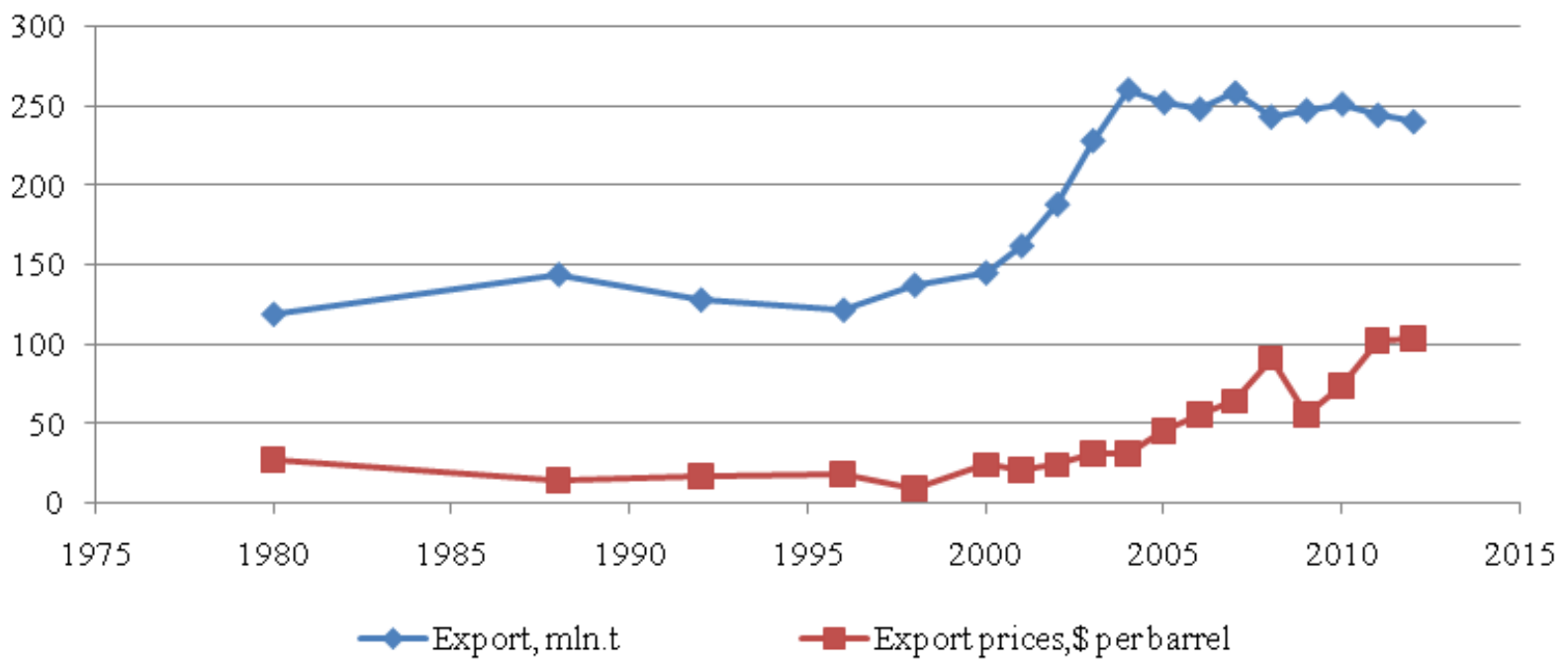

Figure 13. Russian oil export 


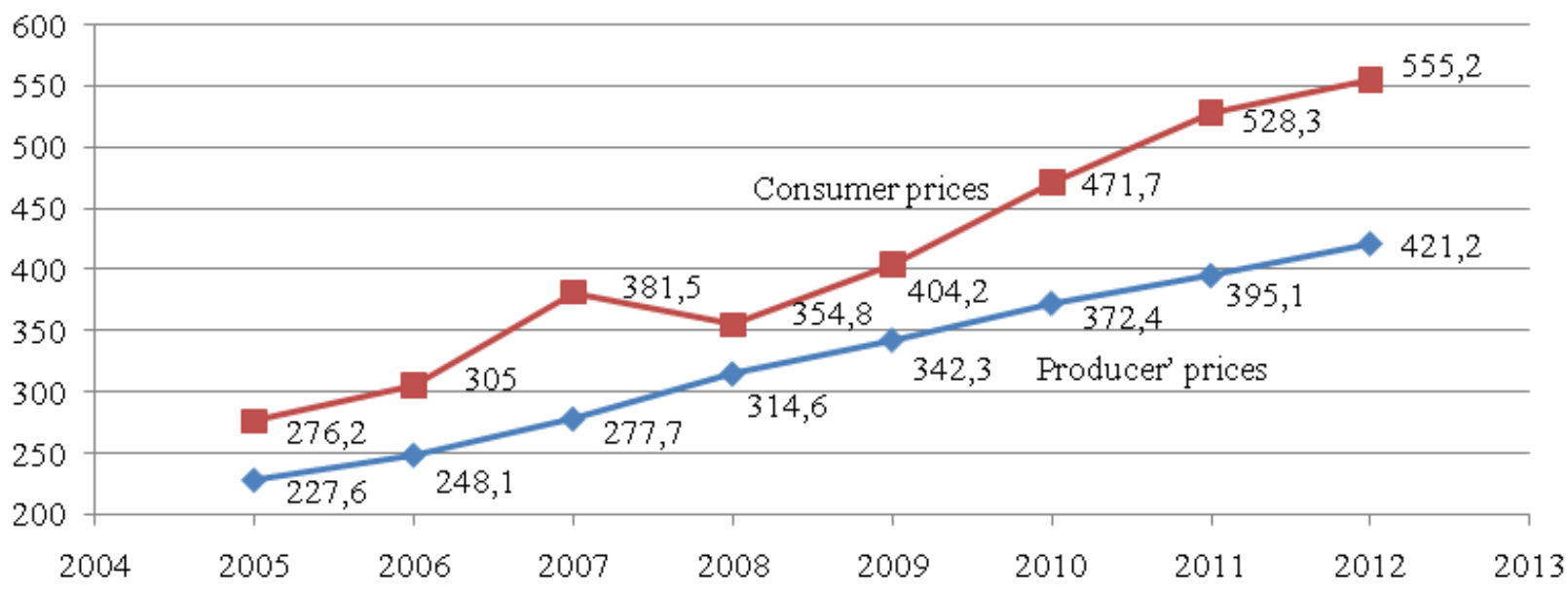

Figure 14. Retail and Wholesale Price Indexes

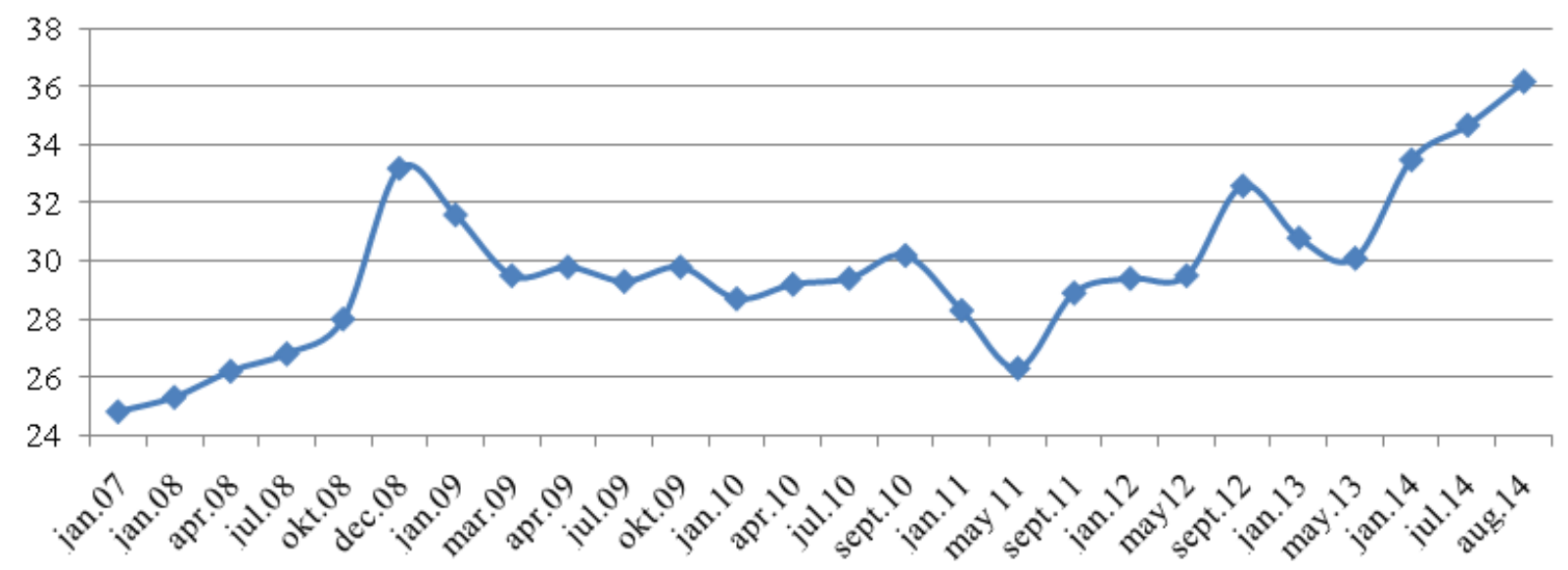

Figure 15. Exchange rate, ruble/US dollar

diminishing of a profitability in Russian industry including oil and gas [2].

Low level of new investment project profitability and fear of speculation in exchange market were reasons of comparatively high domestic interest rate and internal deficit on investment resources. Oil and gas revenues in form of federal budget reserve funds exported to US and EU. Than Russian corporations and banks have borrowed their money in form of long term loans and securities. As a result capital outflow began growing up.

The level of domestic demand supported by two factors: increasing of personal incomes and growing up of governmental consumption including governmental investments. High growth rates of personal incomes in 2000-2007 change by almost stagnation in this sphere except pensions (GDP growth rates in 2009-2012-160\%, pensions $-170 \%$, salary - 139\%). Governmental demand was connected mainly with military spending and investments to the «Exhibition Economy»realization of enormous by scale projects (Olympics game, Universidad, APEC Summit, «Skolkovo», «New Moscow», «Goscorporations» and so on). Such projects are oriented to rising of national prestigious and strengthening of personal leadership but as a rule they are "not followed by rising of do- 
mestic demand, export possibilities, technological modernization, appearing of new types of businesses because of very poor national economic structure and level of qualification. As a result they cannot create the high level of incomes' augmentation now or in future. The most evident effect of such projects - creation of richness and prosperity illusions, first, and high level of corruption in economy.

Such economic policy can be named as «economy of squander». In USSR such economy was created to get «socialism win». In modern Russia scaled spending of public funds has goal to gratify of vainglory of the national governance.

Together with too tall political ambitious dimension of domestic demand' growth technological no competitiveness and poor institutions have stipulated since 2013 not only the economic stagnation but putted under doubt the possibility to use potential earnings from international cooperation as a whole including NEA cooperation. Of course it will be possible in case of the economic model, institutional construction and political imperatives' correction.

\section{Список литературы}

1. Минакир П.А. Новая стратегия развития Дальнего Востока России: проблемы и перспективы // Проблемный анализ и государственно-управленческое проектирование. 2014. № 4 .

2. Минакир П.А. Промышленная политика // Журнал Новой Экономической Ассоциации. 2014. № 2. C. 180-185.

3. Минакир П.А., Горюнов А.П. Восточный вектор государственной экономической политики: новые рынки или «новая стратегия» // Бюджет. 2014. № 2.

4. Прокапало О.М., Исаев А.Г., Суслов Д.В., Мазитова М.Г. Экономическая конъюнктура в Дальневосточном федеральном округе в 2013 г. // Пространственная экономика. 2014.

№ 2. C. 106-140.

\section{References}

1. Minakir P.A. New Development Strategy of Russian Far East: Problems and Prospects. Problemnyy analiz i gosudarstvenno-upravlencheskoe proektirovanie [Problem Analysis and Public Administration Projection]. 2014. No. 4. (In Russian)

2. Minakir P.A. Industrial Policy. Zhurnal Novoy Ekonomicheskoy Assotsiatsii [Journal of the New Economic Association]. 2014. No. 2. Pp. 180-185. (In Russian)

3. Minakir P.A., Goryunov A.P. Eastern Vector of State Economic Policy: New Markets or «New Strategy». Byudzhet [Budget]. 2014. No. 2. (In Russian)

4. Prokapalo O.M., Isaev A.G., Suslov D.V., Mazitova M.G. Economic Situation in the Far Eastern Federal District in 2013. Prostranstvennaya economika [Spatial Economics]. 2014. No. 2. Pp. 106-140. (In Russian)

\section{Для ичитирования:}

Минакир П.А. NEA Economic Integration: Russian Perspectives (Экономическая интеграция в СВА: российские перспективы) // Регионалистика. 2014. Т. 1. № 2. С. 71-81.

For citing:

Minakir P.A. NEA Economic Integration: Russian Perspectives. Regionalistica [Regionalistics]. 2014. Vol. 1. No. 2. Pp. 71-81. 
Представляя читателям «Регионалистики» настоящую рубрику, редколлегия журнала считает своим долгом объяснить, чем она руководствовалась. Мы полагаем, что обращение к истории региональных исследований будет небезынтересно, причём как в познавательном (никогда не помешает знать то, каким образом эволюционировала та или иная научная конструкция), так и в прикладном плане (будьто подходы к организации региональных исследований или механизмы трансфера результатов научных исследований в сферу регулирования региональных экономических процессов и систем).

В качестве первого опыта мы предлагаем на суд читателей материал, который в современных журналах, скорее всего, проходил бы под рубрикой «Хроника научной жизни». Однако этот материал, подготовленный Е.3. Волковым, по мнению редколлегии, даёт не только представление о характере Первой Всероссийской Конференции по районированию, но и о состоянии теории и методологии экономического районирования в начале 20 -х годов прошлого века.

А годы эти были весьма примечательны по целому ряду причин. Во-первых, это было время, когда еще сохранялись традиции научных дискуссий присущих российской науке. И дискуссии эти носили не «филологический» характер, столь близкий сердцу многих современных учёных, готовых уточнять, расширять и ещё углублять самые различные определения и т.д., и т.п. Мы вовсе не против терминологических изысканий, но хотелось бы всё-таки больше дискуссий содержательного характера. Предлагаемый материал как раз и является примером того, что продуктивные научные дискуссии могут иметь место даже на конференциях, имеющих, говоря современным языком, научнопрактический характер.

Во-вторых, работа Е.3. Волкова даёт возможность понять то, как районирование, до тех пор инструмент экономического анализа пространственной неоднородности, становилось элементом системы государственного регулирования экономики. Более того, таким элементом, с которого начинается стратегический анализ развития экономики отдельных экономических регионов (тогда - областей) и национальной экономики в целом. 
ВОЛКОВ

Евгений

Захарович

1883-1942

Экономист, специалист в области экономической статистики; профессор (1932).

Окончил Московский

университет (1914).

В 1918-1920 гг. работал в

Киеве и Харькове в

статистических и

экономических учреждениях.

В 1921-1931 гг. - в Москве

в Госплане СССР,

в 1928-1930 гг. - в

Центральном управлении

народнохозяйственного

учёта СССР.

В 1930 г. была издана под

редакцией и с предисловием

С.Г. Струмилина книга

Волкова «Динамика народонаселения СССР

за 80 лет», которая вошла

в историографию как одно

из первых советских

историко-демографических

исследований.

() Волков Е.3., 2014
УДК $911.6+330.8$

\section{НА ПУТЯХ К ПЛАНОВОМУ ХОЗЯЙСТВУ (ПЕРВАЯ ВСЕРОССИЙСКАЯ КОНФЕРЕНЦИЯ ПО РАЙОНИРОВАНИЮ)}

\section{ON WAYS TO A PLANNED ECONOMY (FIRST ALL-RUSSIAN CONFERENCE ON REGIONALIZATION)}

Первая Всероссийская Конференция местных работников, созванная в Москве по постановлению президиума Госплана Секцией Районирования ${ }^{1}$, носила характер полуофициального подготовительного совещания, имевшего своей целью взаимное ознакомление между собой работников по районированию Госплана и мест, а также выявления наиболее сложных методологических вопросов ${ }^{2}$. Несмотря на такой характер конференции, прения, развернувшиеся на ней, доклады и сообщения, ей представленные, и принятые ею резолюции представляют настолько большой интерес, что на них приходится остановиться с возможной подробностью.

Кроме докладов с мест, содержания которых мы коснёмся ниже, особый интерес к себе вызвали: вступительное

Печатается по: Волков Е.3. На путях к плановому хозяйству (Первая Всероссийская Конференция по районированию) // Народное хозяйство. 1922. Март. С. 40-49. Текст к настоящему изданию, включая комментарии, подготовлен А.Н. Демьяненко и В.Н. Украинским. Сохранены орфография и пунктуация оригинального издания, исправлены только явные опечатки и некоторые сокращения. (Примеч. ред.)

${ }^{1}$ Секция районирования Госплана - структурное подразделение Государственной Плановой Комиссии (Госплан) при Совете Труда и Обороны (СТО). Первый руководитель секции районирования - И.Г. Александров. Госплан РСФСР был создан 22 февраля 1921 г. на базе Комиссии ГОЭЛРО, после образования СССР - Госплан СССР. (Примеч. ред.)

2 Украинский Госплан на приглашение прислать на конференцию своих представителей от участия в ней отказался, ссылаясь на незаконченность ряда своих работ, а также наличия с его стороны серьёзных возражений против постановки методологии районирования в Госплане. Московское ЭКОСО, принципиально возражающее против самой идеи областного строительства РСФСР, прислало своего представителя лишь с информационными делами. Петроградское ЭКОСО и Северо-Западный Обгосплан также официального представительства не дали, и по работам последнего с информационным докладом было лишь персональное выступление проф. Осадчего. 
слово и дополнительный доклад с описанием районов председателя Секции районирования проф. И.Г. Александрова ${ }^{1}$; доклад по методологии экономического районирования проф. Б.Н. Книповича ${ }^{2}$, доклад о работах Административной Комиссии ВЦИК ${ }^{3}$, доклад о методах порайонного изучения грузооборота Н.А. Поплавского; совместный доклад Л.Л. Никитина $^{4}$ и B.M. Смирнова об организации Госплана, плановых комиссий и их взаимоотношений между собой и ЭКОСО ${ }^{5}$, а также совместный доклад представителей Наркомфина, т.т. Свежского и Чирявского, о методах построения местного бюджета. Необходимость проработки нескольких специальных вопросов вызвала выделение конференцией двух комиссий - одной по

\footnotetext{
${ }^{1}$ Александров Иван Гаврилович (1875-1936) - инженер, экономист; сотрудник Комиссии по составлению «Плана ГОЭЛРО», руководитель секции районирования Госплана (1921-1924), действительный член АН СССР, руководил работами по проектированию Днепровского комбината, комплексному освоению гидроэнергетических ресурсов Ангары («Большая Ангара»); внёс значительный вклад в теорию и методологию экономического районирования, сформулировал основные положения концепции территориально-производственного комплексообразования. (Примеч. ред.)

${ }^{2}$ Книпович Борис Николаевич (1890-1924) - экономист, географ; с 1917 г. сотрудник Народного комиссариата земледелия (НКЗ) и секции районирования Госплана, преподаватель ряда вузов Москвы; автор первых монографических исследований, посвящённых методологии экономического районирования. (Примеч. ред.)
}

${ }^{3}$ Административная Комиссия ВЦИК была организована Всероссийским Центральным Исполнительным Комитетом (ВЦИК) для разработки и проведения реформы административно-территориального деления страны. На местах были созданы республиканские и губернские административные комиссии (Примеч. ред.)

${ }^{4}$ Никитин Леонид Леонидович (1884-1947) - доктор географических наук; в 1920 г. принимал активное участие в работах ГОЭЛРО; в Госплане (секция районирования) и в Комиссии ВЦИК по районированию участвовал в разработке реформы административно-территориального деления страны. (Примеч. ред.)

5 ЭКОСО - экономические совещания или советы; являлись местными органами СТО. (Примеч. ред.) вопросам внутреннего районирования Центрально-промышленной области, другой - по вопросам организации и определения границ Кавказской области. Из этих комиссий до окончания конференции работала и закончила свои работы лишь вторая - Кавказская, что же касается комиссии по вопросам внутреннего районирования Центрально-промышленной области, не успевшей собраться до окончания конференции, то её работу несколько позднее проделало совещание представителей губернских административных комиссий области с участием Секции районирования, под председательством зав. НКВД, тов. Белобородова.

В своём вступительном слове проф. И.Г. Александров подробно остановился на историческом развитии работ секции районирования и её взаимоотношении с административной комиссией ВЦИК. Характеризуя выявленное в этих работах содержание самого понятия "район», проф. И.Г. Александров формулировал его так: «Мы считаем в высшей степени важным, чтобы район был не только удобным местом для сношений, не только удобным административным объединением, но очень активной организацией в смысле правильной постановки народнохозяйственной жизни... Как бы ни относиться к тому или другому методу районирования, во всяком случае надо признать, что вопросы, возникающие в связи с районированием, естественно становятся во главу строительства государства, особенно в то время, когда страна переживает такой глубокий экономический и социальный катаклизм». Сославшись далее на исторический пример Франции, в которой её административное деление на департаменты во время Великой Революции было так же, как и у нас теперь, связано теснейшим образом с глубокими изменениями в строе народного хозяйства, проф. И.Г. Александров указал на аналогичность нашего метода районного подразделения с французским, который, за отсутствием современ- 
ных путей сообщения, также сделал своей базой «экономические артерии страны»бассейны рек. Представив затем подробную хозяйственную характеристику всех районов Европейской а Азиатской России, утверждённых комиссией ВЦИК, проф. И.Г. Александров отметил «первичный характер» границ указанных им районов, нанесённых на карту временно с сохранением целости уездов, что было необходимо для сохранения возможности использования материалов статистических обследований прежних лет, и характеризовал проделанную Секцией районирования Госплана работу по их изучению такими словами: «Каждый из намеченных районов подвергнут тщательному изучению в специальном, особо для этой цели созданном, районном бюро. Кроме того секция пользовалась я местными силами. Так, было при помощи их проделано по Центральнопромышленной области изучение Иваново-Вознесенского подрайона; идёт изучение Северо-Западного района, осуществляемое при помощи петроградских товарищей. При каждом приезде в Москву местных деятелей Секция стремилась извлечь от них максимум информации и проверить свою районную схему. Секция состояла всё время и продолжает состоять в тесной научной связи с Саратовским университетом, со всеми научными институтами Петрограда и Москвы, деятелями Урала, Туркестана и Сибири. В Секции был заслушан ряд докладов представителей Крымской, Белорусской и др. республик. Кроме того, районная схема проверялась в ряде комиссариатов - $\mathrm{HKПC}^{1}$, $\mathrm{BCHX}^{2}, \mathrm{HK}^{3}$ и др., и в некоторых она

\footnotetext{
${ }^{1}$ НКПС - Народный комиссариат путей сообщения. (Примеч. ред.)

${ }^{2} \mathrm{BCHX}$ - Высший совет народного хозяйства при Совете народных комиссаров (СНК) был учреждён 5 (18) декабря 1917 г.; был наделён полномочиями выработки общих норм и планов регулирования экономики, координации деятельности центральных и местных регулирующих органов, народных комиссариатов, Всероссийского совета рабочего контроля и профсоюзов рабочих. После принятия
}

встречала полное согласие. Несмотря на это, Секция считает свою работу ещё долго не законченной, она ищет возможностей установления теснейшей и длительной связи с представителями всех районов для обсуждения и изучения вместе с ними вопросов не только районирования, но и общего плана развёртывания народного хозяйства каждого района как государственного, так и местного. Именно для установления этих связей, а также обсуждения указанных вопросов, Госпланом и созвана по инициативе Секции районирования настоящая конференция».

По предложению тов. Кильчинского конференция заслушивает информации местных работников о постановке вопросов районирования на местах. Из докладов выясняется, что отсутствие на местах точной информации о характере работ Секции районирования Госплана во многих случаях привело к ряду такого рода постановок отдельных вопросов, которые с точки зрения государственных задач районирования являются совершенно нецелесообразными. Предоставленные самим себе места шли разными методами районирования, преимущественно отдавая предпочтение статистико-экономическим и естественноисторическим описаниям. Подход к пониманию и осознанию характера своего района с точки зрения его потенциальных производственных возможностей, с точки зрения перспектив направления его хозяйственной структуры, как правило, оказывался совершенно чужд местам. Многие из работников впервые услышали на конференции о «динамическом методе» райони-

Конституции РСФСР в 1918 г. переименован в Высший совет народного хозяйства РСФСР (ВСНХ РСФСР), которому в августе того же года был придан статус многоотраслевого народного комиссариата. (Примеч. ред.)

НКЗ - Народный комиссариат земледелия РСФСР, образован декретом II Всероссийского съезда Советов 26 октября (8 ноября) 1917 г. Осуществлял управление сельским хозяйством, землеустройством, мелиорацией и лесным хозяйством. (Примеч. ред.) 
рования, принятом Секцией районирования Госплана. Много мешала на местах объективности их работ приверженность местным интересам, необходимость замыкаться в существующие губернские и областные границы, часто совершенно не отвечающие хозяйственным взаимоотношениям края. Много путаницы в этой работе внесло на места появление проекта тов. Ларина $^{1}$ о сокращении числа губерний, но и проект Секции Районирования, поскольку он был известен местам, лишь в немногих случаях был встречен без возражений, сущность которых сводилась к отстаиванию местами идеи законченной замкнутости своих территорий в хозяйственном отношении, или более широких территориально хозяйственных интересов - интересов областей и самого государства. Отвечая на все эти возражения, проф. И.Г. Александров ограничился следующими разъяснениями:

«Недоброжелательные отношения к областному делению ряда Губисполкомов ${ }^{2}$ (Москва, Смоленск, Витебск, Кубань, Кавказские Республики) объясняется старыми «областническими» тенденциями, ставившими своей целью стягивание области к одному центру для командования. Ни у Госплана, ни в административной комиссии ВЦИК, ни в комиссии ВЦИК тов. Калинина ${ }^{3}$ такого рода тенденций нет, ибо все эти комиссии стоят на точке зрения возможно широкой самодеятельности мест

\footnotetext{
1 Ларин Юрий (Лурье Михаил Залманович) (1882-1932) - профессиональный революционер, экономист; после 1917 г. принимал участие в организации ВСНХ и Госплана; был членом СТО и ЦИК СССР; автор работ по вопросам социалистической экономики. (Примеч. ред.)

${ }^{2}$ Губисполком - губернский исполнительный комитет. (Примеч. ред.)

${ }^{3}$ Комиссия ВЦИК тов. Калинина - комиссия при Президиуме ВЦИК под руководством М.И. Калинина (председателя ВЦИК) была организована в 1922 г. для рассмотрения предложений Госплана по проведению реформирования административнотерриториального деления страны на принципах экономического районирования. (Примеч. ред.)
}

и не имеют ни малейших намерений подчинять губернии всецело областным органам. Определённо выявляется необходимость выработать единый подход к районированию, единый метод разделения на районы, который позволил бы провести всю работу по районированию РСФСР, как единое целое... Что касается районов Госплана, то эти районы строятся, как перспективно-производственные. В основу их построения клались и естественноисторические и статистико-экономические производственные и целый ряд других признаков; однако, статистика при этом учитывалась лишь в динамическом смысле, в силу невозможности непосредственного пользования её данными за прошлые годы из-за крушения всех тех взаимоотношений, которые их для своего времени определяли, и особенности её современных цифр, характеризующих лишь преходящее, патологическое, состояние данного момента».

Затем конференцией были заслушаны доклады Б.Н. Книповича и К.Д. Егорова по методам районирования, в связи районирования экономического с административным. В тезисах Книповича мало отразилась самая сущность того метода, который Секцией районирования выдвигается в противовес статистико-экономическому, под именем метода интегральнопроизводственного, динамического, и с этой стороны отчасти оказался прав М.Ф. Заменгоф, указавший, что доклад Б.Н. Книповича, пытавшегося в своих тезисах дать какой-то компромисс между методологической позицией Секции районирования и традиционным статистикоэкономическим подходом к идее районирования, привычным работникам ЦСУ ${ }^{4},-$

\footnotetext{
${ }^{4}$ ЦСУ (Центральное Статистическое Управление) образовано 25 июля 1918 г. при СНК РСФСР. В его функции входили ведение статистики всех отраслей народного хозяйства, производство, обработка и публикация материалов переписей. В 1918 1923 гг. на местах были созданы губернские, уездные и городские статистические бюро при испол-
} 
по существу ничего нового не дал. В своём докладе Б.Н. Книпович не коснулся методологического объяснения его районов, их методологического обследования и оправдания. А между тем конференцию наиболее сильно интересовали именно эти последние вопросы, так как многое в характеристике и границах этих районов им казалось чрезвычайно спорным. Именно на этих позициях противниками метода Секции районирования Госплана был дан ей на конференции решительный бой.

Наиболее резко заострил свои возражения М.Ф. Заменгоф, восставший вообще против экономического районирования. Его тезис - «какие могут существовать экономические районы, когда у нас всё хозяйство натуральное», подкреплённый весьма рискованным соображением, что «такие районы в общем организме народного хозяйства будут играть роль не необходимых маховых колес, а других вращающихся, тех, которые в народе принято называть ветряными мельницами», был поддержан, в конце-концов, лишь одним из участников конференции - кубанским статистиком Коломенским, приверженцем хозяйственного уклада России прошлого, дореволюционного периода. Выступления Заменгофа и Коломенского не содействовали успеху противников интегральнопроизводственного, динамического метода Госплана и жестоко были отпарированы в разъяснениях, данных конференции работниками Секции Районирования. В конечном счёте конференция подавляющим большинством голосов фиксировала своё вполне благожелательное отношение к идее экономического районирования России, что и выразилось в единогласном одобрении её пленумом внесённой на утверждение специальной комиссией его резолюции по докладам И.Г. Александрова, Б.Н. Книповича и К.Д. Егорова. Эта резолюция в таких тезисах определяет отноше-

комах Советов. В 1923 г. был образован общесоюзный статистический орган. (Примеч. ред.) ние конференции к направлению дальнейших работ по районированию, как в самом Госплане, так и в местных плановых комиссиях.

1. При районировании надо иметь в виду интересы будущего развития страны, в связи с чем необходимо, при установлении районов, учесть методы техники в области производства и транспорта. 2. Таким образом, план развития производственных сил района является основной формой определения его задач и той территории, которую он должен охватить. 3. Районы при этом образуют комбинированные хозяйства с определённой специализацией в сторону естественных ресурсов района и навыков населения. 4. Районы базируются на крупных производственных центрах. 5. Экономическое районирование должно служить исходным моментом для будущего административно-хозяйственного разделения страны. 6. Основой работ по районированию и их завершением является установление районных производственных балансов и баланса Республики с учётом внешнего обмена. 7. При работах по районированию необходимо точно учесть как те соотношения, которые имели место в довоенное время, так, особенно, и те изменения их, которые происходили в стране в связи с мировой войной и революцией. 8. Во всей этой работе необходимо участие местных работников, их сплочённое сотрудничество с центром, причём, поскольку в деле построения крупных областных центров инициатива естественно остаётся за центром, постольку внутреннее районирование должно быть делом мест. 9. В основу деления Республики на районы кладётся тройное членение: область, округ, волость. 10. В основу работ по статистикоэкономическому районированию необходимо положить тезисы Б.Н. Книповича с вовлечением в работы материалов транспортной статистики для проверки целесообразности намеченных районов и экономических областных центров и для разработки вопросов, связанных с внутренним 
районированием. При этом существенно важным является использование статистических материалов последних лет. - Настоящая резолюция утверждена в вечернем заседании Пленума Конференции 26/II 1922 г.

Тезисы доклада К.Д. Егорова, вызвавшие не менее горячие прения, чем и доклады Б.Н. Книповича и И.Г. Александрова, кратко сводились к следующему: 1. Основным пробелом в области советского строительства по настоящее время является неприкосновенность старого административного разделения Республики на губернии, уезды и волости, сковывающее хозяйственное развитие страны. 2. Революция разрушила до основания старый строй и требует новых организационных форм от самого мелкого населённого пункта вплоть до Кремля. 3. Опыт показал, что к территориальному вопросу необходимо подходить извнутри тех организационно-хозяйственных проблем, постановку которых повелительно диктует жизнь трудового фронта. 4. Немыслимо небывалые в истории задачи советского строительства уложить в «старые мехи» - в старое административно-полицейское разделение территории Р.С.Ф.С.Р. на губернии, уезды и волости, лишённые прав хозяйственной инициативы. 5. В нашей стране, с её чрезвычайным разнообразием естественных условий, способов приложения народного труда и систем народного хозяйства, уже давно возникла практическая необходимость подразделить всю её огромную территорию на отдельные районы, которые можно было бы рассматривать, как нечто однородное по своим культурноэкономическим особенностям. В периоде революционной ломки 1917-19 лет эта необходимость вызвала к жизни стихийное движение широких трудовых масс к переустройству своих старых территориальных границ, не отвечавших уже давно условиям их хозяйственного быта и тенденциям его развития. В 1918 году Советская власть декретирует права мест практически при- менять принцип экономического тяготения при организации волостных районов вокруг своих естественных хозяйственных центров. Отсюда начало связи экономического районирования с административным. Эта связь - продукт революционного творчества самих трудовых масс. Эта связь - завоевание Октябрьской Революции.

6. Ломка старых волостных границ влечёт за собой ломку уездных и даже губернских разграничений. Принцип экономической целесообразности меняет и здесь самый дух старой административной полицейской системы. Кустарничеству, стихийно-непродуманному творчеству в этом направлении отдельных мест кладёт предел образование президиумом ВЦИК 6-го февраля 1920 г. Центральной Административной Комиссии ВЦИК и её местных органов. Все результаты продолжительных совместных трудов Административной Комиссии ВЦИК и Секция Районирования Госплана утверждены президиумом ВЦИК. В связи с этим К.Д. Егоров полагает, что новое административное деление территории Р.С.Ф.С.Р. надлежит производить на основе тех основных положений, которые были приняты Административной Комиссией ВЦИК ещё в 1920 г. и утверждены VIII Всероссийским Съездом Советов. В основу его должны быть положены следующие признаки: а) сосредоточение промышленности, б) сосредоточение технических культур, в) тяготение населения к промышленно-распределительным (торговым) пунктам - мелкорайонное деление, г) направление и характер путей сообщений - железнодорожных, водных, шоссейных и других, д) численность населения, е) национальный состав населения. К этим признакам, в результате связи с работами Секции районирования Госплана, присоединились: ё) естественно-исторические условия: ж) распространённость естественных ресурсов, з) профессиональные навыки населения, и) тяготение населения к производственным пунктам, к) границы распределения местного сырья и л) основ- 
ные тенденции местного грузооборота.

7. Остаются в силе основные тезисы Административной Комиссии: а) «основным ядром» новых районов (областей, округов, районных волостей) должны быть пролетарские центры; окружающая их территория должна обеспечить нормальное развитие главнейших отраслей промышленности данного района; б) при установлении границ национальных образований момент экономического тяготения также должен быть учтён.

8. При новом административноэкономическом делении Р.С.Ф.С.Р. должен быть взят твёрдый курс на сокращение разростания числа административных единиц. Период Временного Правительства, так называемой «власти на местах», и эпоха военного коммунизма довели число этих единиц до колоссальной цифры 15064 волостей, 701 уездов и 93-х губерний и областей, в то время, как в дореволюционное время во всей Российской Империи в старых границах число волостных единиц не превышало 8-9 тысяч. Однако, подход к делу сокращения волостей должен быть самый осторожный и ни в коем случае не итти в разрез с осознанными и местными хозяйственными нуждами. Сокращение волостных единиц, по примеру Псковского и Владимирского мелкого районирования, должно итти за счёт их порайонного объединения в мелкую советскую единицу на основе учёта всех как статистических, так и динамических признаков, определяющих строй их хозяйства и возможное его развитие. Тем же путём должно продвигаться и образование из уездов административно-экономических округов, границы которых могут во многих случаях не совпадать с границами уездов, как могут не совпадать границы областей с границами уничтожаемых губерний, а проходить по разделу экономических тяготений к соседним окружным центрам районных волостей.

Совместный доклад т. Л.Л. Никитина и В.И. Смирнова по вопросам организации
Госплана, местных плановых комиссий, их взаимоотношений между собой и с ЭКО$\mathrm{CO}$ носил характер информации по проекту новой организации этих учреждений, который как раз в то время обсуждался в Госплане. Этот проект ныне, вызвав полное одобрение конференции, уже одобрен президиумом Госплана 7-го и 12-го марта 1922 г. и утверждён для внесения на окончательную санкцию в $\mathrm{CTO}^{1}$. Что же касается резолюции конференции по существу самого проекта, то она нашла следующее:

«На основе заслушанных докладов В.И. Смирнова и Л.Л. Никитина, конференция постановляет: І. Признать необходимым скорейшую организацию областных ЭКОСО и областных Плановых Комиссий${ }^{2}$ ). II. Признать, что основной задачей Плановых Комиссий является: а) разработка общего плана хозяйства области в связи с общегосударственным планом её развития; б) проблема организации местного бюджета; в) регулирование местной экономической жизни; г) проведение на местах плана областного районирования; д) выработка методологии внутреннего районирования и е) разработка плана местного хозяйства. III. Признать, что для увязки вопросов внутреннего районирования желателен созыв тесных съездов с участием в них представителей местных научных организаций. Участие последних желательно также и в работах Планкомиссий. IV. Считать необходимым установление связи Административных Комиссий с работами Планкомиссий путём постоянного взаимного представительства и установления общего положения, что изменения административных границ должны

\footnotetext{
${ }^{1}$ СТО - Совет Труда и Обороны был учреждён в апреле 1920 г. на основе реорганизованного Совета Рабочей и Крестьянской Обороны. Существовал до 1937 г.; первоначально на правах комиссии при СНК РСФСР, а с 1923 г. - при СНК СССР. (Примеч. ред.)

2 При этом Плановые Комиссии являются по существу совещательными органами, и им не должны быть присвоены распорядительные функции.
} 
проводиться на основе разработанной Планкомиссией схемы внутреннего экономического районирования».

Совместный доклад представителей Наркомфина Ржевского и Чернявского «О методах построения местного бюджета» обрисовал конференции характер работ по этому вопросу существующего при Наркомфине Института Экономических Исследований ${ }^{1}$ и достигнутые этой работой законодательные результаты. Основным положением, из которого в своей методологии построения местного бюджета исходил указанный Институт, было признание, как принципа, совершенной неправильности подразделения общегосударственного бюджета на государственный и местный, который никогда и ни при каком случае выдержать невозможно, так как все нужды мест, как бы они ни были малы, не безразличны для государства, ибо для государства совершенно не безразлично, распространено ли народное образование в стране, обеспечено ли население медицинской помощью, имеет ли оно необходимые пути сообщения и хотя бы первичную агрономическую помощь. Исходя из этого принципа, Институт Экономических Исследований остановился на точке зрения, что все нужды, как бы они ни казались на первый взгляд местными, должны покрываться в известном минимуме, одинаковом для всей страны, из государственных средств. Местные же средства должны итти на покрытие тех излишков, сверх минимума, которые в данной местности почему-либо необходимы и вполне возможны.

Однако, в вопросе о том, из каких же, собственно, местных средств места могут покрывать свои излишки, Институт Экономических Исследований попал почти в непреодолимо безвыходное положение. Дело в том, что в прошлом самым главным

\footnotetext{
${ }^{1}$ Институт экономических исследований входил в состав Финансово-экономического бюро (ФЭБ) научного подразделения Народного Комиссариата финансов (НКФ). (Примеч. ред.)
}

источником средств для мест было обложение недвижимости, с национализацией же земли и муниципализацией домовладений этот источник средств исчезнет, следующая же, единственная в настоящее время, статья возможного крупного дохода для мест - надбавка к промысловым государственным налогам в размере 8\% последних, которую имеют право взимать места, - сама по себе не может обеспечить местного бюджета от большого и очень большого дефицита, что, конечно, не только ставит предел развитию местных бюджетов, но и принуждает к их всё большему и большему сокращению до последней степени, даже ниже пределов необходимого, ниже самых последних «голодных» норм.

Чтобы смягчить последствия такого положения, НКФ остановился на двух принципах: 1) государственной дотации губернским органам управления известных сумм для покрытия части дефицита и 2) регулирования местных бюджетов путём предоставления права губернским органам управления распоряжаться всеми средствами губернии, с правом переброски из более богатых по своим поступлениям уездов необходимых средств в уезды более бедные. Организация областных хозяйств придаёт ещё более хозяйственный характер этому регулированию, когда бюджеты определённого количества губерний будут объединяться общим областным управлением ими и когда сокращение количества внутренних административных подразделений в самих областях даст возможность большей концентрации местных средств, чем та, которая имеет место сейчас. Заслушав доклад, конференция выражает пожелание, чтобы, в связи с постановкой проблемы районирования, проектом новой административной системы Р.С.Ф.С.Р. и недостаточной разработкой вопросов местного бюджета, в Госплане в ближайшее время было бы поставлено исследование данного вопроса.

С большим интересом был прослу- 
шан конференцией доклад проф. Поплавского о методах порайонного изучения грузооборота. Профессор Поплавский иллюстрировал этот метод своей работой по изучению грузооборота важнейших пунктов Республики и её районов, производимой им в настоящее время по заданию Госплана. Согласно его методу, вся система разработки материалов транспортной статистики им разделяется на учёт количества, времени и пространства, а центр тяжести изучения переносится с вопросов эксплоатационного порядка (таковым до сего времени исключительно служила транспортная статистика) на вопросы оценки экономического значения её данных. Отвечая на вопрос о том, в какой связи находится транспортная статистика с районированием, докладчик указывает на связь с транспортным балансом вопросов учёта и выяснения значения не только экономической связи районов между собой, но и отдельных территорий и пунктов внутри районов, позволяя в своём анализе этих моментов спуститься до самых мельчайших территориальных единиц. Заслушав доклад, конференция признала чрезвычайно существенной разработку данных грузооборота по районам в указанных проф. Поплавским направлениях и приветствовала ту реформу транспортной статистики, которую в связи с работами докладчика предпринял НКПС.

Последний, пятый день конференции был посвящён заседанию по детальному обсуждению основных положений всех заслушанных докладов и утверждению резолюций по ним, выработанных в особой комиссии, выделенной для их окончательного редактирования конференцией. В связи с обсуждением этих вопросов возобновился с новой силой спор о методологии. В противовес производственному признаку районирования, выдвинутому Секцией районирования, проф. Яснопольский выступил с защитой признака хлеботорговых тяготений, причём в формулировке тов. Галицкого получается противопоставление обоим методам - и проф. Яснопольского и проф. Александрова, как методам политико-экономического районирования, - методов Б.Н. Книповича, как методов статистико-экономических. Очевидное же различие между подходом к проблеме районирования у И.Г. Александрова и Л.Н. Яснопольского т. Галицкий находит в том, что первый из них, употребляя «проектный метод», строит свои районы на перспективах будущего развития страны, второй же стремится обосновать районы на конкретной жизненной обстановке настоящего дня. Отсюда у них разный подход к учёту важности вопроса о центрах районов. Для Госплана этот вопрос не имеет большого значения, для Яснопольского он, наоборот, крайне важен. По существу же все эти точки зрения и все эти методы сводимы. Работа может производиться одним методом, методом Госплана, а проверяться методами и Книповича и Яснопольского и Поплавского, но при всех условиях она должна быть передана на места.

В заключение проф. Александров ещё раз формулирует позицию Госплана в этом вопросе и даёт такую всех примиряющую его постановку: «Мы подходили к этому вопросу так: Революция должна дать не только разрушение старого, но и дальнейшее новое развитие. Далее, что кладётся в основу этого развития - наше сельское хозяйство или же совершенно новое построение всего народного хозяйства? - Для нас нужен подъём страны именно производственный. И потому в основу наших работ мы положим техникоэкономический метод (выше он был назван производственно-динамическим, политико-экономическим). Мы творим новую жизнь, а не восстановляем старую. Границами районов и переменой центров мы можем пожертвовать. Да, наши районы велики, но пусть они сами дробятся в своём дальнейшем развитии».

«Тезисы Б.Н. Книповича - это только поверка. Мы конечно идём наперекор ста- 
рым мнениям, и поэтому нам нужна большая поверка. Далее, конкретно, по вопросу о центрах, затронутых Л.Н. Яснопольским, я утверждаю, что центр производства Юго-Западного района есть Киев, а не Одесса, которая является научным, торговым, но не производственным центром. Екатеринослав ${ }^{1}$ тоже не может быть центром района в будущем, ибо в результате шлюзования Днепра, он неминуемо должен будет остановиться в своём росте. Что касается Владикавказа, то у него нет производства, но у него все данные к его развитию. В его окрестностях находятся большие залежи руд и других полезных ископаемых. С проведением кавказской магистрали он станет важным железнодорожным узлом, и он необходимо разовьётся в крупный промышленный центр. Таково наше ожидание, но возможно, что мы и ошибёмся».

«Далее, что нам нужно от мест, и что местам нужно от нас? Нужна крупная область, чтобы места могли самостоятельно и живо работать. Масштаб России вообе более крупный, чем в других государствах, и русского человека можно задержать лишь на работах крупного масштаба. Впоследствии, как я уже сказал, районы будут дробиться в зависимости от их роста и значения. Кроме всего прочего, для большого числа районов у нас в настоящее время не хватит работников. Что касается путей сообщения, то в основу наших работ мы кладём не только обычные пути транспорта, но и новые его формы, а именно сверхмагистрали. Это вопрос новый, он чрезвычайно важен, его стоит изучить, и мы просим вас работать в этом направлении. По-моему, тезисы мои и Л.Н. Яснопольского не разнятся по существу. Упрёк в том, что у нас нет цифр, необоснован. У нас были проделаны по ряду районов большие статистические работы с точными цифрами и полным учётом старого и происшедших теперь перемен. В частно-

\footnotetext{
${ }^{1}$ Ныне - Днепропетровск. (Примеч. ред.)
}

сти, схема ГОЭЛРО тем и ценна, что мы использовали её именно в период работы, организации. Но, конечно, нужна ещё очень большая работа. Наконец, конкретно, ... мы образуем плановые комиссии и ЭКОСО, и они уже потом разберут сами вопросы о границах, о центрах, дроблении и соединении районов. Итак, вот наше конкретное основание: 1) наши районы лишь первый рабочий подход к делу; 2) центры намечены для того, чтобы начать работу плановых комиссий; 3) они уже совместно с Госпланом окончательно увяжут границы и установят центры. Что касается старой статистики, она должна служить только поверкой, с точным учётом текущих изменений и увязкой их. В таком виде она нам необходима».

Конференция принимает все эти окончательные разъяснения председателя Секции районирования, что выражается ею в принятии приведённой нами раньше её резолюции по трём докладам о районировании, и на этом её занятия заканчиваются.

В заключение считаем необходимым привести полностью резолюции по докладу проф. И.Г. Александрова о районировании России, принятую 20-го февраля сего года Всероссийской статистической конференцией: 1. Признать работу Госплана по районированию весьма важной и необходимой. 2. Районирование в настоящий момент должно строиться не только на материалах прошлого, а и на предвидении будущего, базирующемся на статистическом изучении и на определившихся уже планах мероприятий, долженствующих повлиять на соотношение хозяйственных элементов в ближайшем будущем. 3. Районирование должно строиться сверху от крупных районов к мелким и по построении последних вернуться в порядке исправления к крупным районам. 4. Принимая во внимание, что административноэкономическое районирование России требует методического использования статистических данных в целях строгого фактического освещения со статистической точ- 
ки зрения, статики, динамики и экономики районов, является необходимым систематическое привлечение к работам Центрального Статистического Управления и его местных органов, областных и губернских, согласно плана, выработанного Госпланом и ЦСУ.

\section{Для ичитирования:}

Волков Е.3. На путях к плановому хозяйству (Первая Всероссийская Конференция по районированию) // Регионалистика. 2014. T. 1. № 2. C. 83-93.

For citing:

Volkov E.Z. On Ways to a Planned Economy (First All-Russian Conference on Regionalization). Regionalistica [Regionalistics]. 2014. Vol. 1. No. 2. Pp. 83-93. (In Russian) 


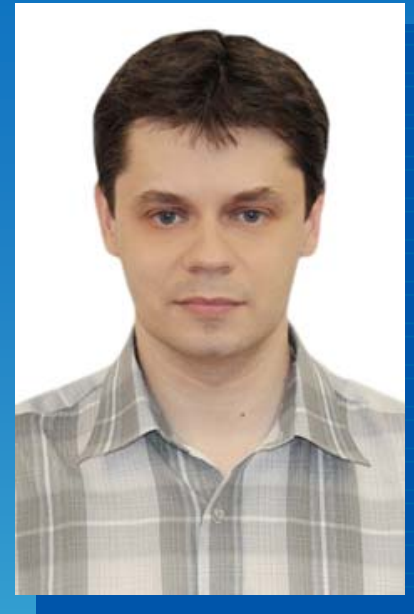

ТКАЧЕНКО

Григорий

Геннадьевич

Кандидат географических наук, старший научный сотрудник

Тихоокеанский институт географии ДВО РАН, ул. Радио, 7 Владивосток, Россия, 690041

TKACHENKO

\section{Grigory}

Gennadyevich

Ph.D. in geography, senior research fellow

Pacific Institute of

Geography FEB RAS,

7, Radio Street,

Vladivostok, Russia, 690041

tkatchenko-gri@mail.ru

(C) Ткаченко Г.Г., 2014

\section{BC}

ВСЕРОССИЙСКАЯ НАУЧНО-ПРАКТИЧЕСКАЯ КОНФЕРЕНЦИЯ «ПРИРОДНО-РЕСУРСНЫЙ ПОТЕНЦИАЛ РЕГИОНАЛЬНОГО РАЗВИТИЯ АЗИАТСКОЙ РОССИИ॥

\section{THE ALL-RUSSIAN SCIENTIFIC-PRACTICAL CONFERENCE «NATURAL RESOURCE POTENTIAL OF REGIONAL DEVELOPMENT OF THE ASIAN RUSSIA»}

24-25 апреля 2014 г. в г. Владивосток состоялась уже ставшая традиционной всероссийская научно-практическая конференция, посвящённая Азиатской России - «Природноресурсный потенциал регионального развития Азиатской России». Инициатором и организатором конференции выступил Тихоокеанский институт географии (ТИГ ДВО РАН), соорганизаторами - Дальневосточный федеральный университет (ДВФУ) и Русское географическое общество (РГО). В работе конференции приняло участие более 80 учёных академических институтов, ВУЗов и других организаций из Владивостока, Хабаровска, Улан-Удэ, Биробиджана, Волгограда, Иркутска, Читы, Чебоксар, Ханты-Мансийска и Ташкента (Республика Узбекистан).

Интерес к Азиатской России сегодня велик, прежде всего, потому, что значение этого региона для страны стремительно возрастает. Азиатская Россия - крупнейшая и одновременно наиболее удалённая от центра страны территория. В то же время регион обладает уникальным географическим и геополитическим положением. Исключительное разнообразие ландшафтов, огромный природно-ресурсный потенциал, тесное соседство со странами АзиатскоТихоокеанского региона и, прежде всего, со странами Северо-Восточной Азии - всё это не только позволяет этому огромному региону играть значительную роль в развитии России, но и делает его одной из самых перспективных и привлекательных территорий мира.

На пленарном и двух секционных заседаниях конференции было заслушано более 40 докладов, охвативших широкий круг актуальных научно-исследовательских проблем в 
изучении Азиатской России: вопросы теории и методологии географических исследований и оценки природно-ресурсного потенциала территорий и акваторий, проблемы изучения природно-ресурсных факторов территориальной организации хозяйства, географические аспекты устойчивого природопользования т.д. ${ }^{1}$

Пленарное заседание открыл директор Тихоокеанского института географии ДВО РАН, академик РАН П.Я. Бакланов, изложивший новый подход к оценке природно-ресурсного потенциала (ПРП) территории и предложил довести его оценку до уровня отдельных целостных геосистем и их природно-ресурсных структур, а не ограничиваться только определёнными территориями или акваториями. При подобном двухуровневом анализе возможна более строгая оценка динамики природных ресурсов. По мнению докладчика, в геосистемах необходимо выделять природноресурсные подсистемы и межресурсные связи и на их основе рассчитывать динамику ПРП геосистемы при различных прогнозных вариантах регионального развития. В процессе дискуссии докладчик отметил, что представление о ПРП геосистемы шире и полнее, чем представление о ПРП территории или акватории. Докладчик выделил четыре составляющих динамики ПРП геосистемы: естественные изменения ресурсных свойств, количественные изменения при добыче, качественноколичественные изменения не осваиваемых природных ресурсов за счёт межресурсных связей и сопряжений, а также за счёт техногенных воздействий на них. Для более полной оценки ПРП геосистемы выступающий предложил использовать балансовые модели, в основе которых лежит уравнение динамики ПРП.

\footnotetext{
${ }^{1}$ По итогам конференции издан сборник материалов: Природно-ресурсный потенциал регионального развития Азиатской России. Владивосток: Тихоокеанский институт географии ДВО РАН, 2014. $358 \mathrm{c}$.
}

В докладе Е.Ж. Гармаева (БИП СО РАН, г. Улан-Удэ) в пространственновременном диапазоне были рассмотрены опасные гидрологические процессы в русле бассейна реки Селенга. Докладчик отметил, что с помощью созданной серии ситуационных карт зон различной степени затопления и трансформации была определена степень опасности процессов и разработаны рекомендации по предотвращению их негативного влияния. Кроме того, докладчик рассмотрел процессы деградации растительности в трансграничном бассейне реки Селенги.

Большой интерес участников конференции вызвал доклад В.П. Каракина (ТИГ ДВО РАН) «К вопросу о ресурсной географии», в котором была отмечена неоднозначность природных ресурсов в развитии территориальных структур различного ранга (что, по мнению докладчика, затрудняет целеполагание в программах регионального развития), а также то, что проблематику природных ресурсов следует рассматривать как приоритетную для российской географии. Оживлённую дискуссию вызвали замечания докладчика о том, что в российской географии и в государственном управлении недооценивается социально-экономико-политическая значимость блока исследований, посвящённых изучению природных ресурсов и природопользования как системного явления. Отвечая на вопросы, докладчик отметил, что современные оценки ПРП территории наиболее часто сводятся к систематизации разнородного материала по различным типам природных ресурсов. Преимущества географического подхода к оценке природных ресурсов объясняются тем, что он базируется на рассмотрении географического пространства как ресурсного и рассмотрении ПРП как свойства этого пространства.

В докладе Ю.А. Авдеева (ТИГ ДВО РАН) «Дальний Восток - драйвер развития России в 21 веке?» было отмечено слабое присутствие России в Азиатско-Тихо- 
океанском регионе, а также выделен ряд наиболее перспективных направлений социально-экономического развития и стратегических ориентиров для Дальнего Востока в АТР: космос, океан и культура. Выход в Мировой океан и формирование в масштабах АТР космического кластера, согласно оценке докладчика, подкрепляются природно-ресурсным и энергетическим потенциалом региона. Доклад вызвал дискуссию среди участников конференции относительно перспектив развития острова Русский и г. Владивосток, в том числе с учётом инфраструктуры ДВФУ. По мнению докладчика, на острове Русский, выступающем в качестве площадки межкультурного взаимодействия стран АТР и России, можно было бы реализовать соответствующий проект, предусматривающий размещение представительств стран АТЭС и ряда российских городов с «узнаваемыми архитектурными силуэтами».

В.Н. Бочарников (ТИГ ДВО РАН) рассмотрел современные константы теории «Человек - общество - природа» в гуманитарной географии. Докладчик обозначил особую роль и место географических исследований в современных условиях, обусловленные многообразием структурных взаимосвязей в территориальных социально-экономических системах: они являются составной частью научного обеспечения инновационной региональной экономики, способствуют совершенствованию мер рационального природопользования, проводятся при разработке и мониторинге исполнения стратегий регионального развития.

М.Т. Романов (ТИГ ДВО РАН), обращаясь к теме развития транспорта, в свете обострения геополитического положения в мире проанализировал перспективы создания евразийских трансконтинентальных экономических осей освоения. При этом было отмечено, что лидирующее место в региональном развитии транспортных систем объективно принадлежит Китаю. В некоторых вопросах, заданных док- ладчику, прозвучали сомнения о целесообразности поддержки Россией новых евразийских транспортных коридоров в ущерб существующих. Однако докладчик выразил уверенность в том, что концепция «Новый шёлковый путь» не вступает в противоречие с Транссибом, наоборот, возможно их взаимодополнение в рамках стратегического объединения евразийского континентального пространства, что решит и некоторые геополитические проблемы. В связи с этим был также сделан вывод о необходимости активизировать развитие зоны Транссибирской магистрали посредством её преобразования в скоростной евразийский транспортный коридор.

А.В. Мошков (ТИГ ДВО РАН) в докладе «Основные типы ресурсных вертикально-интегрированных и сетевых территориально-производственных структур Дальнего Востока России» обратил внимание на перспективы развития структуры особых экономических зон Дальнего Востока в периоде до 2030 года. Докладчик выделил три типа зон опорного развития: 1) с преимущественно обрабатывающими сетевыми структурами и элементами добывающих вертикально-интегрированных структур; 2) с преимущественно обрабатывающими сетевыми структурами с транспортно-логистическими функциями; 3) с преимущественно добывающими вертикально-интегрированными структурами. Возможности развития региона докладчик в первую очередь связал с реализацией совокупности мер по привлечению инвестиций и осуществлением серьёзных проектов по модернизации производства и сферы услуг.

Доклад В.Т. Старожилова (ДВФУ, г. Владивосток) по проблеме районирования окраинно-континентальных ландшафтных геосистем отразил результаты многолетних авторских исследований, посвящённых геолого-географическому изучению и ландшафтному картографированию крупных региональных звеньев (Сихотэ-Алинского, Сахалинского, Камчат- 
ского, Анадырьского), расположенных в окраинно-континентальном ландшафтном поясе Тихоокеанской России.

Несомненный научный интерес вызвали теоретические исследования представителей Института экономических исследований ДВО РАН (г. Хабаровск) по вопросам междисциплинарного изучения пространственной организации экономики Дальнего Востока (А.Н. Демьяненко) и места новой экономической географии в пространственных исследованиях (Д.А. Изотов).

В рамках секции «Актуальные проблемы изучения природно-ресурсных факторов регионального развития» широко обсуждались вопросы функционирования приокеанических геосистем. Состояние растительных ресурсов морских побережий и островов Приморского края было рассмотрено в докладе А.Г. Киселевой. С.И. Коженкова проанализировала ресурсный потенциал макроводорослей российского материкового побережья Японского моря. Доклад И.М. Родниковой был посвящён вопросам мониторинга состояния лишайникового покрова на островах залива Петра Великого. Б.И. Пшеничников рассмотрел вопрос развития приокеанических геосистем юго-восточной части Приморья.

В ряде докладов были затронуты проблемы, связанные с лесными, биологическими и почвенными ресурсами, в том числе влияние на них техногенного фактора. В.И. Росликова осветила специфику почв урбанизированных ландшафтов на техногенных активных оползнях. Н.К. Гагарская представила результаты исследования по адаптации мелких млекопитающих к воздействию соединений тяжёлых металлов и галогенов в бассейне реки Рудной. Л.А. Майорова обратила внимание присутствующих на продуктивность хвойных лесов Приморского края. В докладе Р.А. Макаревич были рассмотрены источники негативного воздействия на природную среду при обогащении полиметалли- ческих руд. Ф.В. Скирин представил результаты лихеноиндикационных исследований в хвойных и хвойно-широколиственных лесах южного Сихотэ-Алиня (гора Литовка).

В нескольких докладах прозвучала тема геоморфологических исследований. Е.А. Мясников рассмотрел некоторые вопросы кадастроведения природноресурсного потенциала территории. В.В. Коробовым были рассмотрены геоморфологические условия развития рекреации на побережье артёмовского взморья.

В рамках секции «Экономикогеографические проблемы устойчивого социально-экономического развития регионов. Социальные и медикогеографические исследования условий и качества жизни населения» была также охвачена широкая тематика. Несколько докладов было посвящено проблемам и оценкам минерально-ресурсного потенциала территорий разного ранга. В докладе B.C. Батомункуева были рассматрены проблемы и перспективы освоения минерально-ресурсного потенциала Республики Бурятия. Докладчик на примере ГОК «Эрдэнет» также проанализировал влияние горнорудной промышленности на природные ландшафты Монголии. Г.Г. Ткаченко рассмотрел современное состояние и проблемы минерально-сырьевой базы Дальнего Востока и сделал прогнозные оценки основных показателей её развития. Докладчик также представил результаты оценки взаимодополняемости минерально-ресурсного потенциала субъектов Дальнего Востока.

Проблемам транспорта были посвящены доклады Р.В. Вахненко и Л.В. Горбатенко. В первом акцент был сделан на роли природно-ресурсного потенциала Тихоокеанской России в региональном развитии транспорта. Во втором докладе рассматривалась проблема судоходства и развития водных путей в бассейне реки Амур. 
Доклады В.Б. Калмановой «О системе информативных экологических критериев и показателей устойчивого развития городских территорий (на примере г. Биробиджан)» и Е.А. Ушакова, который проанализировал влияние природноресурсных факторов на развитие крупных городов азиатской части России, были связаны с проблемами развития урбанизированных территорий.

Проблематика части докладов имела ярко выраженную социально-экономическую направленность. Это доклады Е.В. Изергиной (об экономическом ущербе в субъектах ДВФО, связанном с нарушением здоровья населения), В.Л. Ушаковой (об особенностях межрегиональной миграции как фактора трансформации демографического и трудового потенциала в Приморском крае) и Т.А. Мирошниченко, которая исследовала перспективы электроснабжения населения за счёт солнечной энергии в Амурской области.

Рекреационную тематику представляли доклады А.А. Шабаева об экологических последствиях рекреационного использования некоторых памятников природы Приморского края, и З.И. Сидоркиной, которая выполнила исследование туристического кластера, рассматриваемого в качестве фактора регионального развития. Наконец, в докладе В.И. Преловского была сделана оценка ресурсного потенциала пляжного туризма на тихоокеанском побережье России. Экологическую проблематику представлял доклад Е.М. Климиной, в котором были показаны результаты оценки антропогенного воздействия на лесные геосистемы, выполненной на основе данных по отдельным муниципальным районам Дальнего Востока.

Завершилась конференция дискуссией, основу которой составило обсуждение кратких информационных отчётов председателей секций о ходе их работы, а также заместителя председателя оргкомитета А.В. Мошкова. В завершение конференции её председатель академик РАН П.Я. Бак- ланов обобщил ключевые оценки и выводы двух дней работы. Он выразил надежду, что в следующем году работа конференции будет ещё более насыщенной и плодотворной, а круг её участников расширится.

\section{Для цุитирования:}

Ткаченко Г.Г. Всероссийская научнопрактическая конференция «Природноресурсный потенциал регионального развития Азиатской России» // Регионалистика. 2014. Т. 1. № 2. С. 94-98.

For citing:

Tkachenko G.G. The All-Russian ScientificPractical Conference «Natural Resource Potential of Regional Development of the Asian Russia». Regionalistica [Regionalistics]. 2014. Vol. 1. No. 2. Pp. 94-98. (In Russian) 


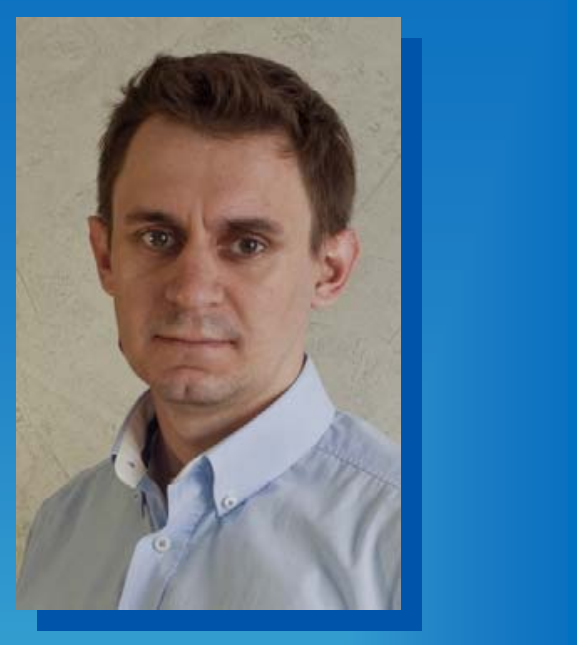

ИCAEB

Артём

Геннадьевич

Кандидат экономических наук, заведующий сектором

Институт экономических исследований ДВО РАН, ул. Тихоокеанская, 153, Хабаровск, Россия, 680042

\section{ISAEV \\ Artyom \\ Gennadyevich}

Ph.D. in economics, section head

Economic Research Institute FEB RAS, 153, Tikhookeanskaya Street, Khabarovsk, Russia, 680042

isaev@ecrin.ru

() Исаев А.Г., 2014

\section{ДЕВЯТЫЙ СОВМЕСТНЫЙ СЕМИНАР KIEP - ИЭИ ДВО РАН}

\section{$9^{\text {TH }}$ KIEP - ERI JOINT SEMINAR}

24-25 июня 2014 г. в г. Владивосток состоялся девятый ежегодный семинар, проводимый Институтом экономических исследований ДВО РАН (ИЭИ ДВО РАН) совместно с Корейским институтом международной экономической политики (KIEP). Главной темой двухдневного мероприятия, проводившегося в Президиуме ДВО РАН, послужила «Евразийская инициатива», предложенная в конце 2013 г. президентом Республики Корея Пак Кын Хе. С российской стороны в мероприятии приняли участие сотрудники ИЭИ ДВО РАН, включая Приморскую лабораторию института, а также представители Дальневосточного федерального университета.

\section{Сессия 1. «Стратегия развития Дальнего Востока администрации В.В. Путина: оценки и перспективы»}

Первая сессия была посвящена вопросам государственной экономической политики в отношении российского Дальнего Востока.

Доктор Че Сон Хун из КIEP представил доклад о перспективах сотрудничества Дальнего Востока и Республики Корея, а также поделился взглядами касательно геополитического и геоэкономического значения развития региона.

В совместном докладе академика РАН П.А. Минакира и доктора экономических наук О.М. Прокапало (ИЭИ ДВО РАН) «Стратегии и реальности: мечта о чуде» рассматривались вопросы программного развития Дальнего Востока, эффективности государственных капиталовложений в регионе [3]. Были отмечены проблемы, касающиеся нечёткого характера целей развития региона для федеральных властей. Общий вывод заключался в том, что для устойчивого развития региона требуются не столько масштабные инвестиции в транзитную инфраструктуру, так как они имеют кратковременный эффект, сколько выращивание эффективных эконо- 
мических институтов.

Теме государственных капиталовложений на Дальнем Востоке был посвящён доклад кандидата экономических наук А.Г. Исаева (ИЭИ ДВО РАН). По мнению докладчика, экономический эффект государственных капиталовложений можно разделить на две составляющие. Первая предполагает более существенное, но краткосрочное воздействие за счёт роста относительно трудоёмкой строительной отрасли. Вторая - расширение чрезвычайно капиталоинтенсивного транспортного сектора, имеющего, однако, относительно низкий мультипликативный эффект в экономике региона. Докладчиком была отмечена довольно низкая эффективность инвестиций из федерального бюджета в регионе в сравнении с их объёмом. В то же время нельзя недооценивать и их важность для процесса диверсификации экономической структуры Дальнего Востока, поскольку при их отсутствии перспективы экономического роста региона будут определяться только потенциалом добывающего и транспортного секторов экономики. Бизнес-структуры готовы инвестировать в развитие региона только при соответствующем инфраструктурном обеспечении инвестиционных проектов со стороны государства.

Наконец, в своём докладе доктор экономических наук С.Н. Найден (ИЭИ ДВО РАН) обратила внимание на важность развития на Дальнем Востоке человеческого капитала, повышения качества жизни, поскольку, несмотря на рост покупательной способности доходов населения региона по отношению к стоимости прожиточного минимума, эти показатели ниже, чем в среднем по России. По мнению выступавшей, для достижения целей социально-экономического развития региона необходима специальная программа, посвящённая развитию социального потенциала территории.

\section{Сессия 2. «Корейско- российская промышленная кооперация на Дальнем Востоке: транспорт и энергетика»}

Тематика второй сессии касалась вопросов промышленной кооперации Республики Корея и Российской Федерации на Дальнем Востоке. Если годом ранее обсуждались перспективы развития обрабатывающих отраслей [2], то в этот раз речь шла о кооперации в сфере транспорта и энергетики.

В докладе кандидата экономических наук А.Б. Бардаль (ИЭИ ДВО РАН) были затронуты перспективы сотрудничества в области транспорта в свете Евразийской инициативы. В частности, были рассмотрены вопросы развития транскорейской железнодорожной магистрали, использования Северного морского пути, а также проекты по созданию портовых комплексов в Приморском крае [1].

Кандидат экономических наук О.В. Дёмина (ИЭИ ДВО РАН) осветила вопросы экспортного потенциала России на рынке энергоресурсов стран СВА. Среди наиболее перспективных направлений сотрудничества были выделены долгосрочные контракты на поставку ресурсов, совместное строительство инфраструктурных объектов и совместные научнотехнические разработки в области энергетики. Последнее направление было обозначено как наиболее важное, поскольку в перспективе на передний план выдвигается проблема технологического лидерства в энергетическом секторе.

Оживлённый интерес вызвал доклад доктора На Хысын (Корейский институт железнодорожных исследований), в котором в большей степени рассматривались технологические вопросы, касающиеся вариантов решения логистической проблемы, связанной с различиями в ширине железнодорожной колеи в Европе, России и 
Республике Корея. Докладчиком были продемонстрированы различные варианты технологического решения данной проблемы, разрабатываемые в его институте.

\section{Сессия 3. «Евразийская}

\section{экономическая интеграция и Евразийская инициатива»}

В рамках третьей сессии рассматривались вопросы Евразийской экономической интеграции.

Доктор Хан Хон Ёль из университета Ханьян в своём выступлении дал оценку политике расширения ЕврАзЭС и её перспектив через призму структурных изменений в мировой экономике. В докладе было отмечено, что для стран бывшего СССР, несмотря на стремление к экономической интеграции высокого уровня, характерна достаточно низкая доля обрабатывающей промышленности и невысокая степень разделения труда. Поэтому задачей продвижения ЕврАзЭС становится обеспечение дополняемости по отношению к промышленной структуре всего ATP.

Доктор Чжон Е Чхон (KIEP) попытался сопоставить и сравнить политику продвижения Российской Федерации в Тихоокеанский регион и Евразийскую инициативу президента Республики Корея Пак Кын Хе. Докладчик обратил внимание на то, что, несмотря на состоявшуюся торговую интеграцию между российским Дальним Востоком и странами СВА, наблюдается определённая пассивность российской политики с точки зрения привлечения иностранного капитала в регион, в особенности для целей развития местного производства и его инфраструктуры.

Похожим проблемам уделил внимание в своём докладе доктор экономических наук Ю.Д. Шмидт (ИЭИ ДВО РАН). Докладчик особо выделил тот факт, что иностранный капитал крайне осторожно выбирает сферы своего приложения в даль- невосточной экономике, отдавая предпочтение ресурсоэксплуатирующим проектам и оставляя без внимания предложения к сотрудничеству в обрабатывающих и сервисных отраслях. В этой ситуации евразийские интеграционные процессы должны способствовать расширению рынков сбыта промышленной продукции России, накоплению инвестиционных ресурсов для дальнейшего инновационного развития.

\section{Сессия 4. «Мир и кооперация в Северо-восточной Азии и Евразийская инициатива»}

Четвёртая сессия имела ярко выраженную геополитическую направленность и была посвящена вопросам мирного урегулирования конфликтов в Северовосточной Азии, а также вопросам кооперации.

Доктор политических наук С.В. Севастьянов (ДВФУ) в своём докладе «Евразийский проект президента Владимира Путина и Евразийская инициатива президента Пак Кын Хе: насколько сильна синергия?» отметил, что корейская инициатива пытается пробиться к жизни на фоне углубляющихся связей между Россией и КНР, включающих инициативу этих стран по созданию системы кооперативной безопасности. Докладчик заключил, что для обеспечения поступательного движения в реализации международной политики России и Республике Корея необходимо будет учитывать интересы других ведущих региональных держав.

Доклад доктора Ли Намчжу (Университет Сун Кён Хо) был посвящён многостороннему сотрудничеству в сфере безопасности в Северо-Восточной Азии. В нём было отмечено, что, несмотря на очень тесную экономическую кооперацию, в регионе имеется множество разногласий по разным политическим вопросам, в особенности по территориальным спорам.

В выступлении доктора Ким Тхэхён 
из Университета Сунсил был затронут ещё один важный геополитический аспект: политика США в регионе и её влияние на перспективы Евразийской инициативы.

Кандидат экономических наук В.В. Кучук (Минвостокразвития) особо подчеркнул необходимость учитывать при реализации Евразийской инициативы мнений и действий такого важного регионального игрока как Китай, имеющего огромное влияние не только в АзиатскоТихоокеанском регионе, но и в Центральной Азии.

Кандидат политических наук А.Л. Лукин (ДВФУ) также отметил, что при осуществлении Евразийской инициативы, а также в вопросе объединения, Республика Корея должна учитывать интересы КНДР.

Общим итогом сессии послужил довольно сдержанный вывод о перспективах Евразийской инициативы ввиду изменения баланса сил в регионе и ограниченных дипломатических ресурсов Кореи.

\section{Сессия 5. «Евразийская инициатива и Корейский полуостров»}

Заключительная пятая сессия была посвящена перспективам Корейского полуострова в свете реализации Евразийской инициативы.

Доклад доктора Бэк Джун Ки (Университета Ханшин) затрагивал северокорейскую ядерную проблему, а также стратегическую роль России в её разрешении и поддержании стабильности и мирных инициатив на Корейском полуострове. Было отмечено, что в отличие от Европы, в регионе АТР не существует многостороннего механизма сотрудничества в области безопасности, а та система, которая существует, сильно отстает по своему уровню от экономического развития, от системы торговли и обмена в регионе. Создание евразийской системы безопасности - одна из ключевых задач регионального развития.

Кандидат экономических наук Д.В. Суслов (ИЭИ ДВО РАН) в своём докладе рассмотрел перспективы двустороннего российско-корейского сотрудничества, касающиеся развития железнодорожной сети, морских портов и логистических центров, а также совместных проектов в промышленности. По мнению докладчика, в развитии сотрудничества и урегулировании корейской проблемы широкие возможности предоставляет проект особой экономической зоны в дельте реки Туманная. Для реализации данного проекта необходимо сформировать взаимодополняющую схему трёхстороннего сотрудничества, которая бы предполагала совместное использование факторов производства: трудовых ресурсов КНДР, природных ресурсы России и южнокорейского капитала.

Также на семинаре выступил заместитель министра РФ по развитию Дальнего Востока М.Л. Шерейкин. В своём докладе он разъяснил новую концепцию развития Дальнего Востока, заключающуюся в формировании территорий опережающего роста. Касательно проблем развития региона замминистра высказал интересное, но небесспорное суждение о том, что одной из главных причин отставания социально-экономического развития Дальнего Востока является недостаточная мотивация локальных экономических агентов, будь то бизнес или органы власти, ввиду значительной государственной поддержки, оказываемой региону в последнее десятилетие. В качестве примеров, описывающих обратную ситуацию, М.Л. Шерейкин привёл Республику Татарстан и Ульяновскую область, в которых, по его мнению, активность местных органов власти на рынке капитала способствовала устойчивому экономическому росту этих территорий.

Подводя итоги семинара, его участники отметили важность совместных экономических и политических усилий двух стран в сфере международной кооперации. Такие действия влекут за собой не только 
реализацию совместных проектов, но и дают повод для дальнейших плодотворных встреч в рамках сотрудничества двух институтов.

По результатам семинара был издан сборник докладов на корейском и русском языках [4].

\section{Список литературы}

1. Бардаль А.Б. Транспортный комплекс региона в условиях вступления России в ВТО: Дальний Восток // Пространственная экономика. 2014. № 1. С. 153-175.

2. Исаев А.Г. Российские планы регионального развития и международная кооперация // Пространственная экономика. 2013. № 4. C. $184-186$.

3. Минакир П.А., Прокапало О.М. Государственная программа РФ «Социальноэкономическое развитие Дальнего Востока и Байкальского региона» // Пространственная экономика. 2013. № 1. С. 103-122.

4. Korea-Russia Cooperation in the Far East in Light of the Eurasia Initiative. 9th KIEP-ERI Joint Seminar. KIEP, 2014. 296 p.

\section{References}

1. Bardal A.B. Transport Complex of the Region under Russia's Accession to the WTO: the Russian Far East. Prostranstvennaya economika [Spatial Economics]. 2014. No. 1. Pp. 153-175. (In Russian)

2. Isaev A.G. Russian Plans of Regional Development and International Cooperation. Prostranstvennaya economika [Spatial Economics]. 2013. No. 4. Pp. 184-186. (In Russian)

3. Minakir P.A., Prokapalo O.M. The Russian Federation State Program «Socio-Economic Development of the Far East and the Baikal Region». Prostranstvennaya economika [Spatial Economics]. 2013. No. 1. Pp. 103-122. (In Russian)

4. Korea-Russia Cooperation in the Far East in Light of the Eurasia Initiative. 9th KIEP-ERI Joint Seminar. KIEP, 2014. 296 p.

\section{Для ичитирования:}

Исаев А.Г. Девятый совместный семинар KIEP - ИЭИ ДВО РАН // Регионалистика. 2014. T. 1. № 2. C. 99-103.

For citing:

Isaev A.G. $9^{\text {th }}$ KIEP - ERI Joint Seminar. Regionalistica [Regionalistics]. 2014. Vol. 1. No. 2. Pp. 99-103. (In Russian) 


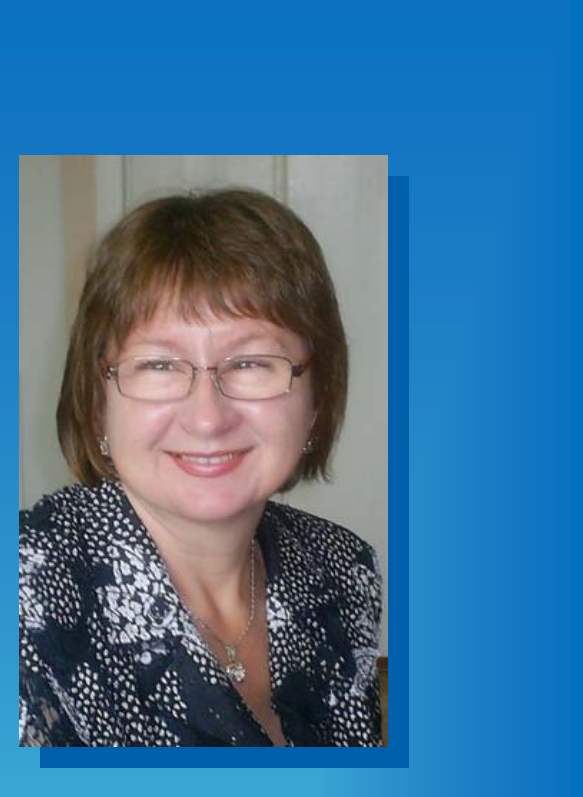

ЛОМАКИНА

Наталья

Валентиновна

Доктор экономических наук, заведующая сектором

Институт экономических исследований ДВО РАН, ул. Тихоокеанская, 153, Хабаровск, Россия, 680042

\section{LOMAKINA \\ Natalia \\ Valentinovna}

Doctor of economics, section head

Economic Research Institute FEB RAS,

153, Tikhookeanskaya Street,

Khabarovsk, Russia, 680042

lomakina@ecrin.ru

() Ломакина Н.В., 2014

\section{NOT ONLY GOLD... (SHORT NOTES ABOUT G. F. SKLYAROVA'S BOOK «RAW MINERAL SECTOR OF NONMETALS OF THE FAR EAST AND ITS ROLE FOR REGION ECONOMY»)}

Вопрос взаимосвязи между развитием Дальневосточного региона и освоением его минеральных ресурсов уже давно «на слуху» и стал привычным. При этом большинство работ, описывающих современное развитие минерального сектора региона и обосновывающих его перспективы (включая и работы автора этих строк $[1 ; 2])$, посвящено освоению высоколиквидных ресурсов - алмазов, золота, серебра, отдельных видов цветных и чёрных металлов. Однако ресурсная «палитра» Дальнего Востока значительно богаче и разнообразнее. Поэтому появление работ, посвящённых проблемам и возможностям использования всего спектра минеральных ресурсов региона, весьма актуально.

Один из таких трудов был издан в 2013 г. в Хабаровске. Это книга кандидата геолого-минералогических наук, старшего научного сотрудника лаборатории стратегии освоения минеральных ресурсов Института горного дела ДВО РАН Галины Федоровны Скляровой «Минерально-сырьевой сектор неметаллов Дальнего Востока и его роль для экономики региона» [3]. Как отмечает автор, неметаллические полезные ископаемые (НПИ) - одна из самых распространённых природных групп, включающая более 150 видов минерального сырья, их практическая и стратегическая значимость определяется широкомасштабным и многоцелевым использованием в различных отраслях экономики. Более того, «промышленное использование неметаллов рассматривается как показатель уровня социально-экономического развития страны, обеспечения её сырьевой, продовольственной 
и экологической безопасности». Согласно данным, приведённым в рецензируемой работе, в России на долю неметаллов приходится $60-65 \%$ суммарной годовой стоимости всего добытого минерального сырья. При этом, несмотря на достаточно высокую экспортную составляющую (по апатиту, асбесту, калийным солям и пр.), в стране наблюдается критическая зависимость (на 60-90\%) от импорта по ряду неметаллов (бентониты, барит, каолин, кристаллический графит и др.) [3, с. 6]. Поэтому, конечно, рассмотрение ресурсных возможностей развития минеральносырьевого сектора неметаллов в одном из крупных макрорегионов страны - Дальневосточном - является важным и актуальным. Эти вопросы, собственно, и составляют основной предмет рассматриваемой работы.

По Дальнему Востоку накоплен обширный фактический материал по месторождениям неметаллических полезных ископаемых, в том числе и благодаря усилиям такого известного специалиста, как Г.Ф. Склярова. В своей книге она рассматривает в основном ресурсы южной части региона, к важнейшим и специфичным относя: алуниты (Хабаровский край), апатиты (Амурская область, Хабаровский край), фосфориты (Хабаровский край, Еврейская $\mathrm{AO})$, магнезиты (Еврейская АО, Приморский край), бруситы (Еврейская АО), высокоглинозёмистое сырьё (Хабаровский и Приморский края, Еврейская АО), графиты (Еврейская АО, Приморский край), борные руды и флюорит (Приморский край), карбонатные породы и цеолиты (практически по всем регионам).

Среди главных задач книги обозначены оценка состояния минеральносырьевой базы неметаллических полезных ископаемых Дальнего Востока и их характеристика с позиций многоцелевого применения в важнейших отраслевых комплексах региона. Соответственно этим задачам выстроена и структура книги. Основной текст объёмом около 300 страниц разбит на три целевых раздела, описывающих в целом состояние минеральносырьевой базы неметаллических полезных ископаемых Дальнего Востока (раздел 2), перспективы их комплексного многоцелевого использования (раздел 4), а также детальные характеристики НПИ Дальнего Востока с позиций их многоцелевого применения (раздел 3).

Последний из названных разделов является базовым, составляя, по сути, основное содержание книги. Ресурсные и технологические возможности применения неметаллических полезных ископаемых Дальнего Востока рассмотрены для целого ряда отраслевых и многоотраслевых комплексов: агропромышленного, металлургического, топливно-энергетического, химико-лесного, строительного, экологического и др. Для каждого из названных комплексов рассмотрены важнейшие виды полезных ископаемых с характеристикой их физико-химических свойств, оценкой размещения месторождений, запасов и прогнозных ресурсов, степени их изученности или освоенности, описанием возможных технологий получения продукции.

Представленный в книге фактический материал, накопленный автором за десятилетия исследовательской работы, содержит сведения по месторождениям и объектам, наиболее перспективным в ближайшем будущем - эксплуатирующимся, разведанным, рекомендуемым для постановки разведочных или поисковооценочных работ. Оценки и рекомендации автора базируются на информации действующих предприятий, содержащихся в ТЭО расчётных показателях предполагаемых предприятий, а также показателяханалогах с учётом имеющегося мирового и «локального» опыта.

Безусловно, такая работа может оказаться весьма полезной и для органов регионального управления, и для бизнеса (в том числе и малого).

Однако в ходе знакомства с книгой 
не обошлось и без некоторых вопросов. Самый большой вопрос связан с названием работы, поскольку сложно согласиться с присутствием в нём столь обязывающей концовки: «... роль для экономики региона». Экономические оценки, стоимостные показатели и сравнения, к большому сожалению, практически отсутствуют. А отдельные имеющиеся в работе цифры лишь подчёркивают наличие означенной лакуны. Так, например, приводятся показатели геолого-экономической оценки Бираканского месторождения талька, выполненной институтом «Хабаровскпромпроект» ... в 1964 г. [3, с. 228].

Представляется, что более «скромное», но соответствующее содержанию название нисколько бы не уменьшило ценность рецензируемой работы, насыщенной богатым фактическим материалом.

\section{Список литературы}

1. Ломакина Н.В. Минерально-сырьевой комплекс Дальнего Востока России: потенциал развития / отв. ред. П.А. Минакир; Рос. Акад. Наук, Дальневост. отд-ние, Ин-т экон. исследований. Хабаровск: РИОТИП, 2009. 240 с.

2. Ломакина Н.В., Антонова Н.Е. Современная система природопользования Дальнего Востока: новые тенденции и оценки // Пространственная экономика. 2013. № 3. С. 89107.

3. Склярова Г.Ф. Минерально-сырьевой сектор неметаллов Дальнего Востока и его роль для экономики региона. Хабаровск, 2013. $288 \mathrm{c}$.

\section{References}

1. Lomakina N.V. The Mineral Resources Sector of the Russian Far East: the Development potential. Ed. by P.A. Minakir. Khabarovsk, 2009. 240 p. (In Russian)

2. Lomakina N.V., Antonova N.E. Modern System of Nature Management of the Russian Far East: New Tendencies and Estimates. Prostranstvennaya economika [Spatial Economics]. 2013. No. 3. Pp. 89-107. (In Russian)
3. Sklyarova G.F. Raw Mineral Sector of Nonmetals of the Far East and Its Role for Region Economy. Khabarovsk, 2013. 288 p. (In Russian)

\section{Для цичтирования:}

Ломакина Н.В. Не золотом единым... (Краткие заметки о книге Г.Ф. Скляровой «Минерально-сырьевой сектор неметаллов Дальнего Востока и его роль для экономики региона») // Регионалистика. 2014. Т. 1. № 2. C. 104-106.

\section{For citing:}

Lomakina N.V. Not Only Gold... (Short Notes about G.F. Sklyarova's Book «Raw Mineral Sector of Nonmetals of the Far East and Its Role for Region Economy»). Regionalistica [Regionalistics]. 2014. Vol. 1. No. 2. Pp. 104-106. (In Russian) 


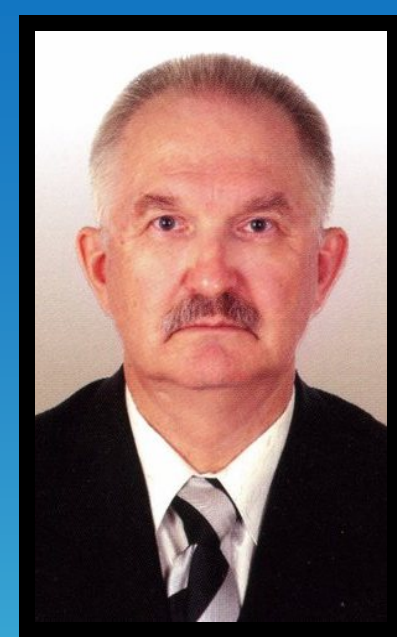

$1940-2014$ 


\section{Regfonalistica}

\section{[Regionalistios] \\ 2014 Vol. 1 NO.2 \\ Electronic scientific journal \\ regionalistica.org \\ ISSN 2313-0881}

The journal's periodicity:

6 times a year

\section{Founder:}

Federal State Budgetary

Scientific Institution

The Economic Research Institute,

Far-Eastern Branch of

the Russian Academy of Sciences

(Khabarovsk)

Registered by the Federal Service for Supervision of Communications, Information Technology, and Mass Media. Registration certificate Эл № ФС77-57151 of March 11, 2014.

\section{a}

The authors are fully responsible for the compilation and presentation of information contained in their papers. Authors' views may not reflect the Editors' point of view. Not part of the Journal materials can be reprinted without permission from the Editors.

\section{-}

\section{Contacts:}

Economic Research Institute FEB RAS, 153, Tikhookeanskaya Street, Khabarovsk, Russia, 680042

Phone: +7 (4212) 225-404

E-mail: regionalistica@ecrin.ru

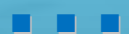

Design, editing \& making-up: V.N. Ukrainsky

Petrus Plancius's map (1594) is used in design of a cover

\section{The Editorial Staff}

\section{Editor-in-Chief: A.N. Demyanenko, Doctor of Geography, Professor}

A.V. Moshkov, Doctor of Geography (Vladivostok, Russia)

S.N. Nayden, Doctor of Economics (Khabarovsk, Russia)

O.M. Prokapalo, Doctor of Economics (Deputy Editor-in-Chief, Khabarovsk, Russia)

Yu.D. Shmidt, Doctor of Economics (Vladivostok, Russia)

Tsuneo Akaha, Professor (Monterey, USA)

Vincent F. Gallucci, Professor (Seattle, USA)

A.P. Goryunov, Ph.D. in economics (Khabarovsk, Russia)

A.A. Kireev, Ph.D. in political science (Vladivostok, Russia)

V.S. Kuznetsov, Ph.D. in economics (Vladivostok, Russia)

L.A. Samokhina (Khabarovsk, Russia)

V.N. Ukrainsky, Ph.D. in economics (Managing Editor, Khabarovsk, Russia)

\section{0}

\section{The Editorial Board}

Chairman: P.A. Minakir, Academician RAS

V.A. Kryukov, Corresponding Member RAS (Novosibirsk, Russia) V.N. Lazhentsev, Corresponding Member RAS (Syktyvkar, Russia) V.I. Suslov, Corresponding Member RAS (Novosibirsk, Russia) A.S. Shelepa, Corresponding Member RAAS (Khabarovsk, Russia) S.D. Valentey, Doctor of Economics (Moscow, Russia) N.V. Galtseva, Doctor of Economics (Magadan, Russia) S.V. Kuznetsov, Doctor of Economics (Saint-Petersburg, Russia) Yu.G. Lavrikova, Doctor of Economics (Yekaterinburg, Russia) A.V. Ostrovsky, Doctor of Economics (Moscow, Russia) V.E. Rokhchin, Doctor of Economics (Saint-Petersburg, Russia) A.N. Shvetsov, Doctor of Economics (Moscow, Russia) A.M. Shkurkin, Doctor of Philosophy (Khabarovsk, Russia) 